\title{
Hungarian Elements in Selected Piano Compositions of Liszt, Dohnanyi, Bartok, and Kodaly
}

Helga Scheibert

Follow this and additional works at: https://researchrepository.wvu.edu/etd

\section{Recommended Citation}

Scheibert, Helga, "Hungarian Elements in Selected Piano Compositions of Liszt, Dohnanyi, Bartok, and Kodaly" (2017). Graduate Theses, Dissertations, and Problem Reports. 6579.

https://researchrepository.wvu.edu/etd/6579

This Dissertation is protected by copyright and/or related rights. It has been brought to you by the The Research Repository @ WVU with permission from the rights-holder(s). You are free to use this Dissertation in any way that is permitted by the copyright and related rights legislation that applies to your use. For other uses you must obtain permission from the rights-holder(s) directly, unless additional rights are indicated by a Creative Commons license in the record and/ or on the work itself. This Dissertation has been accepted for inclusion in WVU Graduate Theses, Dissertations, and Problem Reports collection by an authorized administrator of The Research Repository @ WVU.

For more information, please contact researchrepository@mail.wvu.edu. 


\title{
Hungarian Elements in Selected Piano Compositions of Liszt, Dohnányi, Bartók, and Kodály
}

\author{
Helga Scheibert \\ Research Project submitted to the College of Creative Arts \\ at West Virginia University \\ in partial fulfillment of the requirements for the degree \\ Doctor of Musical Arts \\ in Piano Performance \\ Peter Amstutz, DMA, Chair and Research Advisor \\ Cynthia Anderson, MM, Director of Graduate Studies \\ James Miltenberger, DMA \\ William Haller, DMA \\ John Goldwasser, PhD
}

School of Music

Morgantown, West Virginia

2017

Keywords: Hungarian, Folk Song, Liszt, Dohnányi, Bartók, Kodály

Copyright 2017 [Helga Scheibert] 


\section{ABSTRACT \\ Hungarian Elements in the Piano Music of Liszt, Dohnányi, Bartók and Kodály}

\section{Helga Scheibert}

This paper begins by discussing Hungarian folk music, clarifying the difference between folk and art music. There is also a distinction to make between Hungarian peasant music, with its historical origins and five-tone scale, and Gypsy music, with its Oriental scales that played a major role in Liszt's music. Béla Bartók and Zoltán Kodály are the two leading researchers who studied Hungarian musical folklore. The contributions of those two composers, along with those of Liszt and Dohnányi, are discussed in individual chapters, with emphasis on selected works.

Many composers intended to write in Hungarian style; but Liszt created his own "Hungarian" style in the Rhapsodies, which are primarily influenced by Gypsy style. The sounds of Hungarian instruments play an important role in Liszt's music; for example, evocations of the cimbalom appear in many of his works. The structure, ornamentation, and rhythm of Liszt's Hungarian Rhapsody No. 15 are discussed.

Dohnányi also made important contributions to Hungarian music. His heritage is on display in the Variations on a Hungarian Folk Song, Op. 29.

Bartók was hugely important as an ethnomusicologist, composer and also pianist. Three of his solo piano works are discussed: Romanian Folk Dances, Three Hungarian Folk Songs from Csik, and Sonatina. His compositional style evolved over time, but he still incorporated folk music in the Piano Concerto No. 3.

Like Bartók, Kodály was both a researcher and also a composer. His Dances of Marosszék provide an idiomatically Hungarian portrait.

The concluding chapter briefly compares the ways these four composers incorporated Hungarian elements in their music. 


\section{Table of Contents}

$\begin{array}{lll}\text { Chapter I Statement of topic. } & 1\end{array}$

$\begin{array}{llr}\text { Chapter II } & \text { Review of existing literature } & 6\end{array}$

Chapter III Hungarian folk music discussions, origin, and analysis $\quad 10$

$\begin{array}{ll}\text { Hungarian instruments } & 19\end{array}$

$\begin{array}{ll}\text { Gypsy music (history and characteristics) } & 21\end{array}$

$\begin{array}{lll}\text { Chapter IV Liszt } & 29\end{array}$

About the composer $\quad 29$

The Hungarian Rhapsodies, highlighting the 15th Rhapsody 31

$\begin{array}{lll}\text { Chapter V Dohnányi } & 47\end{array}$

About the composer $\quad 47$

Variations on a Hungarian Folk Song, Op. 29

$\begin{array}{lll}\text { Chapter VI Bartók } & 56\end{array}$

About the composer $\quad 56$

$\begin{array}{ll}\text { Sonatina } & 61\end{array}$

Romanian Folk Dances $\quad 68$

Three Hungarian Folk Songs from Csík

Third Piano Concerto $\quad 87$

$\begin{array}{lll}\text { Chapter VII Kodály } & 100\end{array}$

$\begin{array}{ll}\text { About the composer } & 100\end{array}$

Dances of Marosszék 102

$\begin{array}{lll}\text { Chapter VIII Conclusion } & 111\end{array}$

$\begin{array}{ll}\text { Bibliography } & 116\end{array}$ 


\section{List of Musical Figures}

Figure 1. Pentatonic Scale 14

Figure 2. Z. Kodály, Székely tune from Marostorda 15

Figure 3. L. Lajtha, Folk Song from Transylvania 18

Figure 4. Bakázo $\quad 24$

Figure 5. Ég a Kunyhó ("The Hut is Burning") 25

Figure 6. Csak Egy Szép Kislány Van a Világon ("There is Only One Pretty Girl”) 26

Figure 7. Szeretnék Szántani ("I Should Love to Plough") 27

Figure 8. Brahms, Hungarian Dances for Orchestra No. $10 \quad 28$

Figure 9. Ungar Scale

Figure 10. F. Liszt, Hungarian Rhapsody No. 8, m. 40

Figure 11. F. Liszt, Hungarian Rhapsody No. 15, mm. 1-13 40

Figure 12. F. Liszt, Hungarian Rhapsody No. 15, mm. 16-19 41

Figure 13. Rákóczi Nota, The Kuruc-fourth

Figure 14. F. Liszt, Kuruc-fourths in Hungarian Rhapsody No. 15. mm. 33-37 42

Figure 15. F. Liszt, Hungarian Rhapsody No. 15, mm. 90-97 44

Figure 16. F. Liszt, Hungarian Rhapsody No. 15, mm. 166-194 45

Figure 17. E. Dohnányi, Variations on a Hungarian Folk Song, mm. 1-6 50

Figure 18. Szivárvány Havasán ("On the Mountain Top”) 51

Figure 19. E. Dohnányi, Variations on a Hungarian Folk Song,
Variation III, mm. 1-6

Figure 20. E. Dohnányi, Variations on a Hungarian Folk Song,

Variation V, mm. 1-4 53

Figure 21. E. Dohnányi, Variations on a Hungarian Folk Song,
Variation IX, mm. 35-57

Figure 22. E. Dohnányi, Variations on a Hungarian Folk Song,

Figure 23. B. Bartók, "Evening in Transylvania" No. 5 from Ten Easy Pieces for Piano

Figure 24. B. Bartók, 1st Movement from Sonatina, mm. 1-2 62

Figure 25. B. Bartók, 1st Movement from Sonatina, segment A, mm. 1-4 63

Figure 26. B. Bartók, 1st Movement from Sonatina, segment B. mm. 21-26 64

Figure 27. B. Bartók, 1st Movement from Sonatina, mm. 61-66 64

Figure 28. B. Bartók, 2nd Movement from Sonatina, mm. 1-5 65

Figure 29. B. Bartók, 3rd Movement from Sonatina, segment A, mm. 1-15 66

Figure 30, B. Bartók, 3rd Movement from Sonatina, segment B, 37-48 66

Figure 31. B. Bartók 3rd Movement from Sonatina, mm. 76-102 67

Figure 32. B. Bartók, "Joc cu Bâta” from Romanian Dances, mm. 1-10 70

Figure 33. B. Bartók, "Brâul” from Romanian Dances, mm. 1-10 70

Figure 34. B. Bartók, "Pe Loc" from Romanian Dances, 1-12 71

Figure 35. B. Bartók, "Buciumeana” from Romanian Dances, mm. 13-18 72

iv 
Figure 36. B. Bartók, "Poarca Româneasca” from Romanian Dances, mm. 1-10 73

Figure 37. B. Bartók, "Măruntel" from Romanian Dances, mm. 45-62 74

Figure 38. Röpülj Páva Röpülj ("Fly Peacock Fly"), folk song collected by Kodály 76

Figure 39. Bartók's sketch of Romlott Testem from Csíkrákos 1907

Figure 40. B. Bartók First String Quartet $\quad 78$

Figure 41. B. Bartók, Romlott Testem 79

Figure 42. B. Bartók, "The Peacock" from Three Hungarian Folk Songs, mm. 1-8 79

Figure 43. B. Bartók, "The Peacock” from Three Hungarian Folk Songs, mm. 14-16 80

Figure 44. B. Bartók, "The Peacock" from Three Hungarian Folk Songs, mm. 9-16 81

Figure 45. Jánoshidi Vásártéren ("At the Jánoshida Fairground") 82

Figure 46. B. Bartók "At the Jánoshida Fairground" from Three Hungarian Folk Songs, mm. 1-16. 83

Figure 47. B. Bartók "White Lily" from Three Hungarian Folk Songs, mm. 1-9 84

Figure 48. B. Bartók Ha Kimegyek Arra a Magas Tetöre ("If I Go Up to the High Mountains") 85

Figure 49. B. Bartók, Eight Hungarian Folk Songs for Voice and Piano, No. 5 mm. 1-8 86

Figure 50. B, Bartók, Piano Concerto No. 3, 1st Movement, mm. 1-7 91

Figure 51. B. Bartók, Piano Concerto No. 3, 1st Movement, mm. 13-19 92

Figure 52. B. Bartók Piano Concerto No. 3, 3rd Movement, main theme 97

Figure 53. Original melody collected by Kodály in Csik county in $1910 \quad 104$

Figure 54. Z. Kodály, Dances of Marosszék, mm. 1-13 104

Figure 55. Original melody first recorded by Béla Vikár 105

Figure 56. Z. Kodály, Dances of Marosszék, mm. 18-33 105

Figure 57. Original melody transcribed by Kodály 107

Figure 58. Z. Kodály, Dances of Marosszék, mm. 100-109 107

Figure 59. Original melody collected and recorded by Kodály in $1912 \quad 108$

Figure 60. Z. Kodály Dances of Marosszék, mm. 174-193 109 


\section{Chapter I}

\section{Statement of topic}

The subject of my research is "Hungarian Elements in Selected Piano Compositions of

Liszt, Dohnányi, Bartók and Kodály.” Among the reasons for choosing this topic are that I love these pieces and that I was born to a Hungarian family in Transylvania, a region of Romania with a large ethnic Hungarian population.

I feel that the Hungarian folk art and traditions in Transylvania are among our greatest cultural treasures. During my high-school years, I attended folk-art summer camps and gained a great appreciation for my cultural heritage. As a native speaker of Hungarian, I can appreciate the folk texts and traditional references that my chosen composers used and I can also explore the Hungarian-language scholarly sources about Hungarian music and folk arts that are available here in the United States.

Among the pieces I discuss is Dances of Marosszék, by Zoltán Kodály (1882-1967). The Marosszék region, today called Mures County, was my childhood home. I consider it a personal honor to research, explore, and write about this piece.

It is also to my great benefit that most of the chosen works studied for this project are in my performing repertoire. These pieces are very dear to me. In 2010, I performed Three Hungarian Folk Songs from Csik, one of my favorite works by Béla Bartók (1881-1945), in New Brunswick, New Jersey, for the Hungarian event entitled "15th March Hungarian Revolution of 1848." March 15 is one of the biggest national Hungarian holidays and 200 
people were present at this event, in part to hear the beautiful folk music from my homeland. In 2014, my first DMA piano recital at WVU included only Hungarian compositions, by Bartók, Kodály, Ernö Dohnányi (1877-1960) and Franz Liszt (1811-1886); that same year, I also performed these pieces in Gainesville, Florida. The Cleveland (Ohio) Hungarian Heritage Society honored me with an invitation to present a concert entitled "From Hungarian Melodies to Classical Masterpieces: Liszt, Bartók, Schubert, Dohnányi and Chopin.” This recital was the opening event of their Fall 2015 season series.

I gained a lot of knowledge about these composers and their music by preparing for these recitals. Certainly it was a wonderful experience to share and to be able to touch the listeners' ears and hearts with this special music.

The project begins by focusing on Hungarian folk music, clarifying the difference between folk music and art music. Béla Bartók and Zoltán Kodály are the two leading personalities who studied Hungarian musical folklore. Then we take a closer look at Hungarian peasant music, explaining its origins and its use of the five-tone scale. Hungarian instruments also exert an important influence on this music; for example, the sound of the cimbalom is the source of many colorful moments in Liszt's music. Focusing on gypsy music was my next step, investigating their music's originality. The gypsy scale plays a major role in Liszt's music and it is interesting to note that these scales have an Oriental flavor.

The fourth chapter presents a short biography of Liszt and discusses how he created his own "Hungarian" style in the Rhapsodies. We consider examples of Hungarian elements in Liszt's music, as seen in such works as the Dante Symphony and the Grand Gallop Chromatique. This chapter focuses primarily on the Hungarian Rhapsody No. 15, discussing its 
structure, ornamentation, and rhythm.

Dohnányi also made very important contributions to Hungarian music. It is fascinating to notice his direct connections with Liszt, Bartók and Kodály: István Thoman, Dohnányi’s piano teacher, was a pupil of Liszt; perhaps this is the main reason why Dohnányi's music was so profoundly influenced by that of Liszt. In 1902, Bartók began studying with Dohnányi and the two became lifelong friends. Later on, Bartók became a colleague of Kodály's at the Liszt Academy in Budapest.

The Dohnányi work which I have selected is the Variations on a Hungarian Folk Song, Op. 29, which clearly reflects the composer's Hungarian heritage. The main theme is based on a pentatonic scale, but the tune is actually not a familiar folk song. In each variation we observe how the main theme is transformed and note what other Hungarian elements Dohnányi employs; for example, in the third variation, Dohnányi imitates the characteristic sound of the cimbalom.

In the next chapter we consider several piano works of Bartók. The Romanian Folk Dances set contains six individual dances: "Dance with Sticks," "Waistband Dance," "Stamping Dance," "Hornpipe Dance," "Romanian Polka," and "Quick Dance." Each of these dances comes originally from Transylvania. We pay special attention here to rhythm, melody and character. Another Hungarian element that appears in this set is the imitation of a shepherd's flute in the third dance.

The Sonatina, which Bartók originally entitled "Sonatina on Romanian Folk Tunes," has three parts: "Bagpipers," "Bear Dance," and "Finale." The piece employs five folk tunes: two in the first movement, one in the second and two in the last. Here I investigate the character, 
rhythms, and other special Hungarian sound effects, such as the imitation of cimbalom and violin.

Another piece that is worthy of study is Three Hungarian Folk Songs from Csik. The first song, in B Dorian mode, is called "The Peacock," traditionally a symbol of freedom and salvation. "At the Janoshida Fairground" has many changing meters and complex rhythms; it is written in F\# Aeolian. The last song, entitled "White Lily," is also based on F\# Aeolian.

Bartók's compositional style changed in his later output; but he still incorporated folk music in the Piano Concerto No. 3. This concerto reveals his ongoing connection with, and return to, the beginning of his activities, when he was an ethnomusicologist; but it is also a turning back to Neoclassicism and traditionalism. The main melody in the first movement is heavily ornamented. The whole movement is centered primarily in E Mixolydian, with simpler, more tertian harmonies than we find in his first two piano concertos. The second movement displays a unique beauty: The piano and orchestra alternate peacefully, the "night music" is bright and cheerful, and the result is profound inner contentment. The energy of the third movement, “Allegro Vivace,” reminds me of Bartók’s “Allegro Barbaro.” It is vivid and full of life, with a distinctive Hungarian folk rhythm: short-long, long-short.

The next chapter focuses on Kodály and his Dances of Marosszék. Here we discuss the composer's ethnomusicological activities. Then we look at how he incorporated folk material in Dances of Marosszék. Melodies in this piece come from two main sources: instrumental dance music from Transylvania and vocal melodies from about $1680{ }^{1}$

In the conclusion we compare and discuss how these four composers incorporated

\footnotetext{
${ }^{1}$ Corinne Kay Ong, "A Historical Overview and Analysis of the Use of Hungarian Folk Music in Zoltán Kodály's Háry János Suite, Dances of Marosszék, and Dances of Galánta."
} 
Hungarian elements in their music. For example, Bartók and Kodály's music based on Hungarian folk elements sounds more authentic than Liszt's music. Dohnányi also focused on originality mixed with virtuosity and romanticism; but he used less of the Lisztian Gypsy elements. All four composers contributed importantly to their nation, spreading the beauty of Hungarian music. 


\section{Chapter II:}

\section{Review of existing literature}

Most of the resources that I found relate to Bartók, Kodály and Liszt. There is plenty of information about these composers and how they incorporated folk elements in their works that I selected. The information that I found on Dohnányi is more biographical and less about folk influences in his writing. There is only scarce mention of his Variations on a Hungarian Folk Song.

Jonathan Bellman's book, The Style Hongrois in the Music of Western Europe, ${ }^{2}$ was helpful for my third chapter, "Hungarian folk music_-discussion and analysis," which introduces Gypsy music history and the characteristics of their music. Bellman's Chapter 4 is entitled "Stereotypes: The Gypsies in Literature and Popular Culture." His Chapter 8 discusses Liszt and briefly mentions the Hungarian Rhapsodies.

Dana Gooley's book, The Virtuoso Liszt, ${ }^{3}$ examines the world of discussions, journalism, and controversy that surrounded Liszt as a performer. The work is based on extensive research: journals and newspapers, as well as letters, memoirs, receipts, and other documents that shed light on Liszt's concertizing activities. The most relevant chapter to my topic is "The Cosmopolitan as Nationalist."

\footnotetext{
${ }^{2}$ Jonathan Bellman. The Style Hongrois in the Music of Western Europe. (Boston: Northeastern U Press, 1993).

${ }^{3}$ Dana Gooley. The Virtuoso Liszt. (Cambridge University Press, 2009).
} 
The main focus of Michaela Eremiášová's essay ${ }^{4}$ is the impact of Slovak and Hungarian folk music, and its modal heritage, upon Bartók’s Fourteen Bagatelles. Chapter 1 is on Béla Bartók’s life and work. I also found helpful information in Chapter 2: "Hungarian Folk Music and its Modal Heritage."

There is not much material about Dohnányi and his piano works. The books I found are primarily biographical, such as Ernst von Dohnányi: A Song of Life, by Ilona von Dohnány and James A. Grymes. ${ }^{5}$ This book is a biography of the artist, written by Dohnányi's widow Ilona. It gives a clear portrait of the composer, teacher, and piano virtuoso, seen through the eyes of one close to him. There is no analysis or specific information about his piano writing except mentioning the composition year (1917) of Variations on a Hungarian Folk Song, Op. 29.

The Bartók Companion by Malcolm Gillies ${ }^{6}$ brings together a selection of scholarly essays by several authors. After the introductory "Perspectives" chapters, the chief divisions of the volume are drawn according to musical genre: piano, chamber, stage, vocal, and orchestral. I found relevant material in these chapters: "Piano Music" and "Final Concertos."

Barbara Nissman's book ${ }^{7}$ is the first attempt to come to grips with Bartók’s entire piano output from the perspective of the music historian, biographer, or analyst. Pianist Barbara Nissman has made a close study of piano works focusing on the three piano concertos; she also looks at Bartók's other works based on folk music. This resource is very useful for my topic.

\footnotetext{
${ }^{4}$ Michaela Eremiášová, "Fourteen Bagatelles for Piano op. 6: no. I, III, IV, V, VI, VIII, and XI." PhD diss. (University of Rochester, New York 2011).

${ }^{5}$ Ilona Von Dohnányi and James A. Grymes. Ernst von Dohnányi: A Song of Life. (Bloomington: Indiana Univ. Press, 2002).

${ }^{6}$ Malcolm Gillies. The Bartók Companion. (Portland, Or.: Amadeus Press, 1994).

${ }^{7}$ Barbara Nissman. Bartók and the Piano: a Performer's View. (Lanham, MD: Scarecrow Press, 2002).
} 
Suchoff's book Béla Bartók: Life and Work ${ }^{8}$ is a comprehensive investigation of Béla Bartók as artist and as folklorist. It consists of two parts: the first is biographical and the second examines Bartók’s pioneering research in multinational musical folklore, including Hungarian folk music. The content gives detailed information on the Old and New Styles of Hungarian peasant music.

Béla Bartók: A Celebration, also by Benjamin Suchoff, ${ }^{9}$ is devoted to Bartók as a composer. Part I begins with program notes for selected masterpieces. Other essays examine folk-music sources in the composer's works, point to stylistic aspects in his early piano pieces, determine the sources of his unique musical language, and investigate his principles of composition. Part II includes publications of Bartók's collections of musical folklore: Hungarian, Romanian, Slovak, Turkish, and Yugoslavian. Part III includes chapters such as Bartók as Man of Letters," "The Bartók-Kodály Connection," and "Bartók in America"

The volume entitled The Selected Writings of Zoltán Kodály, ${ }^{10}$ by Zoltán Kodály, Lili Halapy, and Fred Macnicol, is made up of studies and articles written by Kodály. The writings have been grouped together within four sections. Section 1: pieces which concern folk music-Hungarian folk music naturally receives the greatest attention. Section 2: Essays showing another side of Kodály's musicological activities, in which he writes about predecessors and contemporary composers. This includes a special group of studies concerning his great companion in arms, Béla Bartók. Section 3 consists of the works in which he put his ideas about music education to paper, including ideas which formed the basis

\footnotetext{
${ }^{8}$ Benjamin Suchoff. Béla Bartók: Life and Work. (Lanham, MD: Scarecrow Press, 2001).

${ }^{9}$ Benjamin Suchoff. Béla Bartók: A Celebration. (Lanham, MD: Scarecrow Press, 2004).

${ }^{10}$ Kodály Zoltán, Lili Halápy, and Fred Macnicol. The Selected Writings of Zoltán Kodály. (Budapest: Corvina Press, 1974).
} 
of his fight for the reformation of music education in Hungary. Section 4 consists of several essays in which he speaks about himself and his own works.

The most relevant parts from Corinne Kay Ong's dissertation ${ }^{11}$ are in chapter 3, with such topics as: "Introduction to Hungary and Its Music," "Previous Scholarship on Hungarian Folk Music," "Classification of Folk Music," "Old Style Pentatonicism," "Parlando, Rubato Rhythm, Tempo Giusto," "Roma Traditions," and "Instrumental Music and Traditional Instruments." Chapter 4 gives an analysis of Dances of Marosszék .

James Grymes's Perspectives on Ernst von Dohnányi ${ }^{12}$ is another biographical book. Chapter 2 is the most relevant to my topic since it discusses elements of Dohnányi's piano music.

\footnotetext{
${ }^{11}$ Corinne Kay Ong, "A Historical Overview and Analysis of the Use of Hungarian Folk Music in Zoltán Kodály's Háry János Suite, Dances of Marosszék, and Dances of Galánta."

${ }^{12}$ James A. Grymes. Perspectives on Ernst von Dohnányi. (Lanham, Md.: Scarecrow Press, 2005).
} 


\section{Chapter III}

\section{Hungarian Folk Music: Discussion and Analysis}

I would like to start this chapter by looking at the origins of Hungarian music.

The Oriental aspect found in Hungarian folk music is fascinating and can be traced to different ethnic groups such as Genghis Khan's Mongols (who reached the Carpathians in 1241), the Turks who ruled Hungary from 1526-1686 (Ottoman domination), and the Gypsies (who might have come along with the Turks). Hungarian folk music is a great source of multiple cultural elements due to the constant interaction among different ethnic groups, along with economic, political, and religious changes. The oldest peasant songs are based on songs found in the "psalmody" and "lament" style (including children's songs and ritual pieces like funeral laments) which also exhibit the pentatonic mode. ${ }^{13}$

Hungary originates from the ancient Finno-Ugric nation and the Hungarian language derives from the Finno-Ugric family of languages. Judith Frigyesi suggests the possibility that these old-style songs come from Finno-Ugric musical elements that existed before the Hungarian

conquest. ${ }^{14}$ Here I am referring to a series of historical events ending with the settlement of the

\footnotetext{
13 Eremiášová, 5.

14 Judith Frigyesi, The Garland Encyclopedia of World Music, Europe, "Hungary: History of Folk Music," 736-739.
} 
Hungarian people in Central Europe at the turn of the $9^{\text {th }}$ and $10^{\text {th }}$ centuries.

During the period between the 11th-15th centuries when Hungary was a kingdom, the music was influenced by Gregorian chants and European melodic styles. Based on the influences of other cultures we can assume that music involved Finno-Ugric, Turkish, and medieval European folk and chant elements. Unfortunately there is no surviving evidence of the repertoire sung during this time.

The Gypsy community had a special impact on secular Hungarian music. Some of them were kept as slaves by Ottoman and Eastern European aristocrats. Gypsies were known for a varied mixture of "exotic sounding" melodies from different regions. This mixture includes Turkish musical material and may explain the occurrence of the Turkish modes in 17th-century Hungarian folk songs. ${ }^{16}$

In discussing folk elements one has to establish what the differences are between folk music and art music. First there are differences of purpose, function and social role. Tunes that survived for a long time in many places may be denoted as folk music; tunes are born in a community, spread within the community, and appeal to the community. On the other hand, art music derives from an individual and has been invented by a composer. Folk music is not attached to any individual personality, it may exhibit a multitude of variations in time and space, and it is preserved by oral tradition, rather than by writing it down. ${ }^{17}$

Among the melodies employed by Liszt in his Hungarian Rhapsodies, and by Brahms in

\footnotetext{
15 Eremiášová, 6.

16 Ibid., 7.

17 Zsolt Strajber. "Hungarian Peasant and Folk Music". Retrieved April 12, 2017, from http://www.indiana.edu/ iuihsl/1 thesis7.htm.
} 
his Hungarian Dances, there are four or five peasant melodies, and even these appear in a much distorted "Gypsy-like" form. Many Gypsy musicians place their art at the disposal of anyone who engages them to play. By contrast most peasants do not perform for city folk; they sing only after gaining trust. Liszt, unfamiliar with the Hungarian language, was unable to realize this, and considered the Hungarian-style music to be the same as the music played by Gypsies. ${ }^{18}$

The two leading personalities of Hungarian musical folklore studies, Bartók and Kodály, were well aware of that need. In order to analyze the predominant styles of Hungarian folk music, first they had to compare the characteristic Hungarian types with the foreign ones. It was Bartók who first divided the Hungarian-language territory into areas of typical musical dialects in his book, Hungarian Peasant Music, published in $1924 .^{19}$

The first person who collected Hungarian peasant music systematically was Béla Vikár, who gathered some 7000 melodies around 1890 . He toured the country using a phonograph to record the tunes as well the texts of traditional pieces. In 1905 the material he recorded from County Somogyi was published in Magyar Népköltési Gyüjtemény (Hungarian Folk-Art Collection). This collection includes melodies in the ancient Hungarian peasant-music style. Vikár was primarily interested in the texts rather than the music. His inability to read music led him to decide to use Edison's invention, for he realized that the precise analysis of the melodies was as important as the analysis of the songs. In 1903 Kodály became familiar with Vikár's collection. ${ }^{20}$

Without systematization, it is quite impossible to understand the nature of folk songs.

\footnotetext{
${ }^{18}$ Bellman, 11-17.

${ }^{19}$ Járdányi, 287-291.

${ }^{20}$ Sebő Ferenc: Vikár Béla Népzenei Gyüjtései, accessed April 12, 2017, http://folkradio.hu/folkszemle/sebo_vikar/index.php. Translated by Helga Scheibert.
} 
Folk music is analogous to a society in which the types and not the individuals give it its character. The folk creation is nothing else but the formation of variants. The only way of determining variants, types and styles is by systematization. ${ }^{21}$

Hungarian vocal songs are characteristically established on a strophic structure and either of two rhythmic styles: parlando-rubato and giusto. Theoretically, parlando-rubato refers to the natural rhythm of the spoken text. Giusto style is based on a metrical framework but there is certainly rhythmic flexibility. Parlando-rubato appears mainly in solo performance, while giusto is typical for choral performance. ${ }^{22}$

It is crucial to note that Hungarian songs are usually syllabic; however, ornamentation is very important. Ornaments were much longer and structurally more substantial before the twentieth century, according to older recordings. ${ }^{23}$

The various melodic types of Hungarian folk music include several characteristics such as the use of the pentatonic scale, and related types such as major-mode, descending, octave-range types, psalmody and lament styles. All these styles were divided by Bartók and Kodály into Old, New and Mixed Styles. ${ }^{24}$

\section{The Old Style of Hungarian Peasant Music}

Bartók was fascinated by these Old Style Hungarian melodies:

These Old Style tunes are to be considered as purely Hungarian creations; so far as we know, nothing similar in style and character is to be found in any other country. The parlando-rubato eight-syllable tunes exercised a strong influence upon the peasant music of the Romanian districts adjoining the region of the

\footnotetext{
${ }^{21}$ Pál Járdányi, "Experiences and Results in Systematizing Hungarian Folk-Songs," Studia Musicologica Academiae Scientiarum Hungaricae 7, no. 1/4 (1965): 287-291, doi:10.2307/901435.

22 Ibid.

${ }^{23}$ Eremiášová, 8.

${ }^{24}$ Béla Bartók, Hungarian Folk Music, transl. by M. D. Calvocoressi (London: Oxford University Press, 1931$), 11$.
} 
Székely people. ${ }^{25}$

The structures of these melodies are non-architectonic (in other words, non-rounded), like $\mathrm{ABCD}$ or $\mathrm{ABAB}$. Their isometry consists usually of four lines with the same number of syllables in each. ${ }^{26}$

When the songs have twelve, eight, or six syllables, the rhythm is parlando rubato. This is most often found in the old Hungarian style. Tempo giusto is used when the songs contain seven, nine, ten, or eleven, syllables. ${ }^{27}$

There are traces of pentatonicism (see Figure 1) in the folklore of Transdanubia as well as among the Hungarian population of the Northern Carpathian Mountains.

$$
\text { (see Figure 1). }{ }^{28}
$$

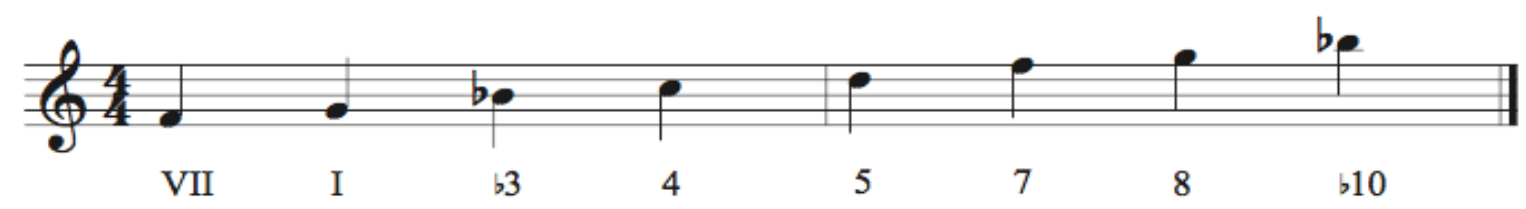

Figure 1. Pentatonic scale

\footnotetext{
${ }^{25}$ Nissman, 35 .

${ }^{26}$ Yu-Young Lee, "Béla Bartók's Eight Hungarian Folk Songs for Voice and Piano: Vocal Style as Elaborated by Harmonic, Melodic, and Text Factors." PhD diss. (University of Texas, Austin 2006), 4.

${ }^{27}$ Yu-Young Lee, 6.

${ }^{28}$ Kodály, Halápy, and Macnicol, 11.
} 

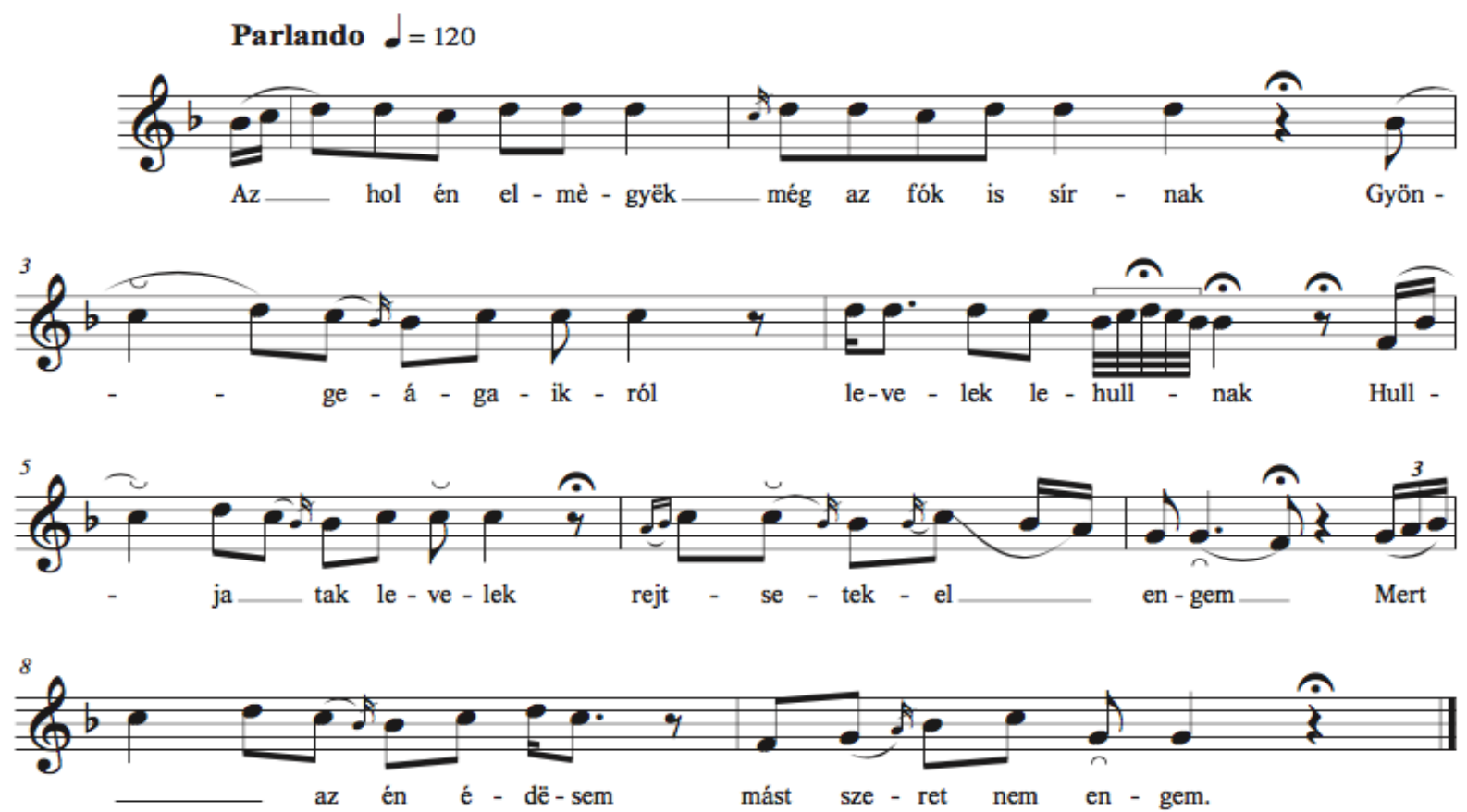

Figure 2. Z. Kodály, Székely tune from Marostorda County ${ }^{29}$

For the particular effect that distinguishes these songs from other kinds of music, no doubt their rhythm, ornamentation, and structural peculiarities play an important role, but the so-called "Magyarscale" is the most characteristic feature of Hungarian music. The five-tone scale on G is: $\mathrm{G}-\mathrm{B}-$ flat $-\mathrm{C}-\mathrm{D}-\mathrm{F}$, with the second and sixth degrees missing. It is certain that the five-tone melodic structure of Hungarian music offers keys to many unopened doors. Many favorite nuances of the folk music have their roots in the pentatonic idiom. The dominance of pentatonic scales in Hungarian peasant music was first recognized by Kodály. He pointed out that pentatonicism is the fundamental layer of the Hungarian melopoeia. The rhythmic aspect comes from dance and language.

\footnotetext{
${ }^{29}$ Lajos Bárdos. 101 Magyar Népdal. (Budapest: Magyar Cserkészszövetség, 1942), 55.

${ }^{30}$ Corinne Kay Ong. "A Historical Overview and Analysis of the Use of Hungarian Folk Music in Zoltán Kodály's Háry János Suite, Dances of Marosszék, and Dances of Galánta."
} 
Béla Bartók first discovered a large number of pentatonic melodies in the Székely region of Transylvania in 1913. According to him, there are three basic forms of the pentatonic scale in Old Style Hungarian songs:
A. The pure pentatonic scale

B. The pentatonic scale, in which the scale degrees 2 and 6 appear as ornamental

C. The pentatonic scale, in which the scale degrees 2 and 6 appear as real notes. They usually appear on a weak beat, never at the end of a melody. These additional scale degrees transform the pentatonic scale to Dorian, Aeolian, or Phrygian modes. ${ }^{31}$

The following quote is Bartók's discussion about the pentatonic system:

The isometric twelve- and eight-syllable tunes in the pentatonic system are characteristic of the Old Style. They are the oldest known materials of Hungarian peasant music, not to be found among any other races except as obvious imports. Proofs of antiquity are: the pentatonic system, the more primitive structure, rounded off but not constituting architectonic form, isometry of tune-lines, and similarity to Rumanian peasant music. ${ }^{32}$

Pentatonic scales can also be found in Liszt's music; the major-pentatonic scale is his

favorite. We find examples of such pentatonic scales in Dante Sonata and in "Invocation" (one of the Harmonies Poetiques); here Liszt uses a descending pentatonic scale to emphasize harmonic transitions. In the concert etude "Un Sospiro" the melody in the opening measures is also pentatonic.

The art music of Europe, from the beginning of the sixteenth until the nineteenth century, is infused with embellishment and ornamentation, which had become a specialized and complex

\footnotetext{
31 Yu-Young Lee, “Béla Bartók's Eight Hungarian Folk Songs for Voice and Piano: Vocal Style as Elaborated by Harmonic, Melodic, and Text Factors.” PhD diss. (University of Texas Austin 2006), 13.

${ }^{32}$ Lee, 14.
} 
art, relative to performance practices. The ancient Magyar (Hungarian) manner of ornamentation is a remnant of this style, being related to a similar Eastern practice. Its antiquity deserves our attention particularly since we probably won't hear it much longer in musical compositions. ${ }^{33}$

The quickest way to discover the source of the melodic construction is through studying the end of each phrase. The phrase endings function as guide posts depicting the basic outline of the melody. The most common line endings in pentatonic melodies are: ${ }^{34}$

\begin{tabular}{|c|c|c|c|c|}
\hline \multicolumn{2}{|c|}{ Endings } & mostly & rarely & never \\
\hline & I & $5,7,4$ & VII, 1 , flat 3,8 & flat 10 \\
\hline \multirow[t]{2}{*}{ Lines } & II & flat 3 & $\mathrm{VII}, 1,5,4,7$ & 8 , flat 10 \\
\hline & III & flat 3, VII, 1 & 4,7 & 5,8 , flat 10 \\
\hline
\end{tabular}

2. The New Style of Hungarian Peasant Music

This particular style appeared in the nineteenth century because of the increased travel by peasants into the city. These songs absorbed more popular elements and created a new, but still homogeneous, Hungarian folk style. ${ }^{35}$

These songs have the same four-line stanza structure and in many cases the same pentatonic turns as the Old Style melodies, but there is a marked difference in content structure.

\footnotetext{
${ }^{33}$ Lee, 9.

${ }^{34}$ Lee, $11-13$.

${ }^{35}$ Suchoff, Béla Bartók: Life and Work, 166.
} 
The New Style is architectonic: AABA and ABBA instead of free sectional arrangements such as $\mathrm{ABCD}$ and $\mathrm{ABBC}$. The ABBA structure is uniquely Hungarian, usually with dominants as caesuras, the rhythm is for the most part tempo giusto, and there are hardly any ornamental tones, as shown in Figure 3.
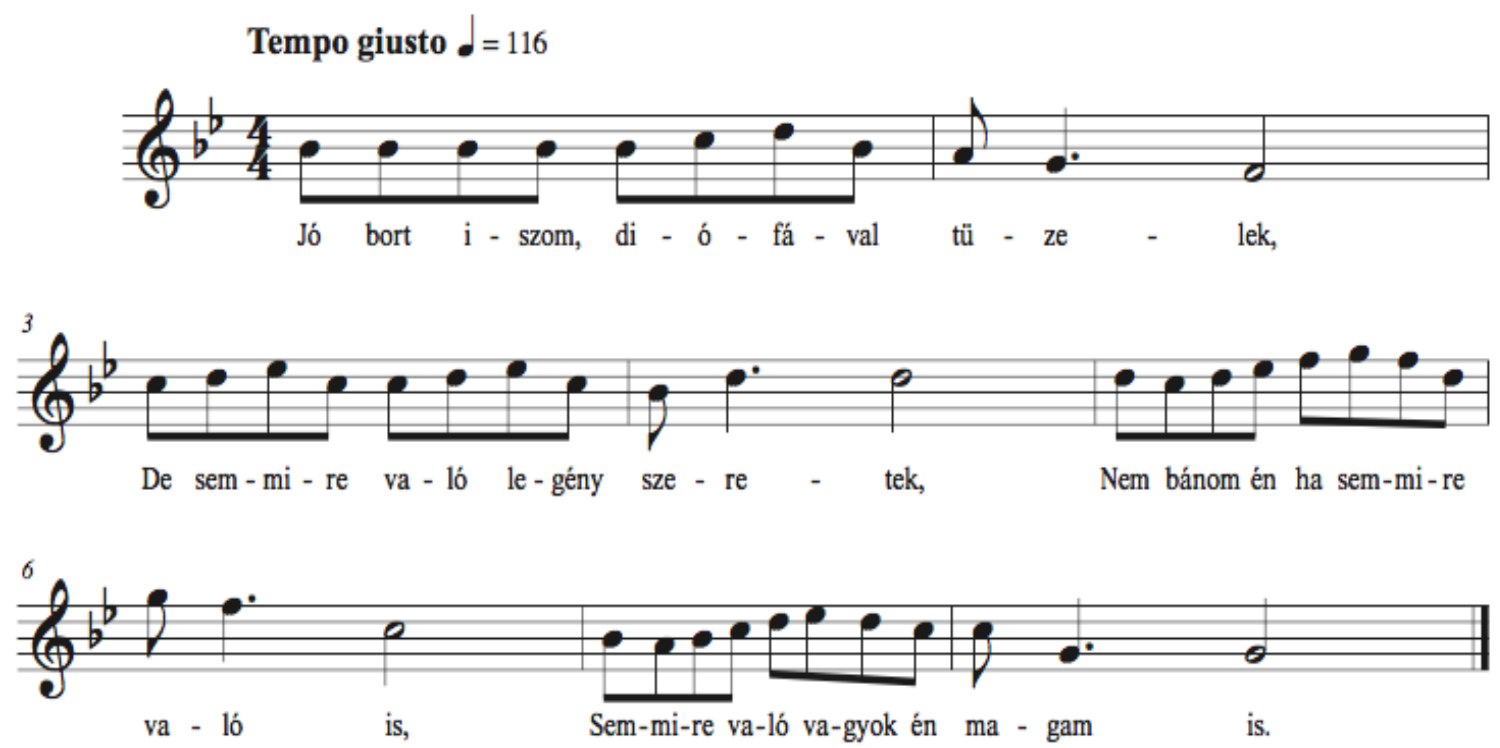

Figure 3. L. Lajtha, Folk Song from Transylvania ${ }^{36}$

Both New and Old Style folk songs have common time in the melodies, with rubato; but some melodies move quickly in a dance-like rhythm (tempo giusto), as illustrated above.

The variable tempo giusto has free rhythm in which pairs of quarter-notes adjust themselves to the length of the accompanying text syllables. Concerning the rhythm, it is mostly isometric, the lines are equal length $(6,7,8,11$ or 12 syllables $)$; dance tunes most frequently consist of 11-syllable lines.

Out of the rhythm of the seven-, eight-, and eleven-syllable tunes in adjustable tempo giusto

${ }^{36}$ Ibid, 166. 
rhythm has evolved the rhythm of most of the tunes representing the new Hungarian musical style.

\section{Other Tunes in Hungarian Peasant Music}

This is a class of Mixed Styles, showing Western European influences such as German, Czech and Slovak. Many of the same melodies are found both in Hungarian and Slovak peasant music. $^{38}$

\section{Hungarian instruments.}

Typical Hungarian instruments include the violin, several types of shepherd pipes, Jew's harp, clarinet, and a two-stringed guitar. The most characteristically Hungarian of all, though, is the cimbalom, a large hammer dulcimer; its special sound is frequently invoked by Liszt, especially in his Hungarian Rhapsodies.

The Hungarian violin is identical to the European violin, including the tuning. Hungarian fiddle playing is known for its passion, romance, and virtuosity. Surely Hungarian fiddle music is Gypsy music. Yet we could find considerable resentment towards this stereotype, and while there is much appreciation of the skill of Gypsy fiddlers, it is considered to be Hungarian music, not Gypsy music, and the widespread revival in folk music since the seventies has been largely non-gypsy in origin. When two violinists form a "band" to play, the second violin has a flat bridge and three strings tuned to G, D and A. This arrangement allows the three strings to be bowed together, in order to play an accompaniment of

trichords. $^{39}$

\footnotetext{
${ }^{37}$ Suchoff, Béla Bartók: Life and Work, 166.

${ }^{38}$ Ibid, 167.

${ }^{39}$ Suchoff, Béla Bartók: Life and Work, 174.
} 
Shepherding had a great role in the life of the peasantry. This implied typical shepherd instruments such as the furulya (peasant flute), about 12-15 inches long, mostly with six holes, the end-blown type. There is also the long peasant flute, about 25-30 inches with five finger-holes, and the double peasant flute which consists of two flute-like pipes of equal length.

40

The doromb (jew's-harp) is a favorite instrument of peasant women. It seems that this instrument was restricted to women's or children's leisure-time activities. ${ }^{41}$

The duda (bagpipe), also called kanásztülok (swineherd's horn) or fakürt (wooden horn) is mostly used in Transylvania. From among the other wind instruments, the peasants used the high-tuned klarinet as a solo instrument at the beginning of the century. The citera (zither) was also popular (around the mid-19 $9^{\text {th }}$ century). ${ }^{42}$

The most important instrument, to which we find many references in the music of Franz Liszt and other composers is the cimbalom, which is the Hungarian dulcimer. In addition to many traditional uses, it was heard for the first time in a formal European concert setting when Kodály's Hary János suite was performed, with an important solo plus some obbligato parts. The instrument is a direct descendant of the santur of the Middle East. The santur has 80 strings, in courses of four; the soundboard has groups of small holes in the form of a circle. What makes it different from a dulcimer is that the tuning pins are placed into the side of the instrument.

Like all primitive dulcimers, the santur is not chromatic and the player has to tune to the mode

\footnotetext{
${ }^{40}$ Ibid, 174.

${ }^{41}$ Ibid, 175.

${ }^{42}$ Www.nepzene2.eoldal.hu, "A magyarság Népi Hangszerei, Népzene" accessed April 03, 2017, http://www.nepzene2.eoldal.hu/cikkek/hangszerek/a-magyarsag-nepi-hangszerei.html. Translated by Helga Scheibert.
} 
required, by moving the center row of bridges. ${ }^{43}$

The cimbalom is similar to the santur except that it has a chromatic range of four octaves, and stands on four legs. It is still used by Hungarian peasant musicians as a solo instrument; nowadays it is also heard in restaurants and at weddings, either as a solo instrument or in a group usually consisting of violin, cimbalom and double bass, typically played by Gypsies or peasant musicians. $^{44}$

\section{Gypsy music-history and characteristics of the music.}

Gypsies and their music have a fascinating and intertwined history.

The Roma people (Gypsies, Tzigane, Zigeuner...) originated in North Central India and, starting around $300 \mathrm{BC}$, started travelling, first to North Western India, then to Persia and then, sometime in the middle ages, to Europe. They were thought at the time to have come from Egypt, hence the name gypsies. They have always remained on the margins of society, avoiding farming, but making a living in such trades as metalworking, horse-dealing and entertaining. Within the gypsy community, musicians have the highest status. There are different tribes of gypsies; the ones that arrived in Hungary in the 15th C, and who eventually made up the bulk of the professional "restaurant" musicians are the Romungro gypsies. A second group, the Vlach or Olah gypsies arrived from the Romanian region of Wallachia much later, in the 19th C. Until the last few decades this group, more rural in character, had no interest in professional music, and the music they played for themselves was almost entirely vocal and percussive in nature.

What is Gypsy music? We hardly know if such a thing exists, for the musical life of

Gypsies has so far been little investigated in a scientific way.

The Austrian National Encyclopedia points out:

The Gypsies are full of natural capabilities, a jack-of-all-trades, who tries everything, possesses talents and gifts for everything... Now they are the most

\footnotetext{
${ }^{43}$ John Leach, (1972). The Cimbalom. Music and Letters, LIII(2), 134-142. doi:10.1093/ml/liii.2.134.

${ }^{44}$ Leach, 134.

45 "Hungarian and Gypsy Fiddle," Hungarian and Gypsy Fiddle, 1, accessed April 02, 2017, http://www.fiddlingaround.co.uk/hungarian.
} 
excellent musicians in Hungary, and unsurpassable in Hungarian performance. They are masters not only in the making and handling of instruments, but also even imaginative composers and poets, even if they never write down a note, or ever even know a note.

The pieces that are usually called Gypsy music — that is, tunes played by Gypsy bands - are mostly compositions by dilettante members of the Hungarian middle class, town dwellers, or landed gentry. These popular art songs or, as Bartók calls them, "urban folk songs," were transformed by Gypsy bands in Vienna, Budapest, and Hungarian towns. ${ }^{47}$

Sometimes a rural folk song, favored by the public, was also added to the Gypsy repertory. However the Gypsies played only those urban or rural songs that were in current fashion. $^{48}$

They rarely invented new material, instead preferring to improvise on or embellish the melodies that the public favored. In 1850 the fame of Gypsy performance style became widespread and this music was mistakenly identified as the Hungarian folk song. ${ }^{49}$ The source of music on which Schubert, Liszt, Brahms, and other composers would draw was not purely Hungarian, but a combination of Hungarian popular dances and songs which were interpreted by Gypsies, who were the most prominent musicians in Hungary. This "exotic" sounding Hungarian style became popular, as composers imitated and idealized the music they heard, interpreting it as Hungarian national style. ${ }^{50}$ Nissman cites a statement by Bartók:

At most one could add that this music is played "a la tzigane," which seems to be the only original element contributed by the Gypsy nation to Hungarian art music composed in the popular fashion. It is absolutely obvious that the melodies

\footnotetext{
${ }^{46}$ Bellman, 88 .

47 Ibid, 11.

${ }^{48}$ Suchoff, Béla Bartók: A Celebration, 181.

${ }^{49}$ Ibid, 181.

${ }^{50}$ Bellman, 11-12.
} 
featured in Liszt's Hungarian Rhapsodies are not gypsy products but melodies of popular amateurs; in most cases, we are acquainted with the name of these composers - educated dilettantes.

In general, the Gypsies borrow from the music of whatever people they happen to be living among: Bulgarian Gypsies play a different music from their cousins in Russia, and the repertory of Albanian Gypsies does not correspond to that of the Gypsies of Slovakia. In Romania, as elsewhere, the Gypsies have for centuries played whatever their customers wanted to hear. Liszt became an innocent victim of this loose terminology.

Hungarian-born, but not knowing the language, Liszt was convinced that Gypsy music was the authentic Hungarian folk music. In fact Bartók also thought so while he lived in Budapest in 1899, particularly because of the formal style of Liszt's Hungarian Rhapsodies. ${ }^{52}$

However the urban Gypsy bands played nothing but popular art music of recent origin, primarily to entertain an audience with low-order needs. Gypsy musicians had little interest in self-documentation or academic debate; they preferred simply to play whatever music people want to hear. The music was performed in two general styles, slow and fast. The slow type is called hallgato, which in Hungarian means "to be listened to"; it is free, improvisatory and rhapsodic. The fast type, called cifra (meaning "flashy"), is intended for dancing and became known as verbunkos. ${ }^{53}$ The name is derived from the German word werbung, a noun derived from the verb werben that means, in particular, "to recruit." This music and dance appeared during military recruiting, which was a frequent event at these times when the Habsburg Emperors were frequently at war. Therefore the character of the music derives from the military

\footnotetext{
${ }^{51}$ Nissman, 84-85.

${ }^{52}$ Suchoff, Béla Bartók: A Celebration, 184.

${ }^{53}$ Bellman, 17.
} 
march tempo. Some other characteristics of verbunkos include duple meter, gradual increase in tempo from very slow to very fast, and rich ornamentation. Dancing as ritual, as a form of expression, and as a crucial aspect of living seems always to be an extremely strong element in Magyar culture. These dances reflected the personality of Hungarians: serious, courageous and free spirited. The later form of the verbunkos is the csardas. It has two primary sections: lassu (slow) and friska (fast). The slow section is in heavy $4 / 4$ meter, while the fast section can be either one or several different dancing songs. It has a specific step (knocking the heels together) which is found in some Oriental dance. ${ }^{54}$

Phrases were often rounded off with a melodic cadential figure called bakázo. This figure generally begins on the second scale degree, descends to the tonic, and slides down to the leading tone on the penultimate note.

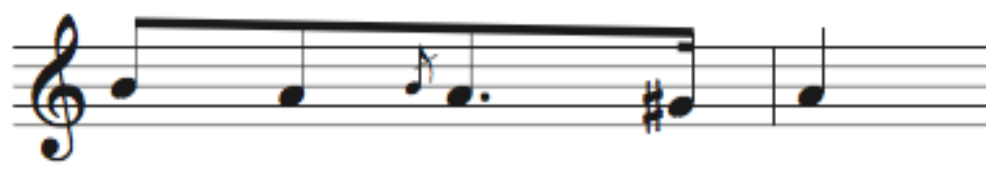

Figure 4. bakázó $^{56}$

Liszt says, “ nobody can play or dance the Csárdás like the Gypsies themselves.” All the Gypsy dances of Europe strongly resemble Oriental dances. ${ }^{57}$

\footnotetext{
${ }^{54} \mathrm{Ibid}, 21$.

55 "ProQuest Subject Index - Music at JAMES_MADISON_UNIVERSITY," 6, accessed April 1, 2017, http://www.bing.com/cr?IG=CE088B31632D42ABA4085E7D94339998\&CID=0307D522BAA862620A27DF75 BB996386\&rd=1\&h=rCGW6bX8nOujUwPunzD6RtG5z-tYuWn05o-R4slFUmg\&v=1\&r=http\%3a\%2f\%2fgrauest .com

56 "ProQuest Subject Index - Music at JAMES_MADISON_UNIVERSITY," 6, accessed April 1, 2017, http://www.bing.com/cr?IG=CE088B31632D42ABA4085E7D94339998\&CID=0307D522BAA862620A 27DF75BB996386\&rd=1\&h=rCGW6bX8nOujUwPunzD6RtG5z-tYuWn05o-R4slFUmg\&v=1\&r=http\%3 a\%2f\%2fgrauest.com

${ }^{57}$ Full text of "Gypsy and Oriental Music," accessed April 25, 2017, http://archive.org/stream/jstor-534723/534723_djvu.txt.
} 
The two leading instruments of Hungarian Gypsy orchestras are the violin and cimbalom. Usually the violin plays the melody, but it is often played by the cimbalom. All the other instruments, second violin, viola, cello and contrabass, simply support these instruments. There are several fiddle techniques specifically associated with Hungarian Gypsy playing: small jangling ornaments, grace notes, extreme ranges and pizzicato. ${ }^{58}$

As we saw, Hungarian peasant songs are categorized in three groups. Suchoff, in his book, Béla Bartók: A Celebration, also divided Gypsy songs into three major categories: Old, New and Mixed Styles.

The first category is the Old Style song in which the melodic structure enclosing each text line usually has a different contour but similar rhythm in each line, which provides unity. $^{59}$
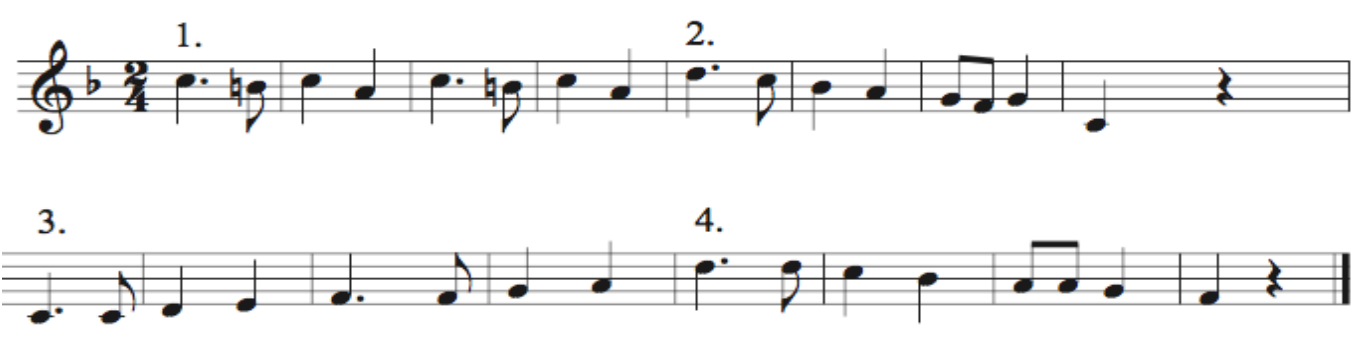

\section{Figure 5. Ég a Kunyhó ("The Hut is Burning") ${ }^{60}$}

The second category is the New Style song, which became popular among the young people in rural areas. The characteristic structure here is ABBA, where B sections have a higher

\footnotetext{
${ }^{58}$ Bellman, 97.

${ }^{59}$ Suchoff. Béla Bartók: A Celebration, 182.

${ }^{60}$ Suchoff. Béla Bartók: A Celebration, 182.
} 
melodic contour. Each text line has the same number of syllables. ${ }^{61}$
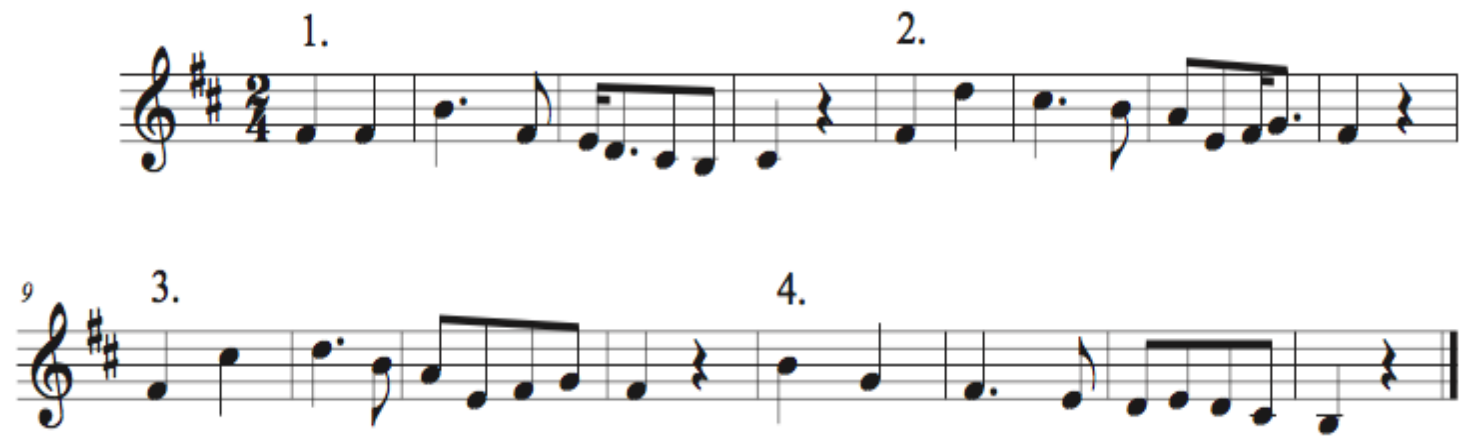

Figure 6. Csak Egy Szép Kislány Van a Világon ("There is Only One Pretty Girl”)" ${ }^{62}$

The third category represents songs with features of different national provenance, such as Hungarian and Slovak. For example the Mixed Style Hungarian folk song migrated between Hungarian and Slovak territories. As we see in the example below, some of the characteristics are melodic and rhythmic repetition. These songs had a great success and were not only played by Gypsy bands but also by members of the educated classes, including Johannes Brahms. He heard the following melody played by a Gypsy band in a Vienna cafe and made it part of his Hungarian Dance No. $10 .^{63}$
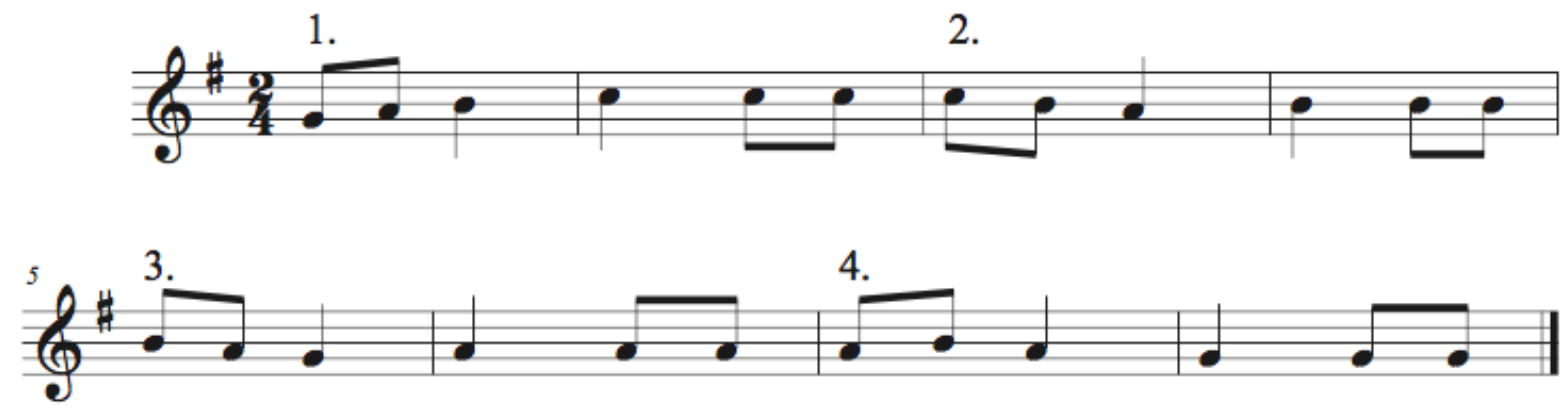

\footnotetext{
${ }^{61}$ Ibid, 182.

${ }^{62}$ Ibid, 182.

${ }^{63}$ Suchoff. Béla Bartók: A Celebration, 182-183.
} 


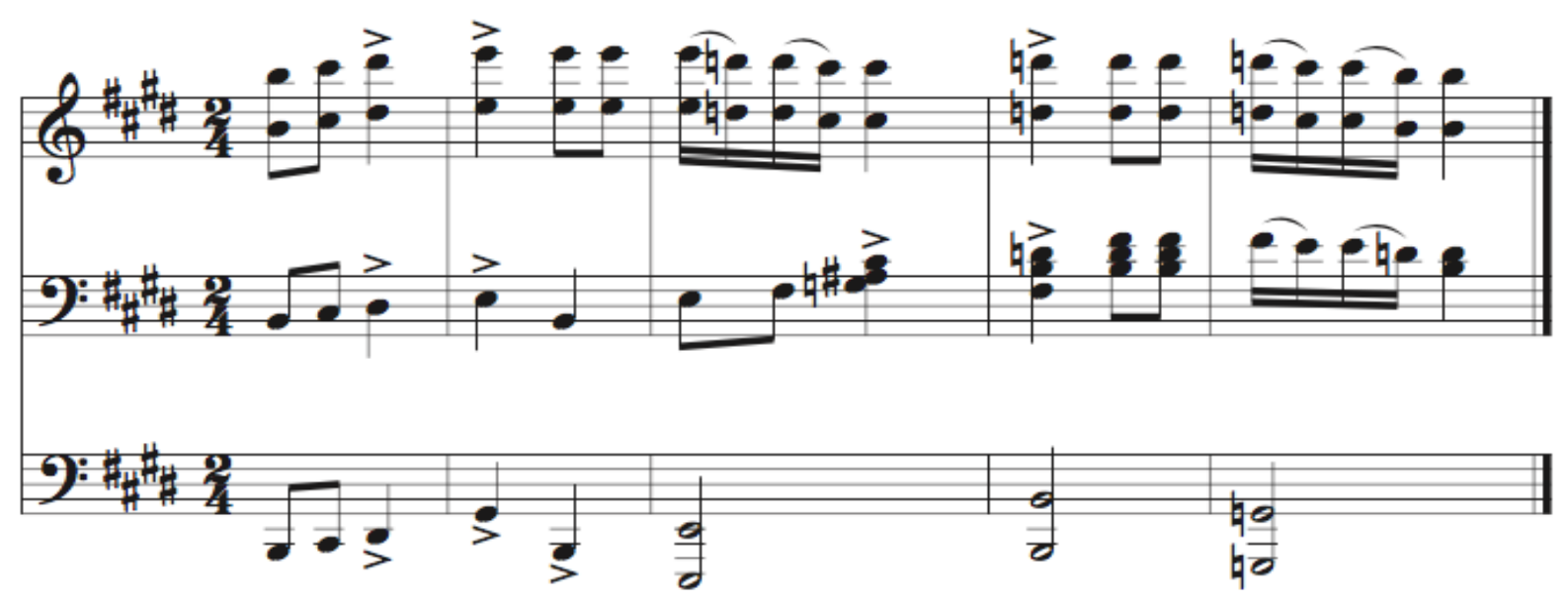

Figure 8. Brahms, Hungarian Dances for Orchestra, No. $10^{65}$

Gypsies employ double harmonic minor scales in their music, for example: C, D, E flat, F sharp, G, A flat, B, C. The raised fourth gives importance to the fifth degree by acting as a secondary leading tone. Frequently they also use the diminished seventh and the dominant with an augmented fifth. Arabic music has the same peculiarities. ${ }^{66}$

According to Liszt, some of the most striking effects in the Gypsy style are caused by the harmony. ${ }^{67}$ Here is how Liszt describes it:

He made it dance and glitter in the fascination of a wild harmony, fantastic and full of discords; and thus, by a mixture of unexpected outline, glaring color, sudden change and quick transformation, endowed it with many seductive features.

\footnotetext{
${ }^{64}$ Ibid, 183.

${ }^{65}$ Ibid, 183.

${ }^{66}$ Bellman, 120-121.

${ }^{67}$ Ibid, 122.

${ }^{68}$ Ibid, 124.
} 


\section{Chapter IV}

\section{Liszt}

\section{About the composer.}

Franz Liszt was born on October 22, 1811, in Raiding, Hungary. His father, Adam, was an official in the service of Prince Nicholas Eszterházy, whose palace in Eisenstadt was frequented by many celebrated musicians. Adam was a talented amateur musician who played the cello in the court concerts. By the time Franz was five years old he was attracted to the piano and was soon given lessons by his father. ${ }^{69}$ He began to show interest in both church and Gypsy music. Liszt developed into a religious child also because of the influence of his father, who during his youth had spent two years in the Franciscan order. ${ }^{70}$ Franz began to compose at the age of eight. He was only nine years old when he made his first public appearance as a concert pianist in Bratislava. His playing impressed the local Hungarian magnates; they put up the money to pay for his musical education for the next six years. Adam obtained a leave of absence from his post and took Franz to Vienna, where he had piano lessons with the composer Carl Czerny, who had been a pupil of Ludwig van Beethoven; Liszt also studied composition with Antonio Salieri, the music director at the Viennese court. The legend that Beethoven attended one of Liszt's concerts and kissed the prodigy on the forehead might be apocryphal, but Liszt certainly met Beethoven.

\footnotetext{
${ }^{69}$ Raphaël Ledos de Beaufort. Franz Liszt: The Story of His Life. (Boston: O. Ditson \& Co., 1887), 9-16.

${ }^{70}$ Beaufort, 17-20.
} 
In 1823 he moved to Paris and was refused admission to the Paris Conservatoire because he was a foreigner. Instead he studied with Anton Reicha, a pupil of Haydn. His Paris debut on March 7, 1824, was sensational. ${ }^{72}$

Between 1835-1840 he toured England, Italy, France and Switzerland as a virtuoso pianist. In 1840 he settled in Weimar, where he became popular as a conductor. Students from all around the world came to meet him and study composition and piano. ${ }^{73}$

Liszt spent his final years between Weimar, Rome, and Budapest, where he became director of the Hungarian Music Academy, later named the Liszt Academy. He died of pneumonia in 1886 , at Bayreuth. ${ }^{74}$

As a composer he radically extended the technique of piano writing, giving the instrument not only brilliance, but also a full, rich, almost orchestral sound. Most of his works bear titles and are representations of nature, poetic ideas, or a work of literature or art. His late compositions with chromatic harmonies helped lead eventually to the breakdown of tonality and ultimately to the atonal music of the $20^{\text {th }}$ century. Liszt also greatly contributed to the symphonic poem for orchestra and the method of "transformation of themes," by which one or two themes in different forms can provide the basis for an entire work, a principle from which Wagner derived the leitmotifs in his operas. As a pianist, Liszt was the first to give complete solo recitals. He encouraged the performance of music by Bach, Beethoven, Schubert, Berlioz, Wagner, and

\footnotetext{
${ }^{71}$ Ibid, 33-43.

${ }^{72}$ Ibid, 79.

${ }^{73}$ Ibid, 102-119.

${ }^{74}$ Beaufort, $167-200$.
} 
Schumann, by transcribing their works for solo piano and playing them in concerts at a time when they were insufficiently appreciated. ${ }^{75}$

\section{The Hungarian Rhapsodies, Highlighting the 15th Rhapsody.}

Liszt was a nine-year-old boy when he left Hungary, returning for a visit in 1840 after two decades of being away. Living in Vienna and Paris, he still felt a special connection to Hungary:

I am Hungarian and know no greater pleasure than to present honorably the first fruits of my development and education as an initial offering of the most sincere affection and gratitude before leaving to France and England; steady hard work and travels may bring what is still lacking in my playing to greater perfection, and perhaps place me in the fortunate position to have become a branch to adorn my beloved country.

Starting with his visit to Pest in 1840, Liszt began devoting himself more and more to raising funds for national and cultural institutions: the Hungarian National Theater, the future conservatory of Pest which later was named the Liszt Academy. ${ }^{77}$

In 1848 the Magyars had become restless and ambitious, and the national pride of Hungary was awakened. Liszt was still in Vienna when he heard the details of Hungary's political struggles, which provoked a burning desire in him to see the land of his birth again. He had played some Hungarian music in his concerts at Vienna, but these were Schubert's compositions. However, the public, in deep ignorance of many of Schubert's treasures, believed them to be Liszt's own. Before he composed the Hungarian Rhapsodies, he occasionally improvised on various Hungarian themes. It is known that he improvised on the Rákóczi March

\footnotetext{
${ }^{75}$ Ibid, 47-73.

${ }^{76}$ Gooley, 120.

${ }^{77}$ Beaufort, 109-111.
} 
in Budapest. ${ }^{78}$

Such proofs of his Hungarian blood were convincing. His Hungarian Rhapsodies not only rank among his most powerful and convincing works, but also count as superior specimens of national music in general. Liszt started a new era of Hungarian music with his rhapsodies. ${ }^{79}$ Who before Franz Liszt would have dreamed of using cimbalom effects in legitimate piano playing? Liszt found amazing ways of imitating the cimbalom to perfection. ${ }^{80}$

Liszt writes about the cimbalom:

The zymbala supplies the rhythm, indicates the acceleration or slackening of time, and also the degree of movement...Shares with the first violin the right to develop certain passages and to prolong certain variations indefinitely according to the good pleasure of the moment. He is necessarily one of those who conduct the musical poem.

Liszt's piano music provides creative examples of stylized cimbalom effects. These imitations on the piano involve frequent use of the sustaining pedal and occasional blending of harmonies. (See figures 10 and 15.)

Liszt realized that the peculiarities of Gypsy music rendered it unmanageable for symphonic treatment. Haydn, Beethoven and Schubert did not intend to write real Hungarian music; they only endeavored to introduce some of its spirit in the writings and they treated the Gypsy themes very much like themes of their own invention. Liszt, however, had a different task; he was bound to make Hungarian music an independent and acknowledged factor in modern music. He turned to Gypsy music to rescue it for art by giving it a characteristic form to dwell in,

\footnotetext{
${ }^{78}$ Lynn Hooker M. Redefining Hungarian Music from Liszt to Bartók. (New York: Oxford University Press, 2014), 81.

${ }^{79}$ James Huneker. Franz Liszt. (Place of publication not identified: The Classics Us, 2013), 160.

${ }^{80}$ Huneker, 161.

${ }^{81}$ Bellman, 108.
} 
a form that was all its own and with nothing but the ingredients of its best features. It was this form that Liszt chose to call "rhapsody." ${ }^{82}$ On the other hand, Bartók realized that the true origin of these rhapsodies was far more Gypsy than Hungarian and his viewpoint is rather harsh:

The compositions that ought to be closest to us, his Hungarian Rhapsodies, are less successful works (perhaps it is for this reason that they are so widespread and held in such high esteem). Despite a great many marks of genius, these Rhapsodies are mostly stereotypes; they represent Gipsy music_-sometimes even blended with Italian music (the Sixth) ${ }_{83}$ and as regards form, they are sometimes veritable conglomerates (the Twelfth).

Much Gypsy music is based on a specific scale, the harmonic minor scale with a raised fourth, sometimes called the "Gypsy scale" or "double-harmonic scale." This scale can be found on the last page of Liszt's 15th Rhapsody, where it runs: A, B flat, C sharp, D, E, F, G sharp, A. Other Rhapsodies have similar scales. Certain "modal scales” play an important part in Liszt's music. These alternate a tone, minor third or perfect fourth with the semitone. ${ }^{84}$

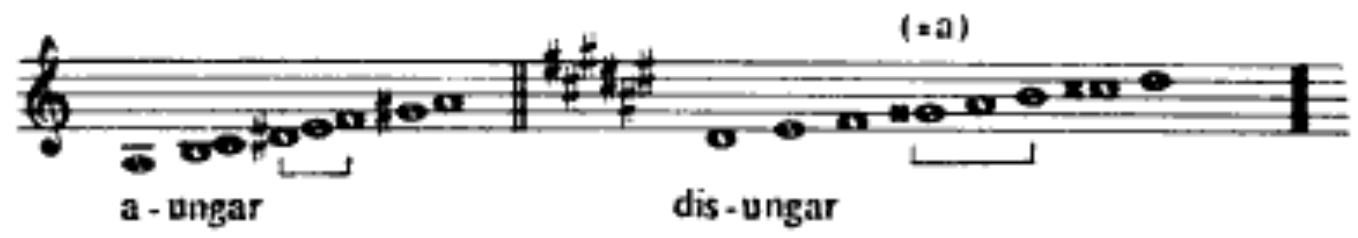

Figure 9. Ungar Scale S5 $^{85}$

The altered harmonic minor scale is the chief characteristic of melodious Hungarian

\footnotetext{
${ }^{82}$ Huneker, 160.

83 "ProQuest Subject Index - Music at JAMES_MADISON_UNIVERSITY," 14, accessed April 1, 2017, http://www.bing.com/cr?IG=CE088B31632D42ABA4085E7D94339998\&CID=0307D522BAA862620A27DF75 BB996386\&rd=1\&h=rCGW6bX8nOujUwPunzD6RtG5z-tYuWn05o-R4slFUmg\&v=1\&r=http\%3a\%2f\%2fgradwo rks.proquest.com

${ }^{84}$ Huneker, 163.

${ }^{85}$ Ibid, 163.
} 
music. It has a melancholic, Oriental flavor which always will be recognized as the Gypsy type. The rhythm is very decisive in most cases, but most of the time in syncopation. This rhythm proves conclusively that the origin of Hungarian music is instrumental, for even in cantabile periods, while the melody follows a more dreamy vein, the syncopations are rarely missing in the accompaniment. At every point we are reminded that dance is a very important source of this music. ${ }^{86}$

In all his 19 Rhapsodies the style, form, constructive idea and application of these ornaments are different, but each is characteristic not only of Hungarian music but also of the rhapsody in particular. ${ }^{87}$

Huneker observes that few pianists can play these Rhapsodies, firstly because they are very difficult and, secondly, because few realize their true meaning. No piano can interpret such music like a Gypsy orchestra. Pianos are adapted simply to our system of harmony, scales, and notes. Oriental music cannot be performed upon them to give it the true, full Oriental effect. ${ }^{88}$

The Hungarian Csárdás is one of the Gypsy dances. It has a specific step (knocking the heels together) which is found in some Oriental dances. In general the Gypsy dances of Europe strongly resemble Oriental dances. ${ }^{89}$

Liszt's 19 Hungarian Rhapsodies are based on Gypsy themes. The syncopated rhythm and the rich ornamentation help to avoid monotony; even more variety is available regarding the tempo, the original "lassan" and "friska" being the most frequent. A moderate and graceful

\footnotetext{
${ }^{86}$ Ibid, $163-164$.

${ }^{87}$ Ibid, 164.

${ }^{88}$ Full text of "Gypsy and Oriental Music",accessed April 25, http://archive.org/stream/jstor-534723/534723_djvu.txt.

${ }^{89}$ Bellman, 14.
} 
allegretto is also used by Liszt, and he tends to graduate the speed of the brilliant finales. ${ }^{90}$ Liszt wrote all of these Rhapsodies after having abandoned his career of traveling virtuoso. Most of them were composed in Weimar. He played them in public but only on rare occasions; for example, he played the 13th Rhapsody at a concert in London, only a few months before his death. $^{91}$

Before I look into the 15th Rhapsody, I believe it is worthwhile to mention the uniqueness and the Hungarian elements in his previous rhapsodies. Perhaps the most famous Rhapsody is No. 2, but No. 10 and No. 6 are also relatively popular.

The 2nd Rhapsody is one of the most widely known pieces of music ever written. This composition was also the one most dreaded by the master himself, whenever an insufficiently prepared pianist tried to play it for him in Weimar. Strangely, the principal subject of the dashing Finale is not an original Hungarian melody, it is an extraction. ${ }^{92}$

The 6th Rhapsody is remarkable for the prevailing joyous mode, the melancholy section being a short one between a Presto and a jolly Allegro. ${ }^{93}$

The 8th Rhapsody has the peculiarity of starting off without any defined rhythm; only after the introduction does the composer indicate two quarters as the meter. The excerpt below illustrates an important characteristic of Gypsy playing: rhythmic flexibility.

The left-hand chord at the end of this excerpt shows how the "orchestra" is clearly

\footnotetext{
${ }^{90}$ Huneker, 165.

91 "Magyar rapszódiák," Wikipedia, February 19, 2017, accessed April 01, 2017, https://hu.wikipedia.org/wiki/Magyar_rapsz\%C3\%B3di\%C3\%A1k. Translated by Helga Scheibert.

92 "Magyar rapszódiák," Wikipedia, February 19, 2017, accessed April 01, 2017, https://hu.wikipedia.org/wiki/Magyar $\operatorname{rapsz} \% \mathrm{C} 3 \% \mathrm{~B} 3 \mathrm{di} \% \mathrm{C} 3 \% \mathrm{~A} 1 \mathrm{k}$.

${ }^{93}$ Bellman, 100
} 
intended to catch the soloist at the end of his improvisation. ${ }^{94}$
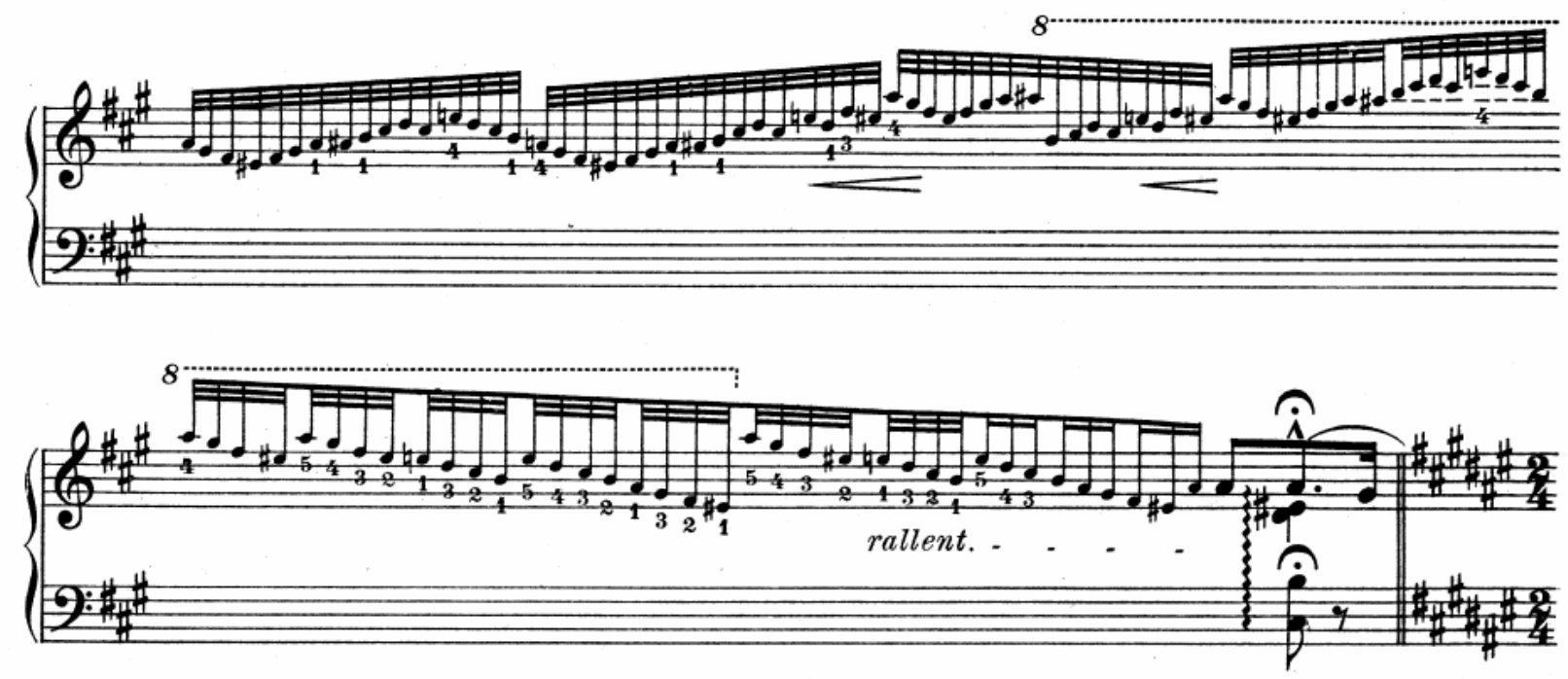

Figure 10. F. Liszt, Hungarian Rhapsody No. 8, m. 40 ${ }^{95}$

Liszt named the 9th Rhapsody Le Carnival de Pesth (Carnival in Budapest). The main theme of the first section, the sempre moderato e capriccio, is unmistakably of Italian character; but when it reappears in the Finale, its character is changed to Hungarian. This interesting and quite extended rhapsody indeed reminds one of a carnival. ${ }^{96}$

The 10th Rhapsody was based on the Csárdás, a traditional Hungarian folk dance which has been discussed previously. Music based on lassan (meaning: slow) demonstrates the sound of Gypsy style as well as Liszt's rich and elegant piano style, while friska style appears in later sections of the work, adding a greater cultural character to the work. This rhapsody reflects the liveliness and passion of Hungarian music, demonstrates Liszt's brilliant piano performing style,

\footnotetext{
${ }^{94}$ Bellman, 101.

95 "Main Page," IMSLP/Petrucci Music Library: Free Public Domain Sheet Music, accessed September 12, 2017, http://imslp.org/.

96 "Magyar rapszódiák," Wikipedia, February 19, 2017, accessed April 01, 2017,

https://hu.wikipedia.org/wiki/Magyar_rapsz $\% \mathrm{C} 3 \% \mathrm{~B} 3 \mathrm{di} \% \mathrm{C} 3 \% \mathrm{~A} 1 \mathrm{k}$. Translated by Helga Scheibert
} 
and also represents Liszt's affection towards his homeland and the Hungarian people. Its main feature is the graceful glissando scale in ascending and descending direction, sometimes in both hands. The loud, booming chords make the piece even more spectacular. ${ }^{97}$

The 11th is one of the shortest rhapsodies, with a drawn-out introduction of changing modes. There is a very striking coda which starts in A minor and goes to F sharp major.

The popularity of the 12th Rhapsody is surpassed only by the Second. This is perhaps the most "rhapsodic" rhapsody, full of characteristic melodies. The 13th Rhapsody consists of only two sections, an Andante and a Vivace. This piece was a favorite of the composer. ${ }^{98}$

It is followed by the very elaborate and quite long 14th Rhapsody. There are splendid contrasts between the Funeral March at the beginning and the Allegretto Zingarese, the dizzying whirl of the Finale. The composer arranged this rhapsody for piano with orchestral accompaniment (Hungarian Fantasia for Piano and Orchestra, S. 123). ${ }^{99}$

I recently performed the 15 th Rhapsody and feel it deserves more discussion. It is hardly a rhapsody in the true meaning of the word, but rather a rhapsodic treatment of the celebrated Rákóczi March.

The form of the piece is $\mathrm{A}-\mathrm{B}-\mathrm{A}$ with an introduction and Coda. Interestingly, there is a cadential transition right before the recapitulation.

The introduction of the piece is very exciting and played at a stormy pace. It is all built on the Gypsy scale: A, B flat, C\#, D, D\#, E, F, G\#. The augmented second may be the only musical

\footnotetext{
${ }^{97}$ Ibid.

${ }^{98}$ Ibid.

99 "Magyar rapszódiák," Wikipedia, February 19, 2017, accessed April 01, 2017, https://hu.wikipedia.org/wiki/Magyar_rapsz\%C3\%B3di\%C3\%A1k.
} 
characteristic to have survived from the period before the Gypsies migrated as far as the western regions of Hungary. The augmented second is not known in original Hungarian music but seems to come from Turkey, where it is a common melodic interval. The Gypsies happily inserted it anywhere, whether it was part of the original melody or not, because the audience loved the highly colored and exotic effect. ${ }^{100}$

The most striking effects in the opening scale are caused by the augmented intervals: F-G sharp (augmented second) and A-D sharp (augmented fourth). The raised fourth gives importance to the fifth degree by acting as a secondary leading tone. It sounds almost as if the artist is improvising — perhaps portraying a storm getting closer and louder.

The end of the opening section is the culminating point of this storm, bringing noisy accents in the octave passage. It is as if the composer is displaying his creativity before reaching the more traditional section of the piece, the March. This March, well known in Hungary, is a patriotic tune of the 18th century. The first version, called Rákóczi-nota (Rákóczi Song), appeared in 1730, composed by an anonymous composer. The song was a lament regarding the misfortune of the Magyars under Habsburg control. The tune called back Francis Rákóczi to save his people. ${ }^{101}$

The melody was Francis Rákóczi’s favorite song. Rákóczi was Prince of Transylvania and leader of the Hungarian uprising against the Habsburgs. Today he is considered a national hero. This nota was a favorite of Hungarian poets such as Petöfi Sándor and Kölcsey Ferenc and was sung during the 1848 revolution. The early version was a popular piece in Hungary during the

\footnotetext{
${ }^{100}$ Bellman, 120.

101 "Rákóczi March," Wikipedia, March 23, 2017, accessed April 01, 2017, https://en.wikipedia.org/wiki/R\%C3\%A1k\%C3\%B3czi_March.
} 
18th century; during the 19th century a more refined version became popular, particularly for military celebrations. The March became an inspirational source for Liszt, Ferenc Erkel and Hector Berlioz (in The Damnation of Faust). Pianist Vladimir Horowitz composed a variation on the "Rákóczi March," using elements of both the Liszt and Berlioz versions. ${ }^{102}$

102 "Rákóczi March," Wikipedia, March 23, 2017, accessed April 01, 2017, https://en.wikipedia.org/wiki/R\%C3\%A1k\%C3\%B3czi_March. Translated by Helga Scheibert 
XV.

Rákóczy-Marsch

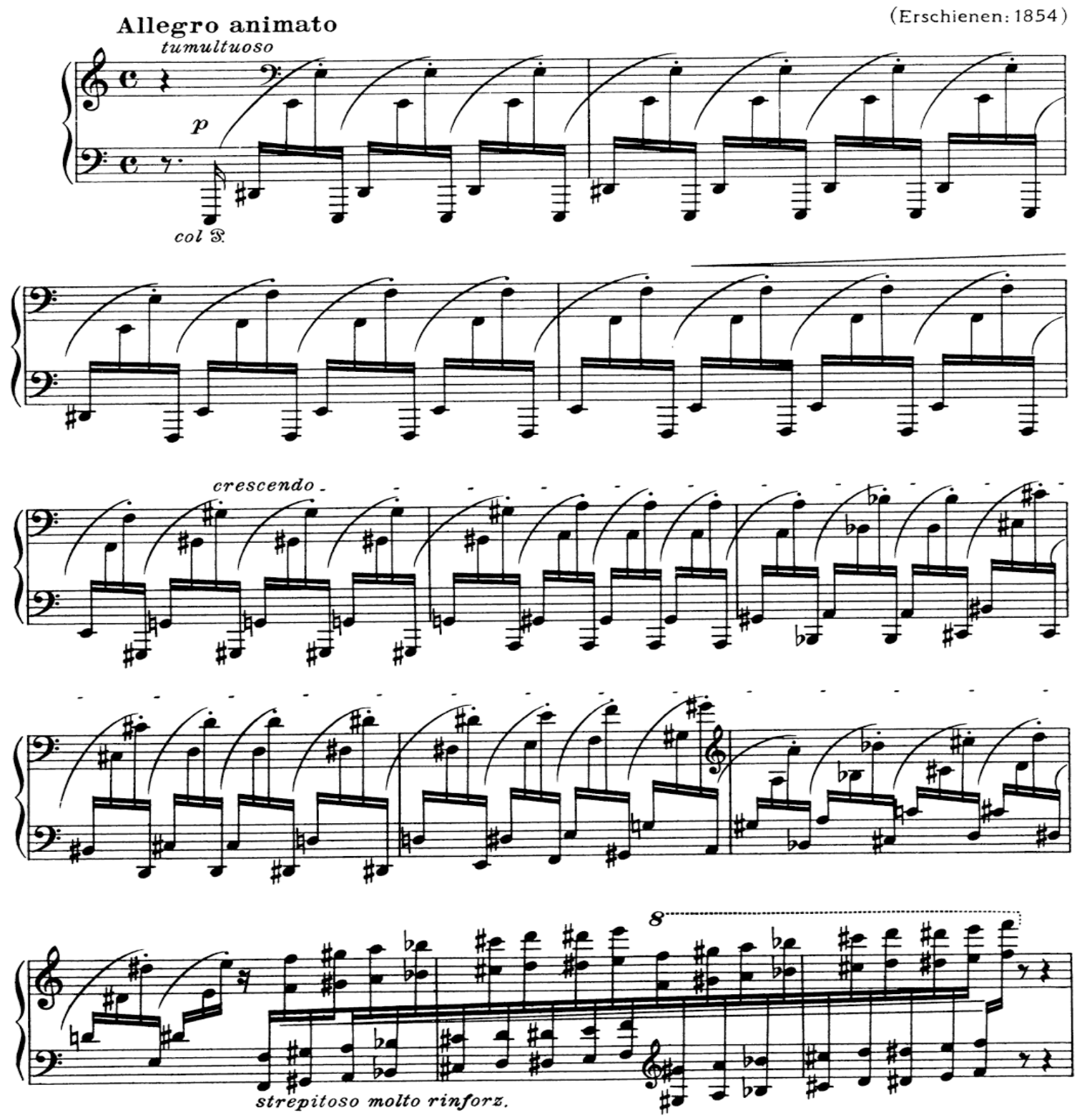

Figure 11. F. Liszt, Hungarian Rhapsody No. 15, mm. 1-13 ${ }^{103}$

The A section is marked Tempo di Marcia animato and the key here is mostly A minor. In

\footnotetext{
103 "Main Page," IMSLP/Petrucci Music Library: Free Public Domain Sheet Music, accessed September 12, 2017, http://imslp.org/.
} 
the figure below we can find triads in F sharp minor beneath the melody in A minor. This axis also dominates in Bartók's Allegro Barbaro: F sharp accompaniment under the melody in A minor. $^{104}$

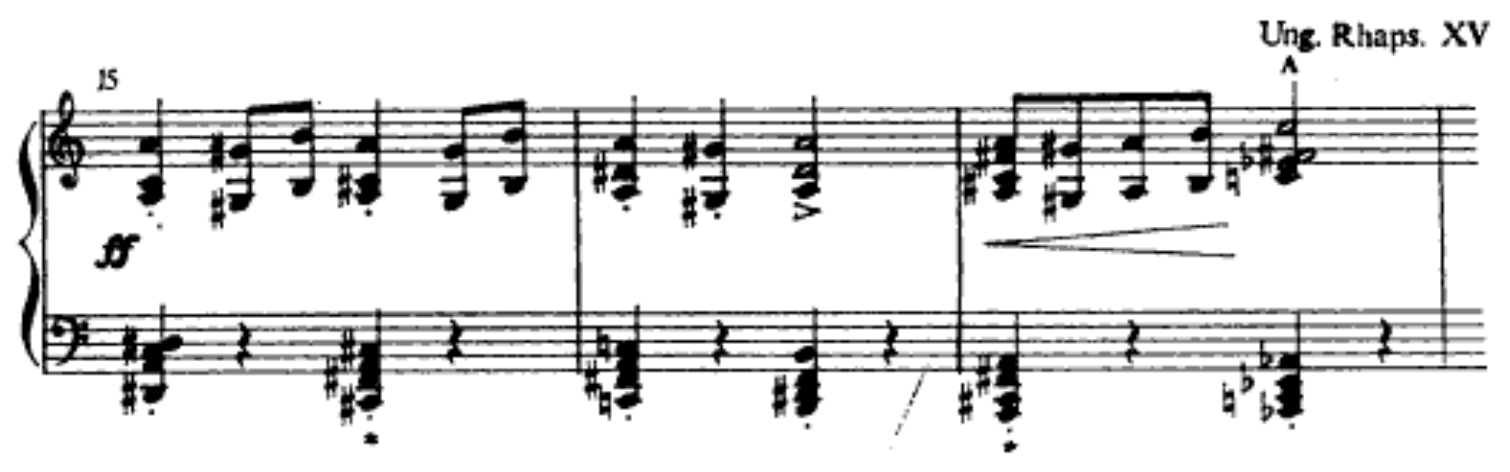

Figure 12. F. Liszt, Hungarian Rhapsody No. 15, mm. 16-19105

As mentioned before, the original version of the March is the Rákóczi Nota which has the peculiar, so-called Kuruc-fourth - a rebounding figure that alternates between the fifth scale degree and upper prime. This figure appears in the opening of a famous song which dates back to the 17th-century Kuruc uprising, the Kuruc being the armed anti-Habsburg rebels, including Hungarian slaves and peasants, between 1671 and 1711. This interval evokes great feelings of Hungarian national pride. Liszt explains: "The use of fourths constitutes a characteristic feature of Hungarian music." 106

\footnotetext{
${ }^{104}$ Bellman

105 "Main Page," IMSLP/Petrucci Music Library: Free Public Domain Sheet Music, accessed September 12, 2017, http://imslp.org/.

${ }^{106}$ Bellman, 122.
} 


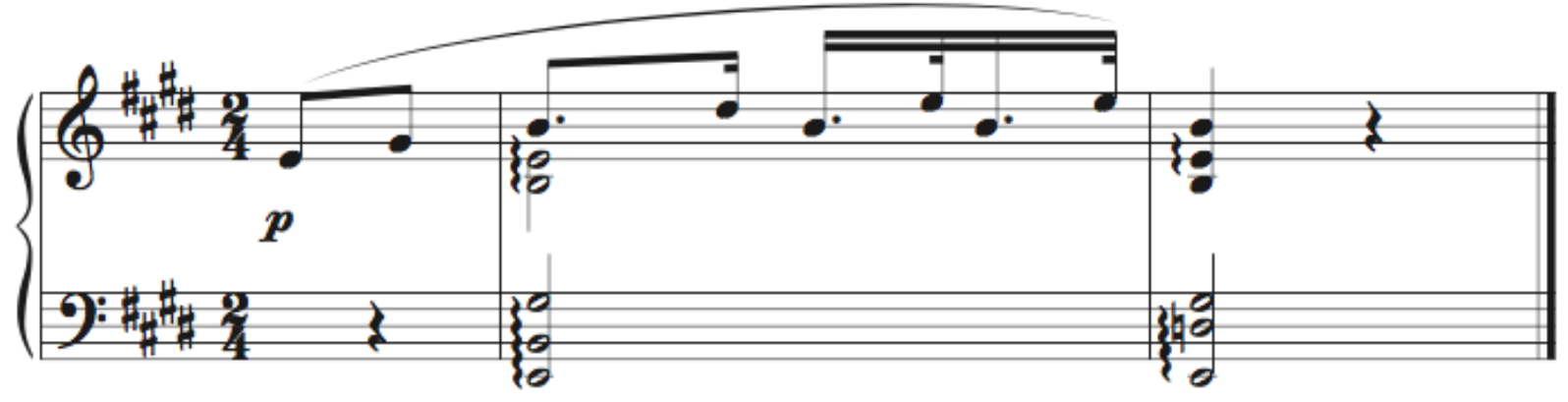

Figure 13. Rákóczi Nota, The Kuruc-fourth ${ }^{107}$

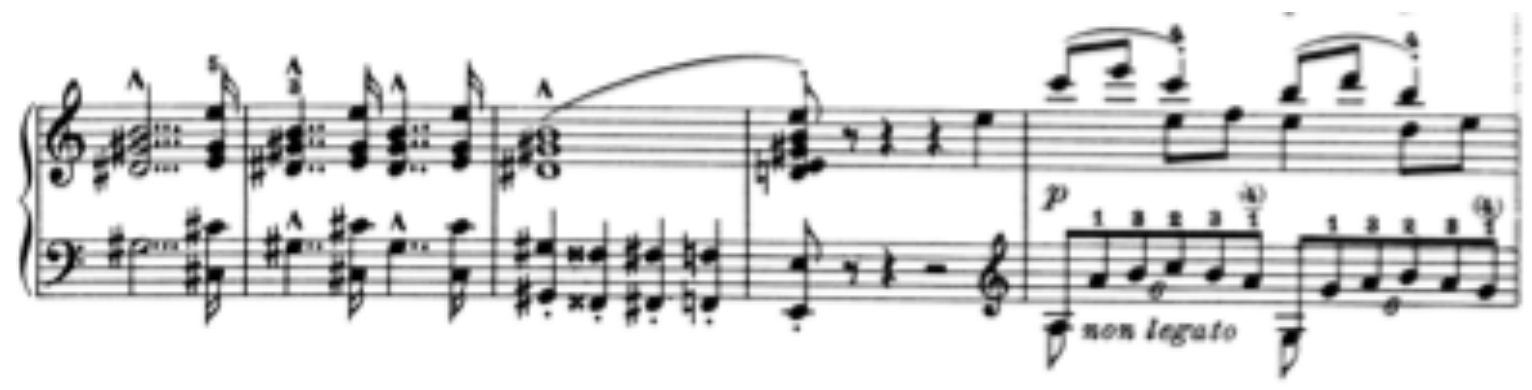

Figure 14. F. Liszt, Kuruc-fourths in Hungarian Rhapsody No. 15. mm. 33-37 ${ }^{108}$

The middle part is dolce, but still marcato, and is in the parallel key of A major. It has 16th-note passages which are virtuosic and evoke the sound of a fiddle. There is a contrasting part, an octave passage played fortissimo, which serves as an answer to the delicate A Major theme.

This section ends with a cadenza which is pure improvisation on the main theme. There are chromatic passages in both hands which gradually increase in sound; these passages are

\footnotetext{
${ }^{107}$ Bellman, 122.

108 "Main Page," IMSLP/Petrucci Music Library: Free Public Domain Sheet Music, accessed September 12, 2017, http://imslp.org/.
} 
reminiscent of the opening. The improvisation starts from sotto voce and tumultuously arrives to fff.

This improvisatory passage reveals many dissonances and chromatic scales, quickly goes up and down the keyboard, and evokes the sound of the cimbalom (see Figure 15). The overall effect is somewhat reminiscent of a Gypsy band showing off. 

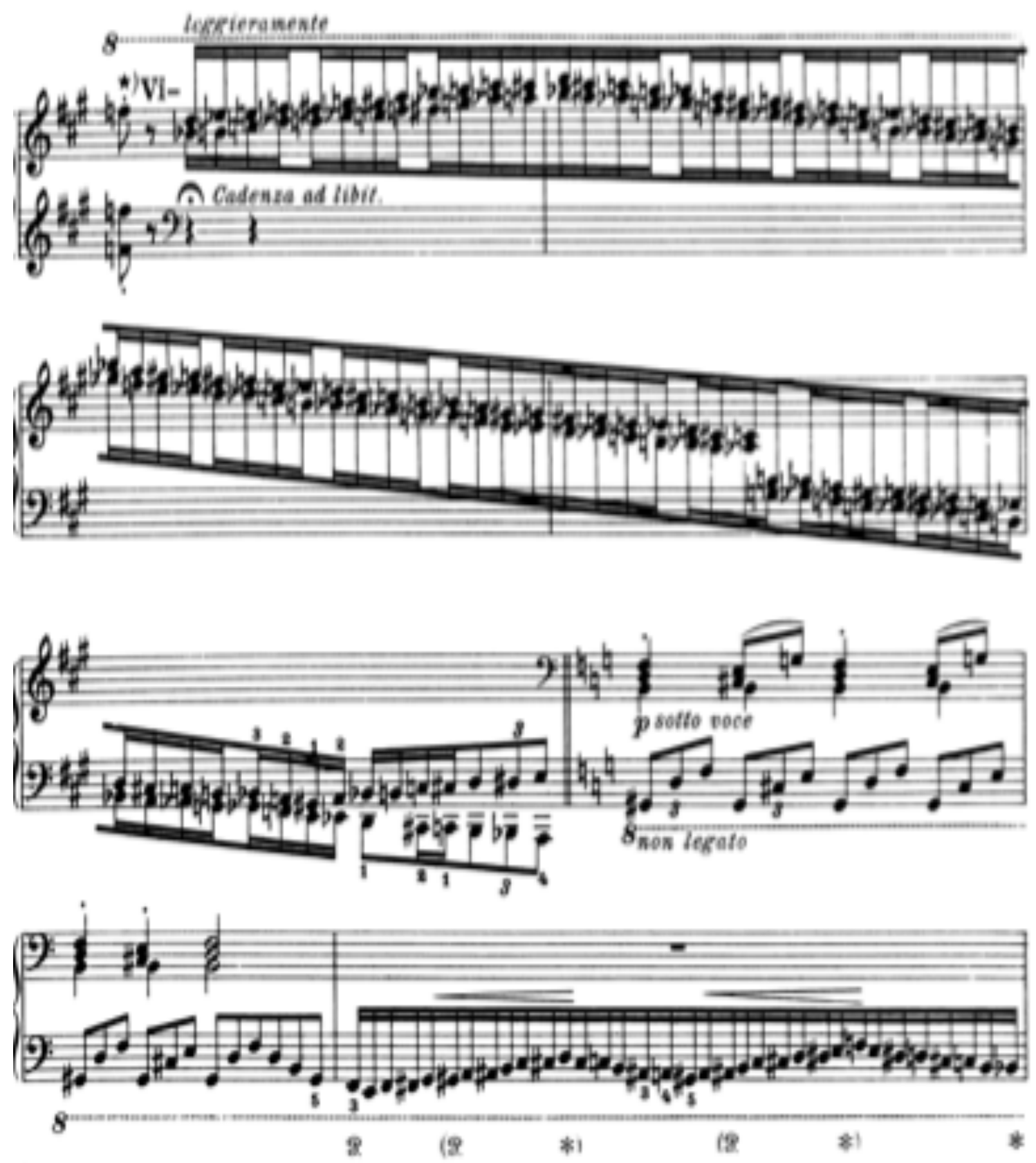

Figure 15. F. Liszt, Hungarian Rhapsody No. 15, mm. 90-97109

109 "Main Page," IMSLP/Petrucci Music Library: Free Public Domain Sheet Music, accessed September 12, 2017, http://imslp.org/. 

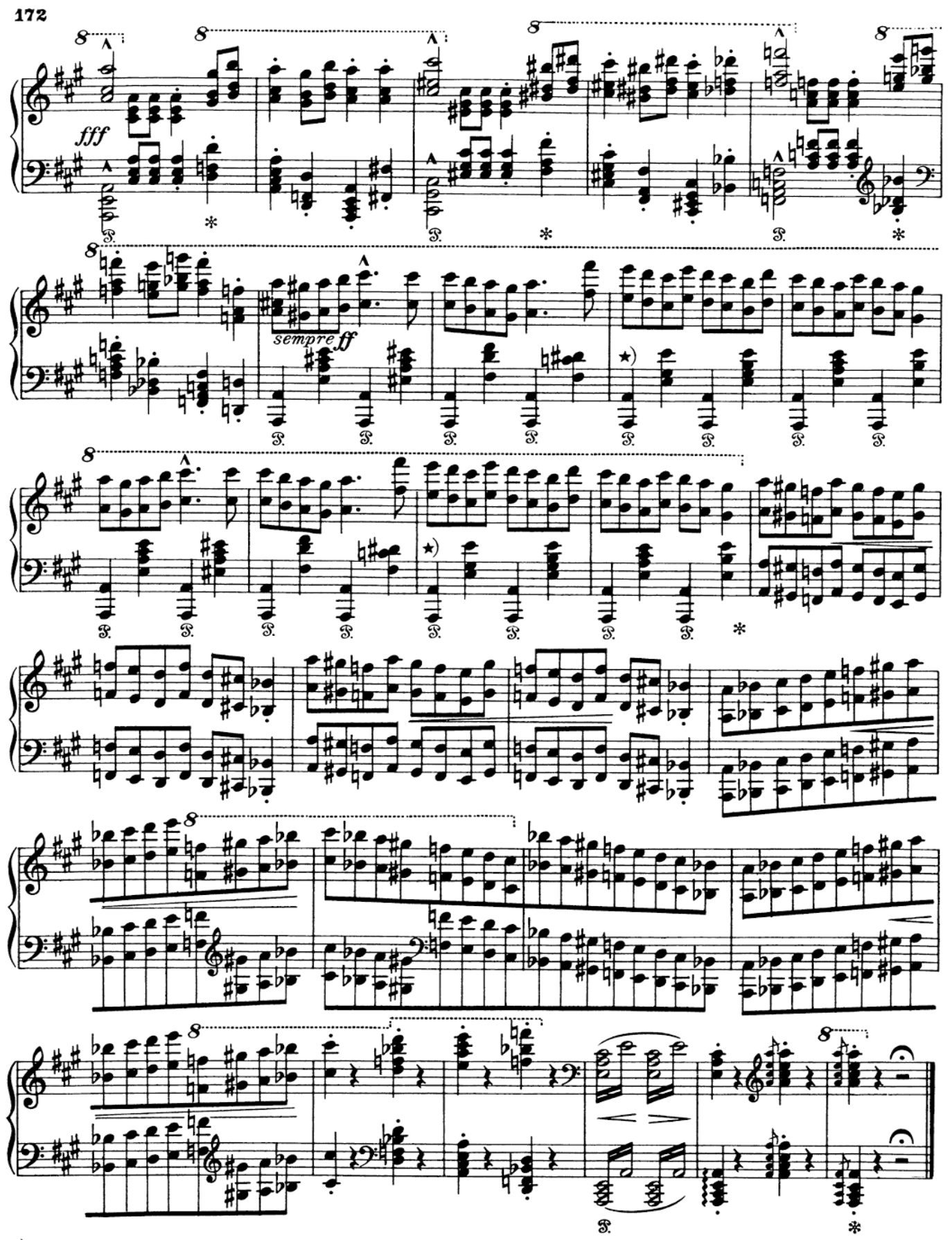

*) Der Herausgeber spielt in seinen Konzerten hier folgenden $\mathrm{Ba} B$ :
*) L'éditeur joue dans ses concerts ici le basse suivant:

*) The Lear joue dans ses concerts ici le basse suivant:

Edition Peters

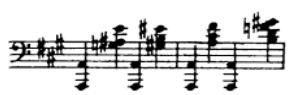

Figure 16. F. Liszt, Hungarian Rhapsody No. 15, mm. 166-194 ${ }^{110}$

110 "Main Page," IMSLP/Petrucci Music Library: Free Public Domain Sheet Music, accessed September 12, 2017, http://imslp.org/. 
This section culminates with a great flourish of octaves, followed by a return of the main melody. Here the glissandos provide a spectacular splash of color and we are reminded again of a Gypsy band employing violin and cimbalom for showy and popular effect. The ending reveals new material, but in similar style, bringing back the Hungarian scale in octaves (see Figure 16). The Finale seems to convey that Rákóczi was truly victorious in battle. 


\section{Chapter V}

\section{Dohnányi}

\section{About the composer.}

Dohnányi was born in Pozsony, Hungary, in 1877. He first studied music with his father, a gifted amateur cellist. At age 17 he moved to Budapest and enrolled at the Academy of Music, where he became a pupil of Istvan Thoman, who was a student of Franz Liszt. Dohnányi followed his star as a pianist. After a few lessons with Eugene d'Albert, another student of Liszt, he traveled all around the world as a concert pianist. He returned home as the most celebrated Hungarian musician since Franz Liszt. ${ }^{111}$

In 1905, he accepted an invitation from the Hungarian violinist Joseph Joachim and moved to Berlin to become head of the piano department at the Berlin Hochschule für Musik. Although he was always best known as a pianist, after his return to Budapest he became increasingly active as a conductor and administrator. ${ }^{112}$ On November 19, 1923, Budapest celebrated a great national event, the 50th anniversary of the union of Buda and Pest. For the anniversary celebration, the city of Budapest commissioned Dohnányi, Bartók, and Kodály to write orchestral works. Dohnányi composed his Festive Overture for this occasion. ${ }^{113}$

\footnotetext{
${ }^{111}$ Dohnányi and Grymes, 15-25.

112 Ibid, 57-58.

${ }^{113}$ Ibid, 81.
} 
By the mid 1930s he was the most powerful man in the musical life of his country: Director of the Liszt Academy, conductor of the Budapest Philharmonic Orchestra, and Head of Music for the Hungarian Radio. ${ }^{114}$

After World War II, his career floundered when he was falsely accused of being a Nazi sympathizer. He and his family were exiled to Austria and then moved to Buenos Aires and finally settled in the United States, where he headed the piano faculty at Florida State University. He died February 9, 1960, and was buried in Tallahassee, Florida. ${ }^{115}$

\section{Variations on a Hungarian Folk Song Op. 29.}

Dohnányi always maintained a deep love for his motherland. During World War I he spent much of his time giving charity concerts in Hungary. These were mostly for the benefit of soldiers who had been wounded fighting in the battlefield and were suffering in hospitals. $^{116}$

He wrote his Variations on a Hungarian Folk Song in 1917, around the same period when he returned from Berlin to Budapest, as a teacher and also as the director of the Music Academy. Unlike Bartók and Kodály, Dohnányi didn’t mine as much Hungarian folk music for his compositional vocabulary. This has likely complicated his place in history somewhat, in that he was the chief architect of Hungary's musical landscape but has inevitably been overshadowed in this respect by those composers who more literally gave Hungary its musical voice. Dohnányi's music instead celebrates the Romantic legacy of Johannes Brahms and Robert Schumann.

\footnotetext{
${ }^{114}$ Dohnányi and Grymes, 85.

${ }^{115}$ Ibid, 189-202.

${ }^{116}$ Ibid, 68.
} 
We can greatly hear the influence of Brahms in these variations. Dohnányi was a friend and admirer of Brahms. When Brahms died on April 3, 1897, Dohnányi, accompanied by three other colleagues, was sent to Vienna by the Academy to attend the funeral. He was chosen to say goodbye at the burial. ${ }^{117}$

While Dohnanyi’s nationalistic composition Ruralia Hungarica has a bigger reputation, his first work based on a traditional Hungarian melody was the Variations on a Hungarian Folk Song, Op 29. In this work Dohnányi combined his nationalism with his fascination for the theme-and-variations form. The theme is introduced in a very simple way, in unmetered block chords and arpeggiated figures that terminate each of the folk song's two halves. ${ }^{118}$ The melody is built on a pentatonic scale $\mathrm{E}-\mathrm{G}-\mathrm{A}-\mathrm{B}-\mathrm{D}$. The interval of a fourth, between $\mathrm{B}-\mathrm{E}$ (m. 1-2, Fig. 17), is typically found in Old Style Hungarian folk songs.
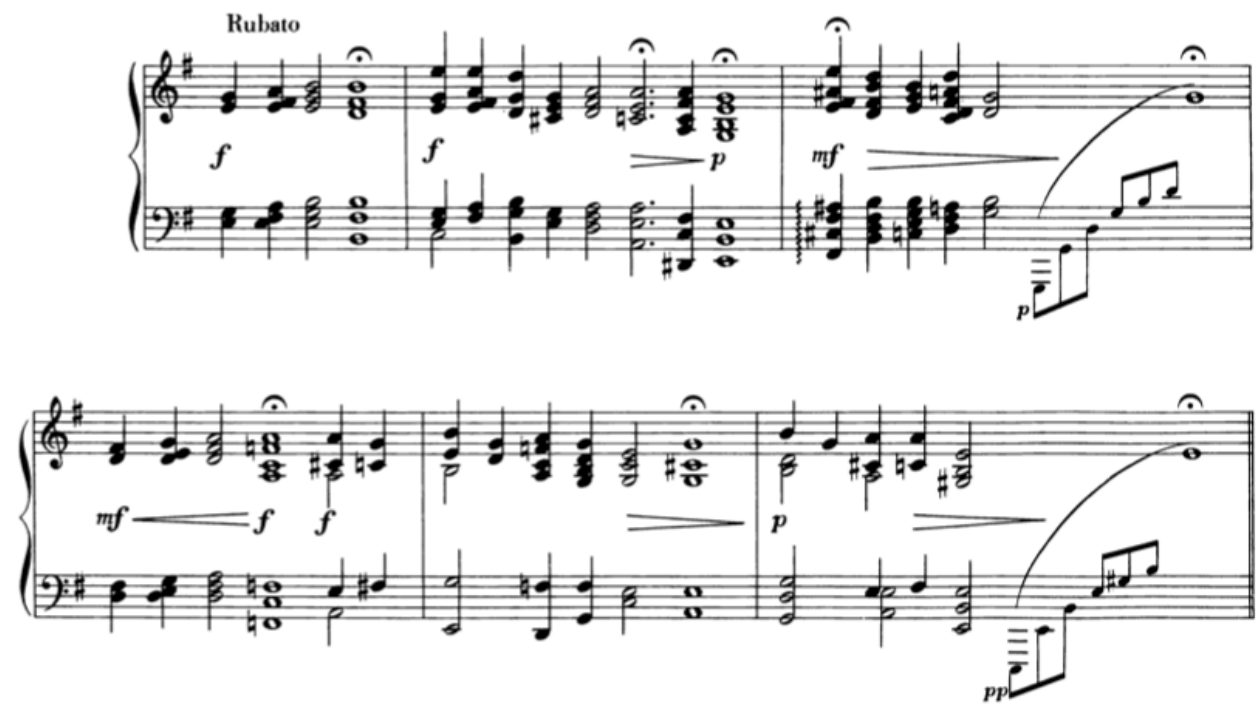

Figure 17. E. Dohnányi, Variations on a Hungarian Folk Song, mm. 1-6 ${ }^{119}$

\footnotetext{
${ }^{117}$ Dohnányi and Grymes, 22.

${ }^{118}$ Variations on a Hungarian Folksong, Op 29 - Hyperion Records - CDs, MP3 and Lossless downloads, accessed October 24, 2017, https://www.hyperion-records.co.uk/tw.asp?w=W15362.

119 "Main Page," IMSLP/Petrucci Music Library: Free Public Domain Sheet Music, accessed September
} 
There is one Old Style Hungarian folk song that is very similar to Dohnányi’s version. This is a psalm type folk song which has the characteristic of " $\mathrm{C}-\mathrm{D}-\mathrm{E}$ " in the beginning, which can be found in other Finno-Ugric and Asian folk songs. It also has the characteristics of note repetition and rich ornamentation, following the movement of speech and avoidance of big jumps. As we can see in the musical example below, the largest interval is a fourth. Most of these psalm songs are parlando or rubato and can nowadays still be heard in Transylvania among Székely and Csango people and in Moldova. Bartók also used the same melody in the Eight Hungarian Folk Songs, in the second song, called Istenem, Istenem Áraszd meg a Vizet (meaning “God, Give Us Rain.”) ${ }^{120}$

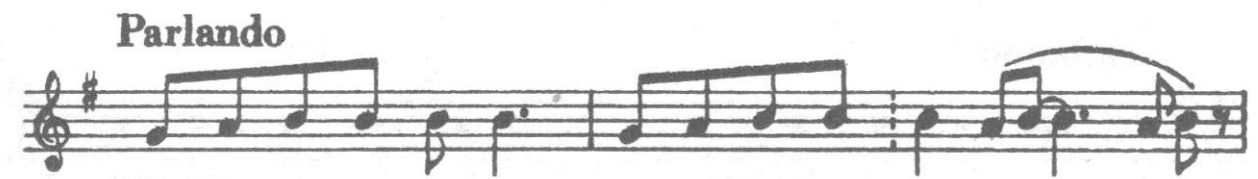

Szi - vár-vány ha-va - sán fel-nö́tt roz-ma - ring-szál

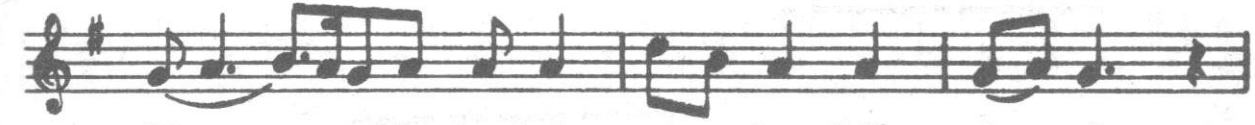

Nem szere-ti he-lyét, el a-kar buij - dos-ni.

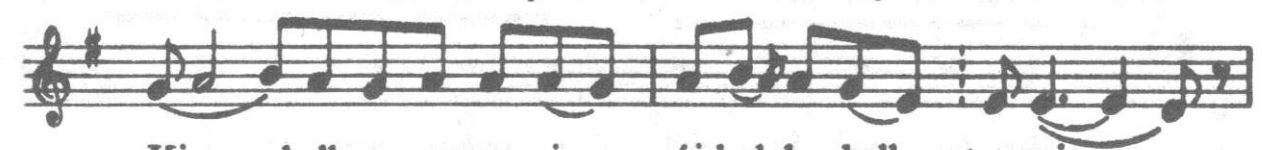

Ki kell on-nan venni s új helybe kell ten-ni,

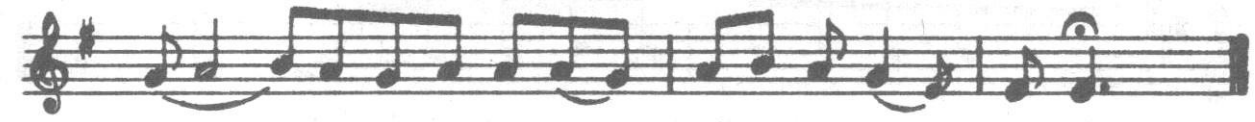
Ki kell onnan ven-ni súj helybe kell ten-ni.

Figure 18. Szivárvány Havasán ("On the Mountain Top") ${ }^{121}$

12, 2017, http://imslp.org/.

${ }^{120}$ Www.nagykunreformatus.hu/content_g/.../regi_stilus.html.

121 Www.nagykunreformatus.hu/content_g/.../regi_stilus.html. 
The text is metaphoric, describing someone who is unhappy and lonely on the top of a mountain:

"On top of mountain there is a rosemary

She feels lonely and sad.

Wants to go far away to a better place

Far away to a better place."

The lyrics alone are beautiful and Dohnányi creates a sublime atmosphere by transforming the opening motive and adding accompaniment.

The opening variations alternate between slow and fast tempos (Dolce, Vivace, Andante, Vivace), with the the third variation imitating the Hungarian folk dulcimer known as the cimbalom. ${ }^{122}$ The bass arpeggiation could easily be intended for cimbalom and the top voice sounds as if it could be a good fit for a fiddle, conveying a distinctly Hungarian atmosphere reminding me of Liszt's Hungarian Rhapsodies.

${ }^{122}$ Variations on a Hungarian Folksong, Op 29 - Hyperion Records - CDs, MP3 and Lossless downloads, accessed October 24, 2017, https://www.hyperion-records.co.uk/tw.asp?w=W15362. 

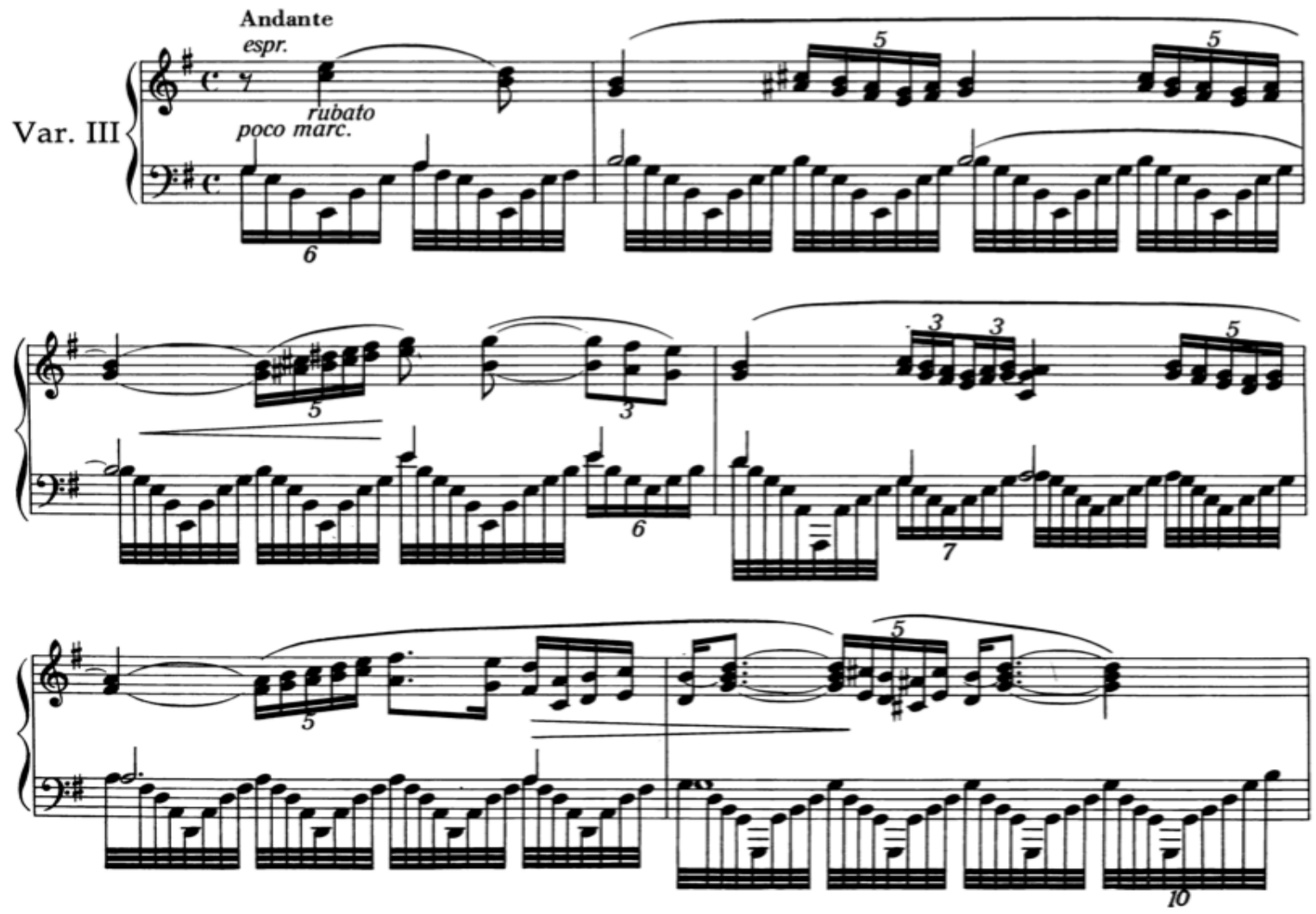

Figure 19. E. Dohnányi, Variations on a Hungarian Folk Song, Variation III, mm. 1-6 ${ }^{123}$

The fifth variation, marked "Tranquillo," recalls the sound of bells and requires both hands to play each of the bass and treble voices in order to fill out the rich harmonies. ${ }^{124}$ These massive chords are difficult to play, and to me this variation evokes the style of Rachmaninoff.

123 "Main Page," IMSLP/Petrucci Music Library: Free Public Domain Sheet Music, , accessed September 12, 2017, http://imslp.org/.

${ }^{124}$ Variations on a Hungarian Folksong, Op 29 - Hyperion Records - CDs, MP3 and Lossless downloads, , accessed October 24, 2017, https://www.hyperion-records.co.uk/tw.asp?w=W15362. 


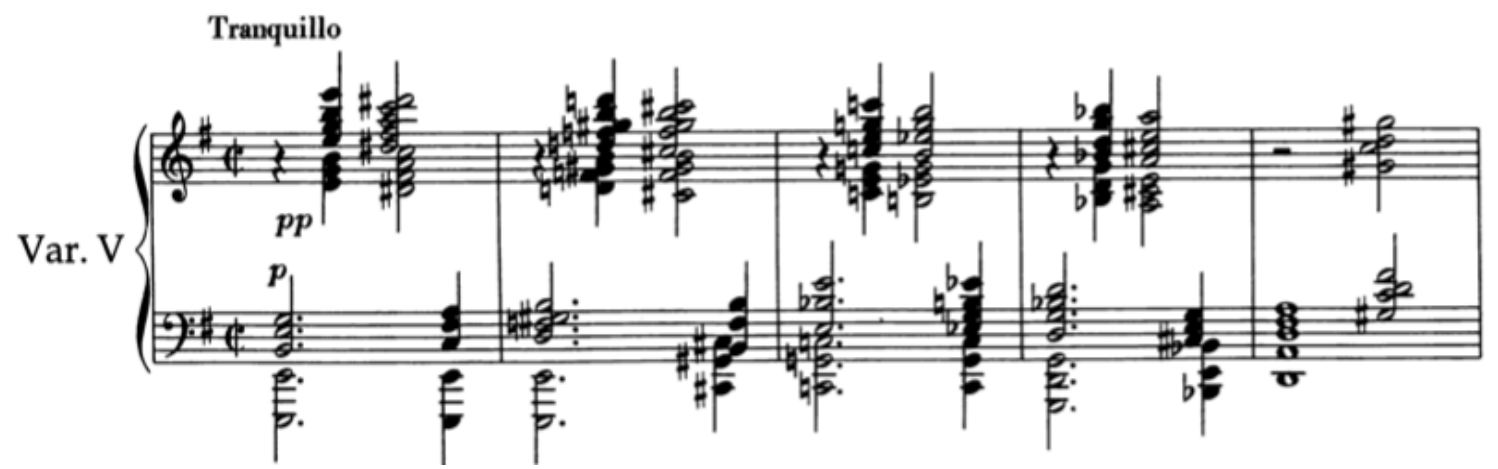

Figure 20. E. Dohnányi, Variations on a Hungarian Folk Song, Variation V, mm. 1-4 ${ }^{125}$

Variations six through nine gradually build up in character and virtuosity, similar to the fourth variation. Variations VII, VIII, and IX have the dance-like feeling of a fast csardas played by a Gypsy band. These three variations are extremely difficult to play, as the tempo is fast and the texture is thick, with loud running octaves and chords. See Figure 21.
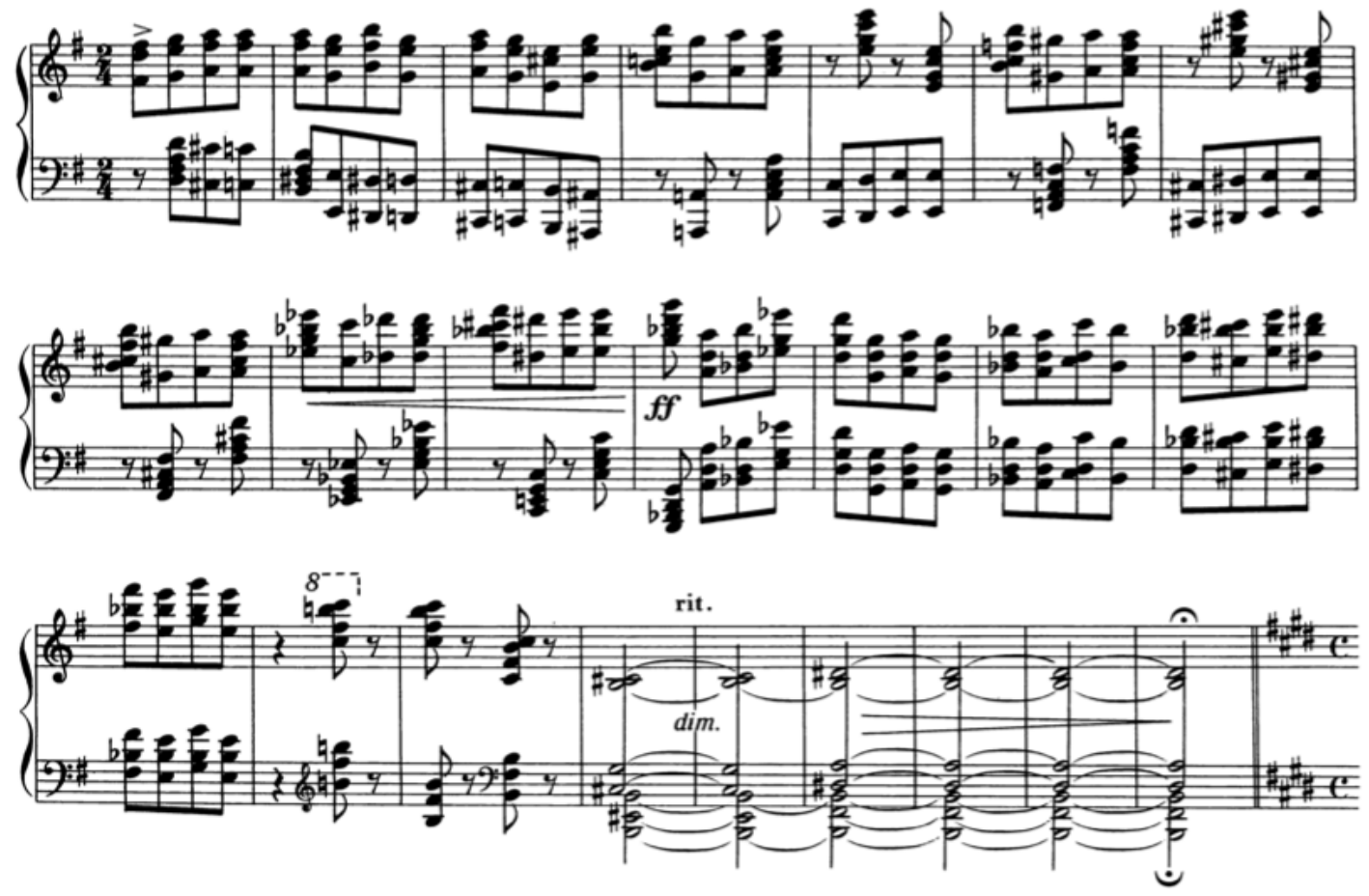

125 Ibid. 
Figure 21. E. Dohnányi, Variations on a Hungarian Folk Song, Var. IX, mm. 35-57 ${ }^{126}$

The tenth variation, marked "Andante Rubato," is highly ornamented and contrapuntal, with multiple voices; but the folk song is clearly stated throughout. Here it sounds like each member of the Gypsy orchestra is showing off: the main melody is supported by stringed instruments and the accompaniment sounds like double bass and cimbalom. The work ends with a coda which recalls the serenity of the theme. Even simpler octaves replace the opening chords, with extended arpeggios at the ends of each phrase. ${ }^{127}$

This sounds like an improvisation, highlighting some of the notes from the main melody. This ending, with all its beautiful harmonies and rests, sounds like a sublime meditation. The melancholy sentiment returns, but there might still be hope for the rosemary's "better life."
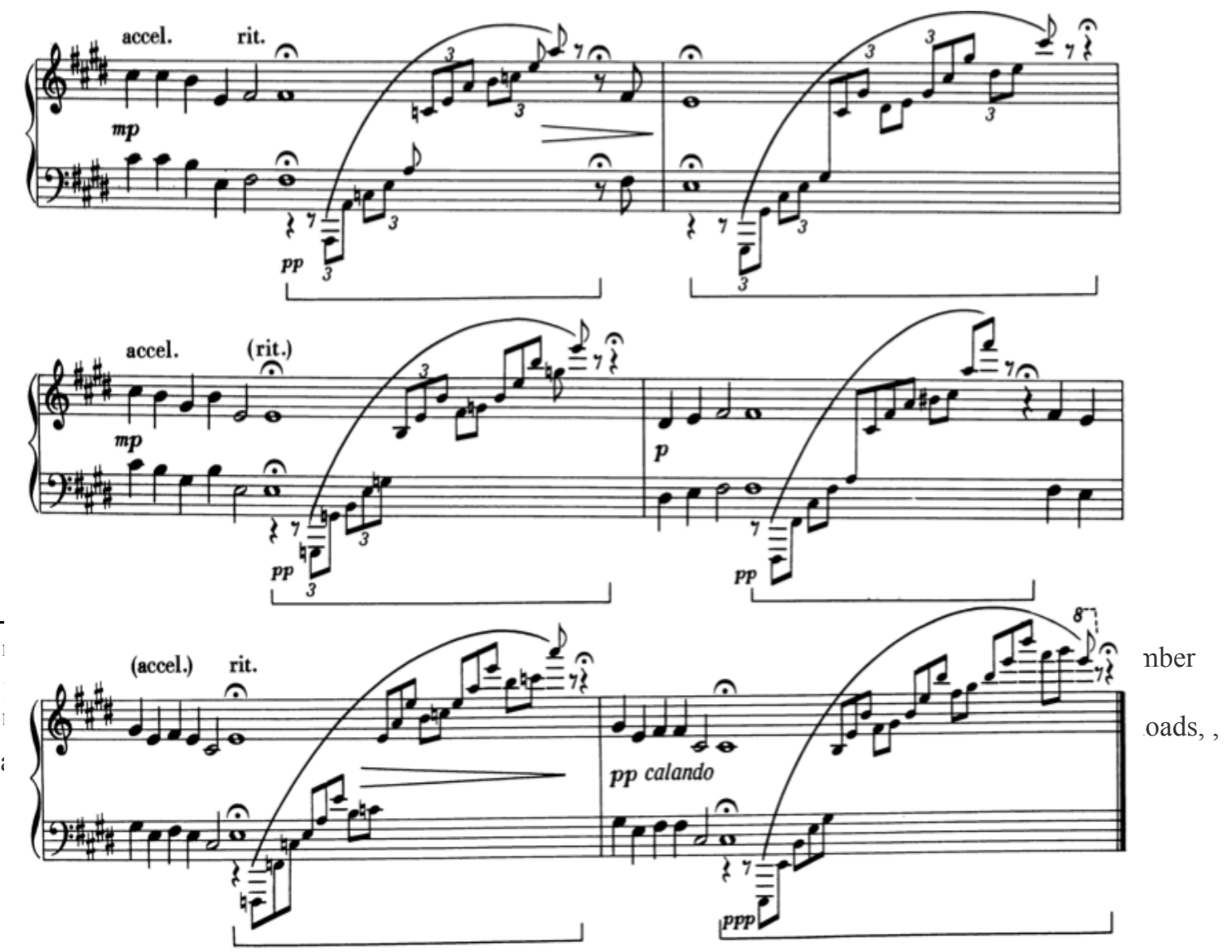
Figure 22. E. Dohnányi, Variations on a Hungarian Folk Song, Variation X, mm. 19-24 128

128 "Main Page," IMSLP/Petrucci Music Library: Free Public Domain Sheet Music, , accessed September 12, 2017, http://imslp.org/. 


\section{Chapter VI}

\section{Bartók}

\section{About the composer}

Béla Bartók was born on March 25, 1881, in Nagyszentmiklos, which is in a district that is now part of Romania. He began piano lessons at the age of five with his mother and was composing actively by the time he was ten. As a young child he was considered a musical prodigy, being able to play numerous songs on piano by memory. By the age of nine he was writing down his own piano compositions. ${ }^{129}$ He states in his Autobiography:

Before I was eighteen, I had acquired a fairly thorough knowledge of music from Bach to Brahms. All this time I was busy composing and was under the strong influence of Brahms and Dohnányi, who was four years my senior. ${ }^{130}$

Later on he decided to pursue advanced musical studies at the Budapest Academy of Music and revealed a Hungarian national identity that would become central to his life as a composer. It was the pianist and composer Erno Dohnányi who encouraged the young Bartók to come to Budapest to study at the Academy of Music with Dohnányi’s own piano professor, István Thoman, who had studied with Franz Liszt. ${ }^{131}$

This identification with his Hungarian heritage led Bartók to his decision to remain in Hungary when most Hungarian musicians of the time were moving to Vienna to pursue music.

\footnotetext{
${ }^{129}$ Suchoff. Béla Bartók: Life and Work, 14-15.

${ }^{130}$ Bartók Béla. The Life of Béla Bartók (Place of publication not identified, 1949), 3-7.

${ }^{131}$ Suchoff. Béla Bartók: Life and Work, 21.
} 
In 1907, Bartók became a piano professor at the Budapest Academy of Music, a position which allowed him to stay active as a pianist and also make tours around Europe. ${ }^{132}$

\section{Bartók as an ethnomusicologist}

He felt that his musical language as a composer was influenced by Romantic composers such as Brahms, Liszt, and Straus, especially in the Rhapsody Op. 1 for piano and Scherzo Op. 2 for piano and orchestra. ${ }^{133}$ In 1904, after his graduation from the Budapest Academy of Music, Bartók showed his interest in folklore for the first time.

Encouraged by his fellow composer and compatriot Zoltán Kodály (1882-1967) he decided to make a thorough study of authentic folk music. He began to go out into the countryside to hear and write down folk melodies; in the process, he discovered that the music of the farmers and peasants was the true folk music of Hungary. The Gypsy music of the time was mostly an urban and largely commercial adaptation of numerous Western influences. ${ }^{134} \mathrm{He}$ pointed out in an important article:

For an artist it is not only right to have his roots in the art of some former times, it is a necessity. Well in our case it is peasant music which holds our roots. ${ }^{135}$ Using a wax cylinder phonograph, Bartók recorded the singing of local village people, later transcribing the results for study and categorization. Bartók is quoted as saying:

In order to obtain older songs we had to turn to old people, old women in particular whom, quite naturally, it was difficult to get to sing. They were ashamed to sing before a strange gentleman...

Nonetheless, the two composers had the highest level of commitment and compassion:

\footnotetext{
${ }^{132}$ Suchoff. Béla Bartók: Life and Work, 53.

133 Nissman, 2.

134 Ibid, 9.

${ }^{135}$ Béla Bartók and Benjamin Suchoff. Béla Bartók Essays. (Lincoln: University of Nebraska Press, 1993 ), 346.

${ }^{136}$ Béla Bartók and Benjamin Suchoff, 332.
} 
We had to live in the most wretched villages under the most primitive conditions, as it were, and had to make friends of the peasants and win their confidence... Yet despite all this, I must admit that those days which I spent in the villages among the peasants were the happiest days of my life. ${ }^{13}$

Kodály and Bartók working together helped lay the foundation for the discipline we know as ethnomusicology. Throughout his life Bartók maintained an active interest in these studies, and wrote numerous ground-breaking books and articles.

In the summer of 1904, Bartók overheard a girl named Lidi Dósa singing a melody that had unusual qualities. She was from the Székely region, which is in the south-east corner of Transylvania. Lidi was a servant of a Budapest family who stayed in the same hotel with Bartók. One of the songs, Piros Alma Leesett a Sárba ("The red apple fell into the dirt"), impressed Bartók, so he asked her to sing it again so that he could notate it. In 1970, Lidi Dósa mentioned in an interview: ${ }^{138}$

On one occasion, he heard me singing, I was singing to the child...The song pleased Bartók, and he asked me to sing it again and again because he wanted to note it down. When he had taken it down, he went to the piano and played it. He then called me and asked if he was playing it properly. It was exactly as I sung it...I had to sing continually, however, he only wanted to hear the ancient village tunes! He only liked those I had learned from my grandmother.

Later, his arrangement of Piros Alma was published in the magazine Magyar Lant ("Hungarian Lute").

Bartók realized that he had chanced upon an ancient melody type unknown until then, which was different from the Hungarian folk songs heard in Budapest. This led him to realize that there were many authentic Hungarian folk songs to be investigated in the villages. ${ }^{140}$

\footnotetext{
${ }^{137}$ Béla Bartók and Benjamin Suchoff, 332.

${ }^{138}$ Yu-Young Lee, "Béla Bartók's Eight Hungarian Folk Songs for Voice and Piano: Vocal Style as Elaborated by Harmonic, Melodic, and Text Factors." PhD diss. (University of Texas Austin 2006), 2.

${ }^{139}$ Yu-Young Lee, 2.

${ }^{140} \mathrm{Ibid}, 3$.
} 
After hearing Lidi Dósa’s songs, Bartók revealed some of his priorities in a letter to his sister in December, 1904:

Now I have a new plan: to collect the finest Hungarian folk songs and raise them, adding the best possible piano accompaniments, to the level of art-song. ${ }^{11}$

The Székely people performed melodies which have structural elements of old Hungarian peasant songs, specifically the characteristic central Asia type of pentatonic scale: a symmetrical structure consisting of the first, minor third, fourth, fifth and minor seventh degrees $(\mathrm{E}-\mathrm{G}-\mathrm{A}-\mathrm{B}-\mathrm{D}){ }^{142}$
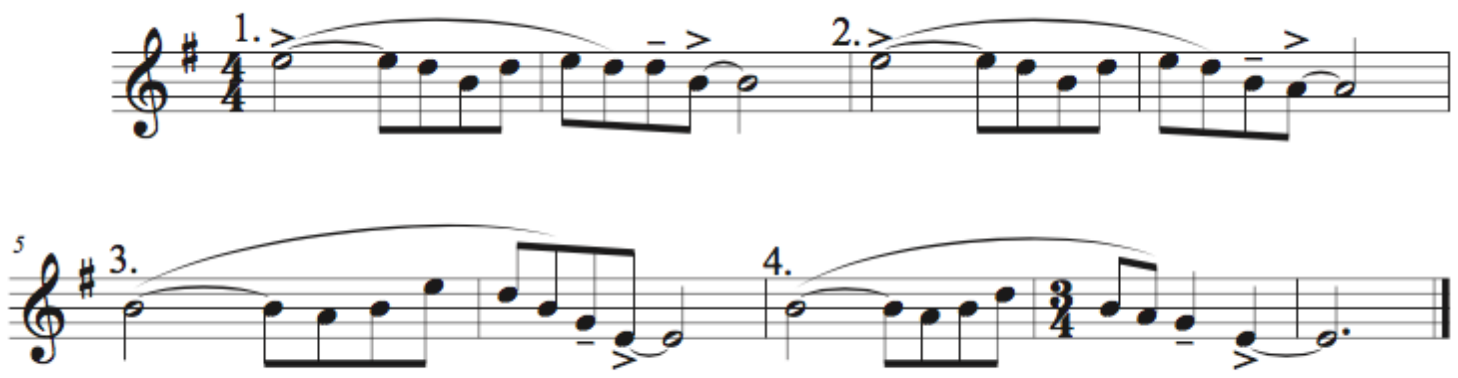

Figure 23. B. Bartók, Evening in Transylvania No. 5 from Ten Easy Pieces for Piano ${ }^{143}$

Another characteristic of the Székely folk songs is tempo rubato, recitativo parlando, rich ornamentation, the non-rounded quaternary $(\mathrm{ABCD})$ section structure, and the eight-syllable text line in each section. There is no tonic-dominant relationship and the melodic contour has frequent leaps in fourths. ${ }^{144}$

\footnotetext{
${ }^{141}$ Amanda Bayley. The Cambridge companion to Bartók. (Cambridge: Cambridge University Press, 2007$), 99$.

142 Bartók, 130.

${ }^{143}$ Ibid, 130.

${ }^{144}$ Suchoff. Béla Bartók: A Celebration, 130.
} 
Bartók further mentions that the ancient pentatonic scale that the Hungarians brought with them from central Asia into the Danube Basin in the 9th century, as well as the variety of old Greek modes, "freed me from the tyrannical rule of major and minor keys and eventually led to a new conception of the chromatic scale, every tone of which came to be considered of equal value and could be used freely and independently." ${ }^{145}$

In 1907 he developed five levels of complexity for using his source material.

1. The folk tune is the "jewel" and the added parts function as "mounting."

2. The folk tune and added parts are treated equally.

3. The folk tune appears as a musical "motto."

4. The melody appears as an imitation of a folk tune.

5. Neither folk tune nor imitation is used; there is only an atmosphere of folk music. $^{146}$

Bartók's ethnomusicological work resulted in the collection and transcription of thousands of vocal and instrumental melodies. Having a superb musical ear, he immediately detected foreign influences and stylistic differences in Hungarian village music; as a result he extended his field trips to Hungarian-controlled areas containing Slovak, Romanian, and other minorities. He focused on such aspects such as scale type and permutations, rhythmic aspects, variation forms, performance peculiarities, and instrumental color. ${ }^{147}$

\footnotetext{
${ }^{145}$ As cited in Suchoff. Béla Bartók: Life and Work, 168.

${ }^{146}$ Benjamin Suchoff. Béla Bartók: A Celebration, 4-5.

${ }^{147}$ Ibid, 127.
} 
Bartók researched the folk music not only of Hungary, but also of the Slavic countries, Turkey and North Africa. His eclectic and mature style draws upon many different, even opposed sources, but synthesizes them within a completely consistent and personal idiom. ${ }^{148}$ Sonatina (1915).

1915 could well be called Bartók’s year of Romanian folk song arrangements. Although he did compose pieces of Romanian origin, it was in this year that he wrote such works as the Sonatina, Romanian Christmas Carols, Romanian Folk Dances. ${ }^{149}$

The Sonatina, in three movements, is based on five Romanian folk tunes that Bartók collected from the peasants in a Transylvanian village. In 1931 it was transcribed for orchestra as Transylvanian Dances. ${ }^{150}$ The original types of dances used in the Sonatina are not indicated; however the titles refer to the characteristics of the individual movements: "Bagpipers," "Bear Dance," and "Finale." 151

Bartók says of this piece:

The Sonatina was originally conceived as a group of Romanian folk dances for the piano; the three movements were selected from the group and given the name Sonatina. The first movement, "Bagpipers," is a dance - these are two dances played by two bagpipe players, the first by one and the second by another. (Also described in original version as ardeleana, a round dance in two parts, usually performed by two women and a man.) The second movement is called "Bear Dance" - this was played for me by a peasant violinist on the G and D strings, on the lower strings in order to have it more similar to a bear's voice. Generally the violin players use the $\mathrm{E}$ string. And the last movement contains also two folk melodies played by peasant violin players. This music has a joyful and playful character but also virtuosic, Lisztian--especially in the Finale.

\footnotetext{
${ }^{148}$ Benjamin Suchoff. Béla Bartók: A Celebration, 127.

${ }^{149}$ Gillies, 147.

${ }^{150}$ Nissman, 104.

${ }^{151}$ Gillies, 148.

${ }^{152}$ Nissman, 104.
} 


\section{1. "Bagpipers"}

This movement, marked Allegretto, contains several characteristic features of Romanian instrumental folk music, including the moving bagpipe part, which is a dominant feature of the style, and the unique modal character of the work with which it is closely connected. There is a combination of a Lydian fourth degree (G\#) and Mixolydian lowered seventh degree (C), which plays an important role in Bartók's music of Romanian, Transylvanian character. The music literature often refers to this type of scale as "acoustic" or "Bartókian" because of its natural and unique character. The uncertain quality of certain degrees of the scale is another important characteristic. When analyzing Romanian folk music, Bartók always pointed out this phenomenon and considered it also to be an important element of his own compositional technique. ${ }^{153}$

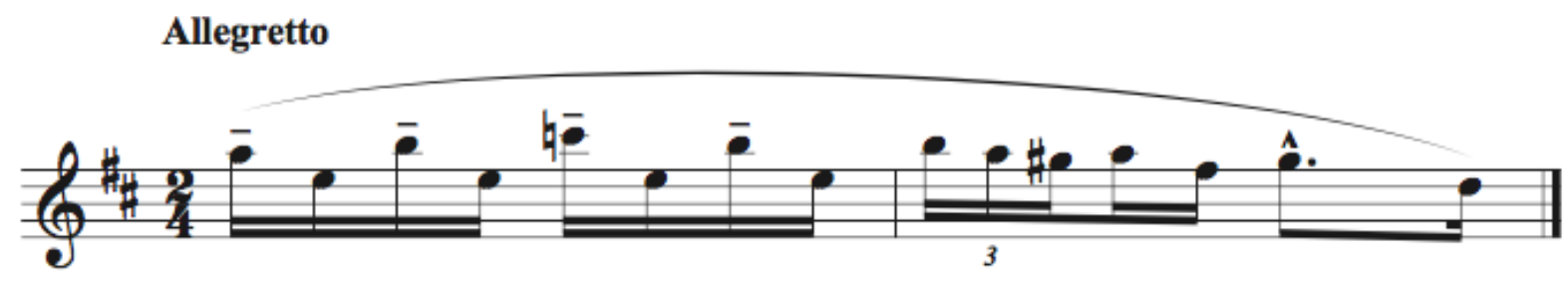

Figure 24. B. Bartók, 1st Movement from Sonatina, mm. 1-2 $2^{154}$

As was described in chapter three, the bagpipe is an instrument very often used in Transylvania. The most characteristic feature of the Hungarian bagpipe is the double-bored chanter. One chanter bore (melody pipe) plays the melody within an octave range and has a "flea hole," a common feature in Eastern bagpipes: the top hole on the chanter is very small, and

\footnotetext{
${ }^{153}$ Gillies, 149.

154 "Main Page," IMSLP/Petrucci Music Library: Free Public Domain Sheet Music, accessed September 12, 2017, http://imslp.org/.
} 
uncovering it raises the pitch of any other note by approximately a semitone, making the Hungarian $d u d a$ highly chromatic over its range. The second chanter, called the contra pipe, has a single finger hole and plays either the lowest tonic or drops to the dominant. For example on a pipe in A the contra pipe sounds either A or E. The contra pipe provides rhythmic accompaniment to make the pedal point more interesting. ${ }^{155}$

Bartók carefully indicates the pedaling desired for maximum effect; these long pedals create the droning sound of bagpipes. There is a significant difference between the two bagpipers from segments A and B, which are based on two different folk songs. ${ }^{156}$ As seen in the examples below, the second player has a more difficult job because of the faster tempo, meter changes and more complicated rhythms.

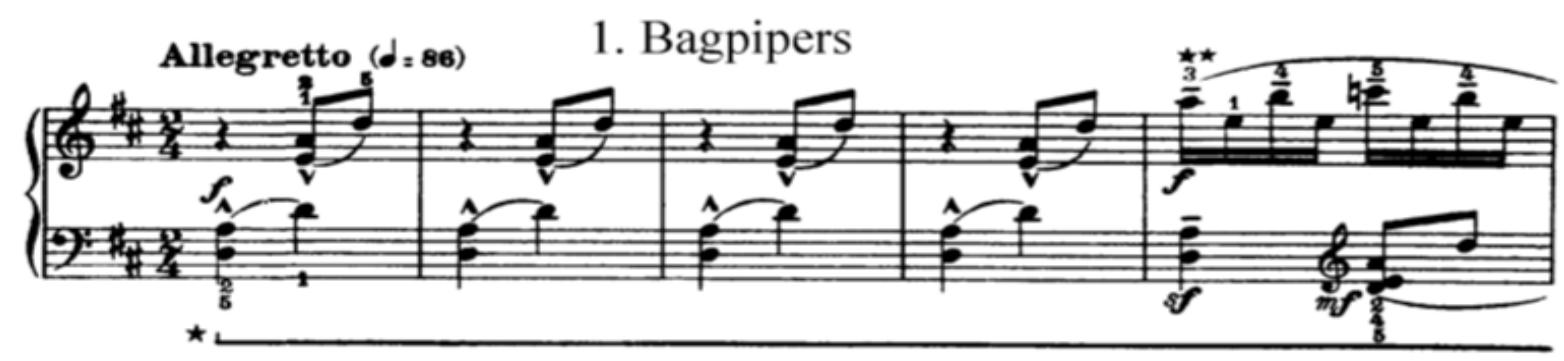

Figure 25. B. Bartók, 1st Movement from Sonatina, segment A, mm. 1-4 ${ }^{157}$

\footnotetext{
155 "Duda," Wikipedia, April 04, 2017, accessed April 04, 2017, https://en.wikipedia.org/wiki/Duda.

156 Nissman, 105.

157 "Main Page," IMSLP/Petrucci Music Library: Free Public Domain Sheet Music, accessed September 12, 2017, http://imslp.org/.
} 


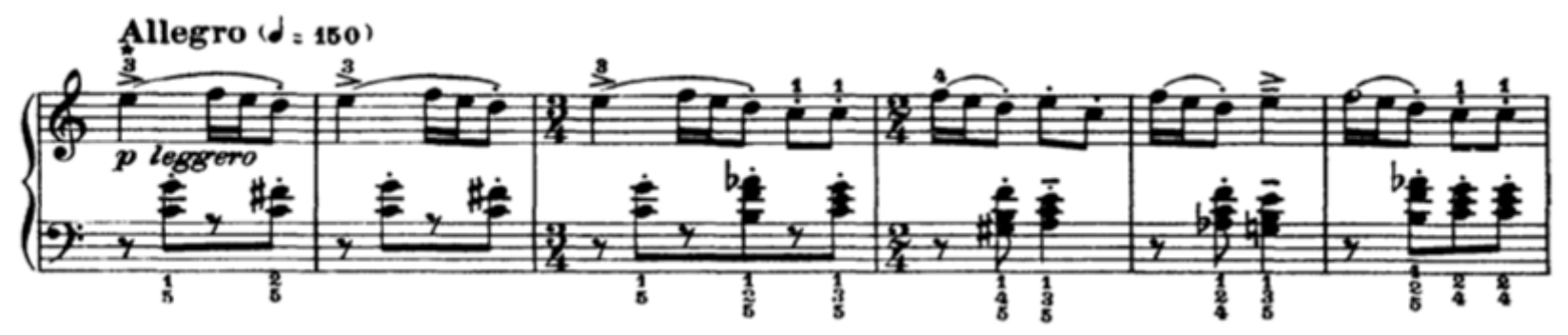

Figure 26. B. Bartók, 1st Movement from Sonatina, segment B. mm. 21-26 ${ }^{158}$

The final statement is forte with offbeat accents. Interestingly, the movement ends on the dominant, which is the key of the next movement: A minor.

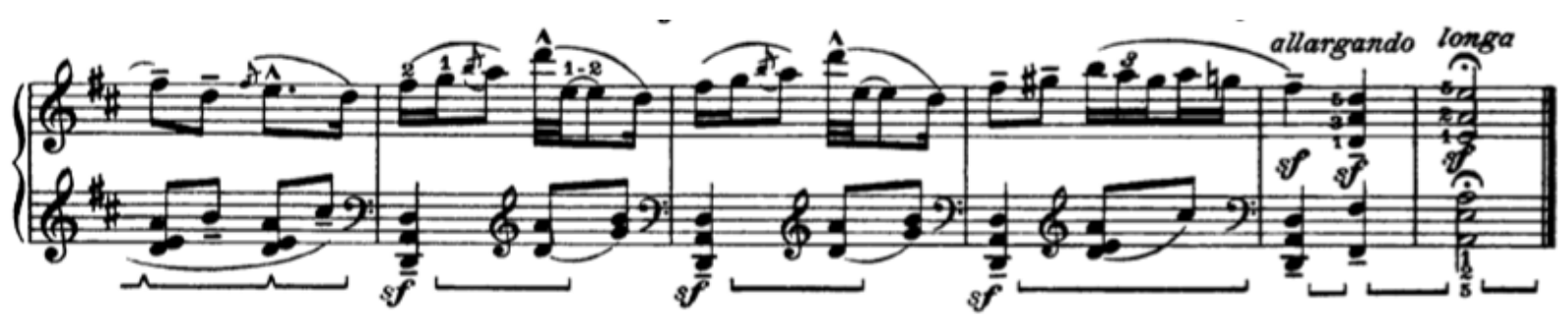

Figure 27. B. Bartók, 1st Movement from Sonatina, mm. 61-66 $6^{159}$

2. "Bear Dance"

The offbeat accents in the left hand express the heaviness and humor of this movement; we can almost see the bear pacing back and forth within the restriction of his chain. Here the short notes balance with the bear's weight and give a dance-like character. ${ }^{160}$ The character conveys the impression of a slower csardas. The top line sounds as if Bartók may have intended this part for a furulya, Hungarian flute. Perhaps another indicator of Hungarian folk music is the seventh steps in the bass and seventh chords in the right hand, along with the stepwise motion in the melody line.

\footnotetext{
158 "Main Page," IMSLP/Petrucci Music Library: Free Public Domain Sheet Music, accessed September 12, 2017, http://imslp.org/.

${ }^{159}$ Ibid.

${ }^{160}$ Nissman, 105.
} 


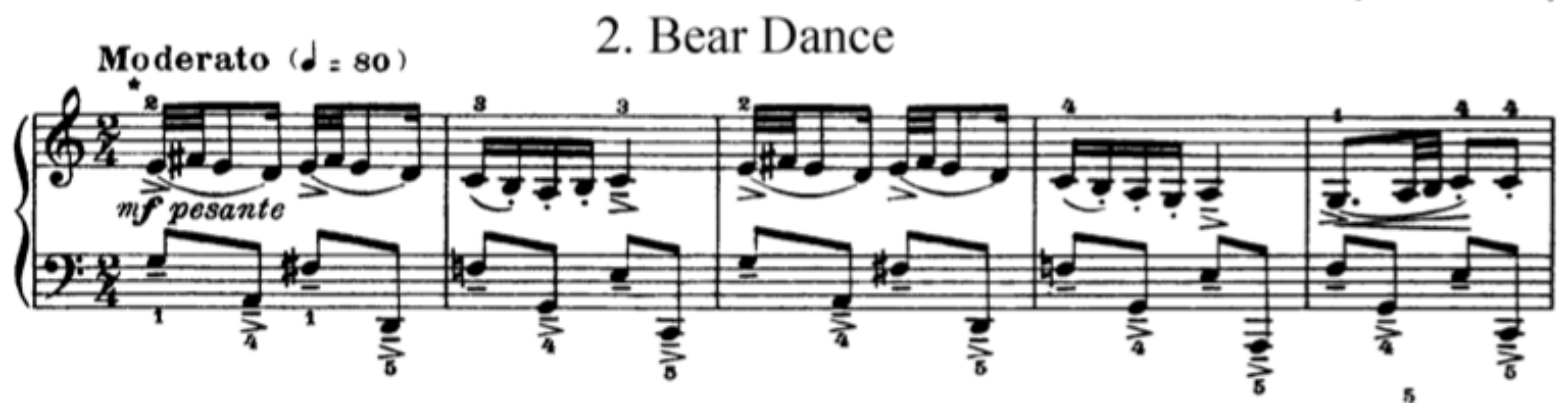

Figure 28. B. Bartók, 2nd Movement from Sonatina, mm. 1-5 ${ }^{161}$

The key here switches between G Major and C Major, but the ending settles down to C Major as the bear becomes tired and slows down.

3. "Finale"

Regarding the Finale, Nissman states:

The first dance here is also described in its original version as a turca, danced by a man wearing a specific type of animal head with a movable beak; as he dances, he operates the beak with a string, which produces a clattering sound made in the rhythm of the dance. This dance was traditionally performed during the winter solstice. $^{162}$

The theme is varied. Every time the theme is stated, the bass line has a change. The accompaniment has a characteristically syncopated rhythm, which later changes to regular eighth notes. The markings are very rich with different types of accent marks, slurs, and staccatos.

Although the movement is marked Allegro Vivace, we see has many tempo changes. The melodies used in segment A (first dance) and B (second dance) are similar. They have the typical Hungarian Old-style folk song's stepwise motion and smaller intervals not exceeding the fourth. The most often used rhythms in the melody are short, short, long. See Figure 29 and 30.

\footnotetext{
161 "Main Page," IMSLP/Petrucci Music Library: Free Public Domain Sheet Music, accessed September 12, 2017, http://imslp.org/.

${ }^{162}$ Nissman, 104.
} 

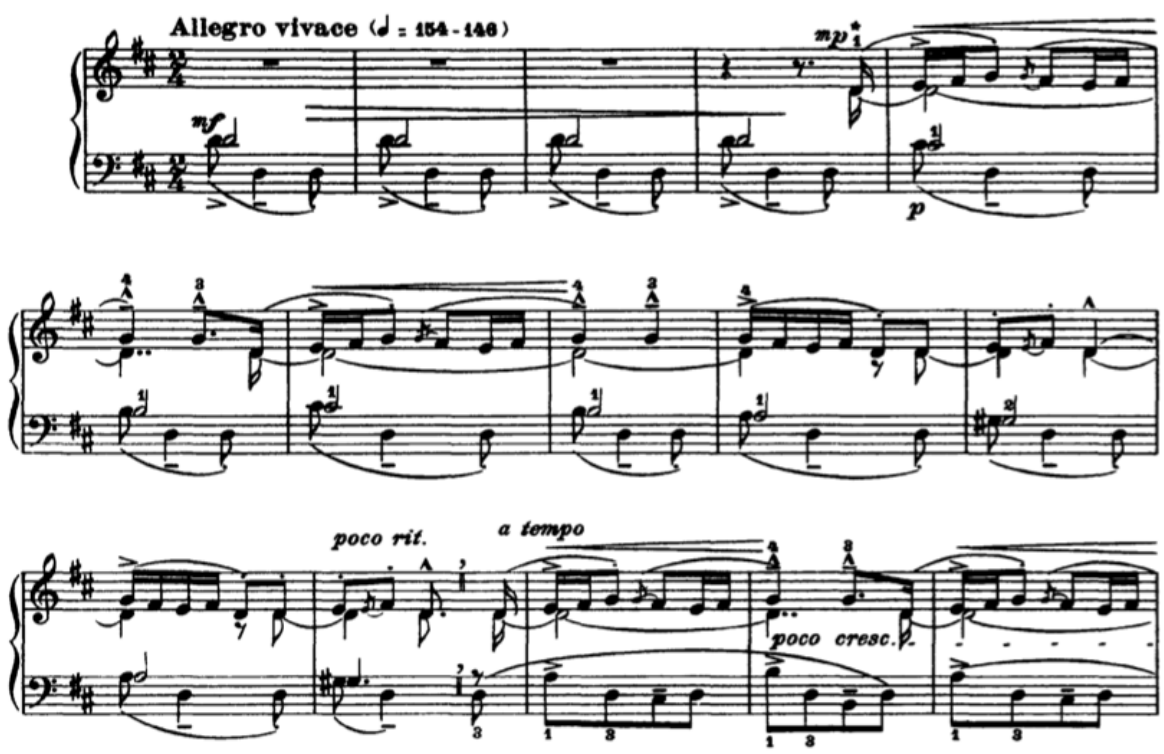

Figure 29. B. Bartók, 3rd Movement from Sonatina, segment A, mm. 1-15 ${ }^{163}$
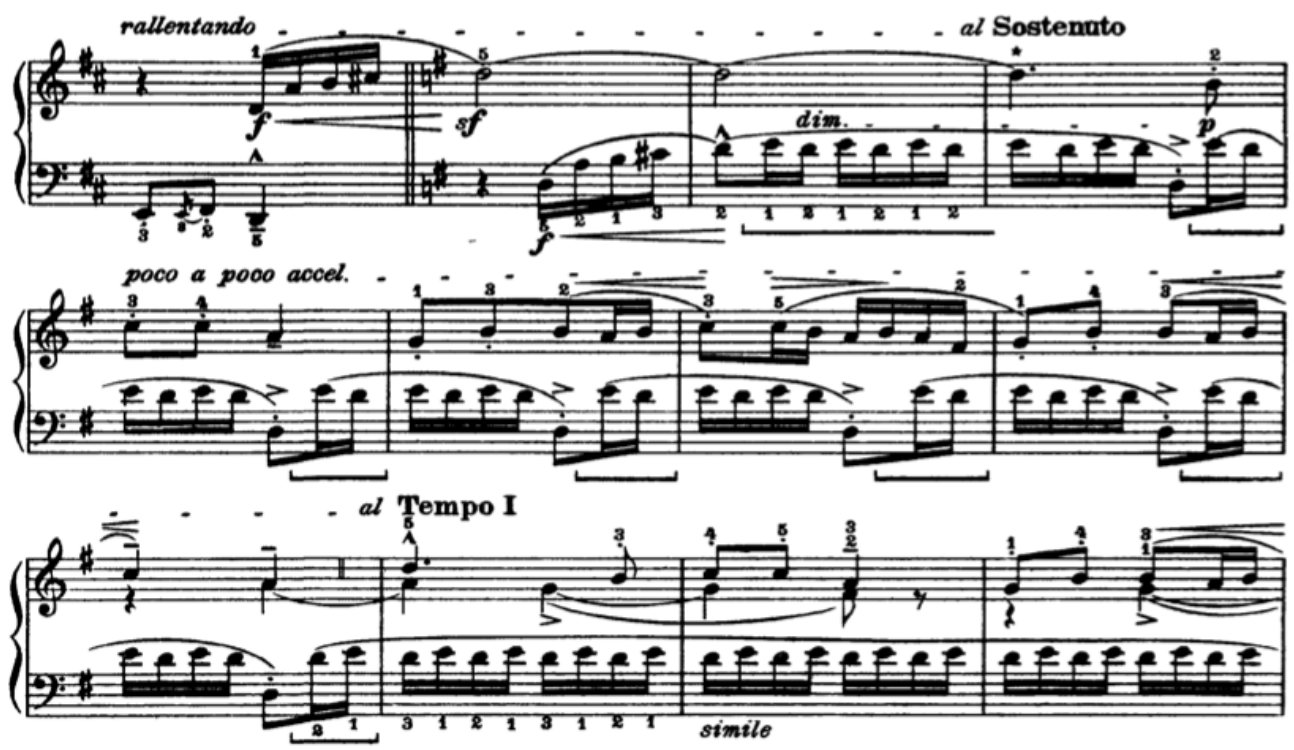

Figure 30, B. Bartók, 3rd Movement from Sonatina, segment B, 37-48 ${ }^{164}$

Interestingly the Coda is a mix of both themes, which forms a harmonious ending. The sound increases more and more, starting pianissimo and growing all the way to fortissimo.

163 "Main Page," IMSLP/Petrucci Music Library: Free Public Domain Sheet Music, accessed September 12, 2017, http://imslp.org/.

164 Ibid. 
The dramatic ending is extremely effective, with repeated short-short-long motives and a sforzando final chord.
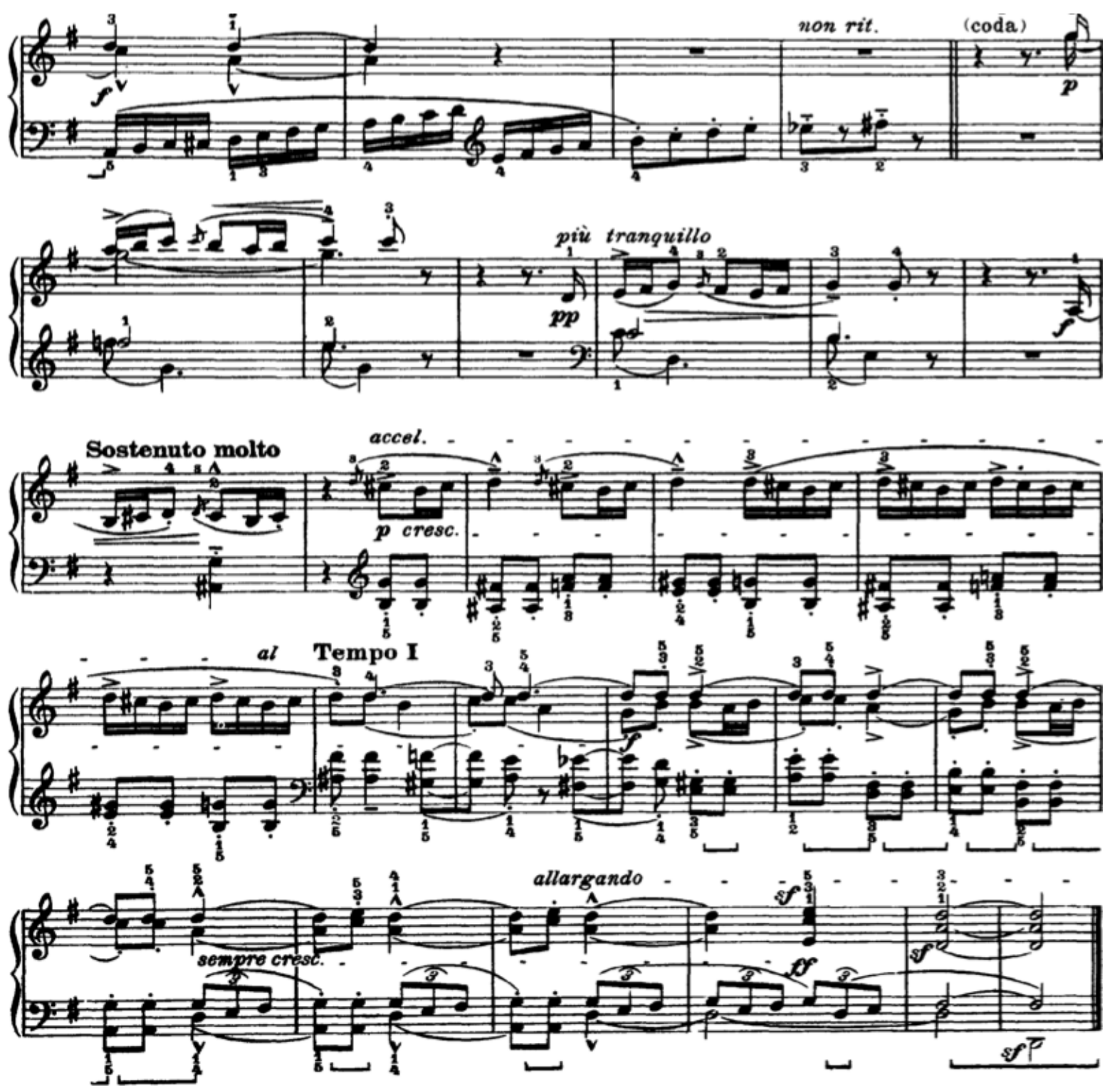

Figure 31. B. Bartók 3rd Movement from Sonatina, mm. 76-102 ${ }^{165}$

Romanian Folk Dances (1915).

165 "Main Page," IMSLP/Petrucci Music Library: Free Public Domain Sheet Music, , accessed September 12, 2017, http://imslp.org/. 
Compared with the Two Romanian Dances, Op. 8a (1909-1910), Bartók’s later series entitled Romanian Folk Dances is a simpler collection. The main difference between the two is that the earlier work is a monumental, boundless dance fantasy based on Bartók's own themes of Romanian character, whereas the later collection is a folk-music arrangement in the narrow sense. ${ }^{166}$

This set of six pieces is based on fiddle tunes. Its material had been collected by the composer during his tours to the counties of Mureş and Bihor between 1910-1912. These counties are located in Transylvania; therefore, it is questionable whether the dances are originally Romanian or Hungarian, since Transylvania used to belong to Hungary. The Old-style folk music from Transylvania offered Bartók a number of elements that were attractive, not found in newer Hungarian folk music and, moreover, stimulating to his further renewal of twentieth-century art music. Above all, the instrumental folk music in Transylvania was much richer than that of Hungary's, and involved such instruments or combinations as one or two violins, guitar, peasant flute, or bagpipes. ${ }^{167}$ The composer expresses his admiration:

It was only curiosity that made me investigate the Romanian folklore at the beginning...I could not turn back anymore. At first I was lured deeper into that country by the incomparable beauty of the songs. It was like picking flowers on a wild field, so pure and abundant was the song harvest there. ${ }^{168}$

Bartók precisely identifies the origin of each dance in the score. By transcribing the folk songs, he naturally had to give up the original timbre, but chose the register that would invoke it best. The complex rhythms and rich decoration of original tunes were also lost in the process of arrangement. However, the left hand he provided as accompaniment has a far greater harmonic

\footnotetext{
${ }^{166}$ Gillies, 147.

${ }^{167}$ Ibid, 147.

${ }^{168}$ Agatha Fassett. The Naked Face of Genius: Béla Bartók’s American Years. (Boston Cambridge Press, 1958), 328.
} 
richness than found in the original. The choice of tempo was similar, but Bartók hardly ever preserved the tempos of original tunes; instead, he added more speed to fast dances and decreased speed in the slow ones, therefore giving an individual character to each piece. He took advantage of the variety of tempos in arranging these pieces into a series of six movements, creating a kind of suite. ${ }^{169}$

All have $2 / 4$ meter except for the fourth piece, which is in $3 / 4$, and the fifth which uses both meters. All dances are in binary form with a strict rhythmic tempo in Giusto style. Bartók transcribed these dances for orchestra in 1922.

1. "Joc cu Bâta” (meaning "dance with sticks"), Allegro Moderato. The modes used are A Dorian and Aeolian. Bartók first heard this melody played by two Gypsy violinists in Mezöszabad, Transylvania. Here the left hand has a strict rhythm, while the right hand plays a syncopated folk tune. ${ }^{170}$ Looking closely at the melody, one can notice that the dance has characteristics of Old Style Hungarian folk song: the melody starts with an ascending line and moves in stepwise motion, avoiding big jumps. The biggest interval in the main theme is a third.

\footnotetext{
${ }^{169}$ Gillies, 148

${ }^{170}$ Nissman, 105.
} 

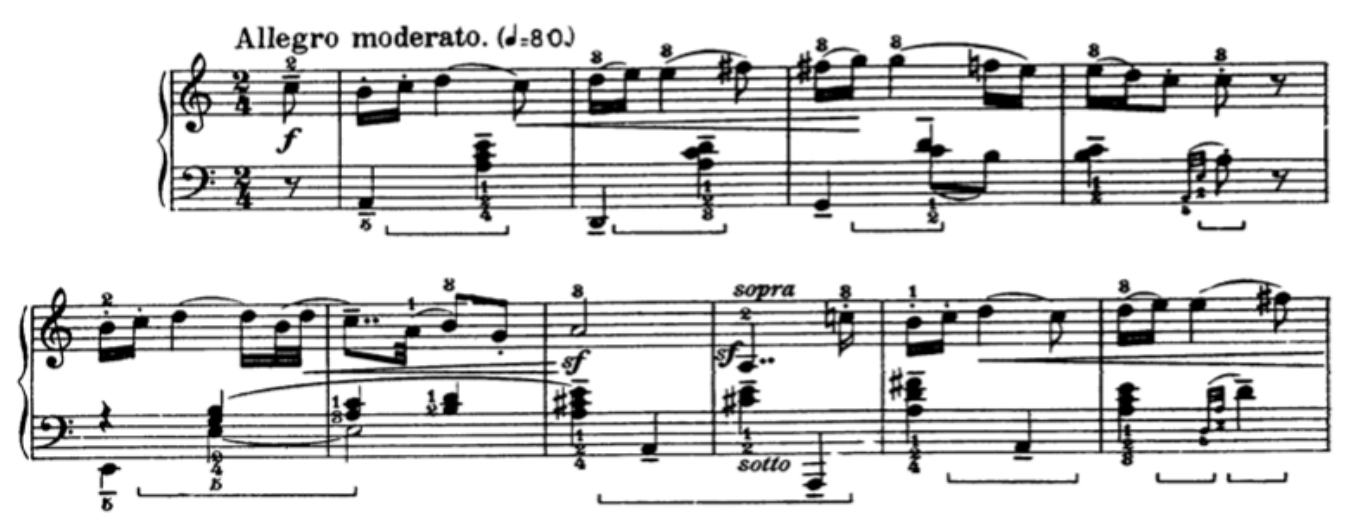

Figure 32. B. Bartók, “Joc cu Bâta” from Romanian Dances, mm. 1-10

2. "Brâul" (meaning waistband dance or sash dance), Allegro. A Brâul was performed by couples with a cloth belt held between them. The mode used is D Dorian. The composer heard the melody from a 30-year-old flute player in a Romanian village, Egres. In the orchestral version, Bartók gave the main melody to the clarinet. This melody also has a descending line and uses stepwise motion. ${ }^{172}$
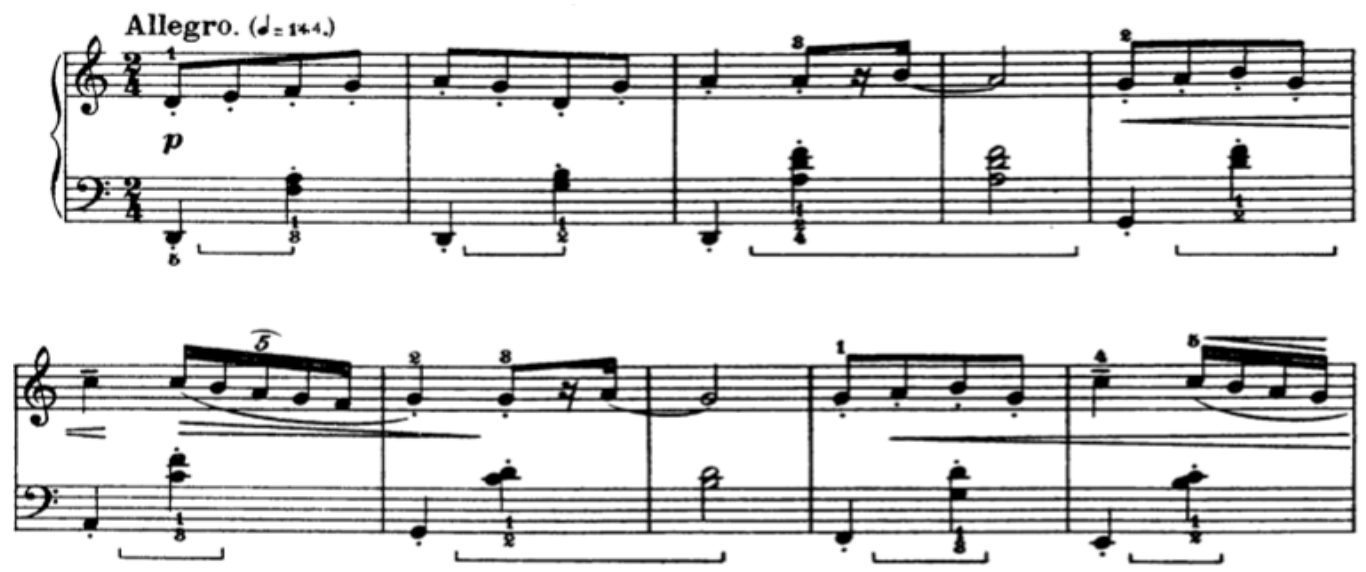

Figure 33. B. Bartók, "Brâul” from Romanian Dances, mm. 1-10

\footnotetext{
171 "Main Page," IMSLP/Petrucci Music Library: Free Public Domain Sheet Music, accessed September 12, 2017, http://imslp.org/.

${ }^{172}$ Nissman, 105.

173 "Main Page," IMSLP/Petrucci Music Library: Free Public Domain Sheet Music, accessed September 12, 2017, http://imslp.org/.
} 
3. "Pe Loc" (meaning "in one spot"), Andante. Pe Loc is a pair dance in which the dancers move in very small steps. The rich, exotic sound is created by the B Aeolian and Gypsy scales with the characteristic augmented second, D-E sharp. The melody is also from Egres but it is much darker than the previous Allegro, and recreates the Middle Eastern instruments, such as the flute. Zoltán Székely, who transcribed this set for violin and piano, added harmonics for the violin, which imitates very well the sound of the furulya, shepherd's flute. This slow, steady rhythmic dance was accompanied by bagpipers. ${ }^{174}$ Here the bagpipe accompaniment is almost identical in sound to that of the Sonatina's first movement.
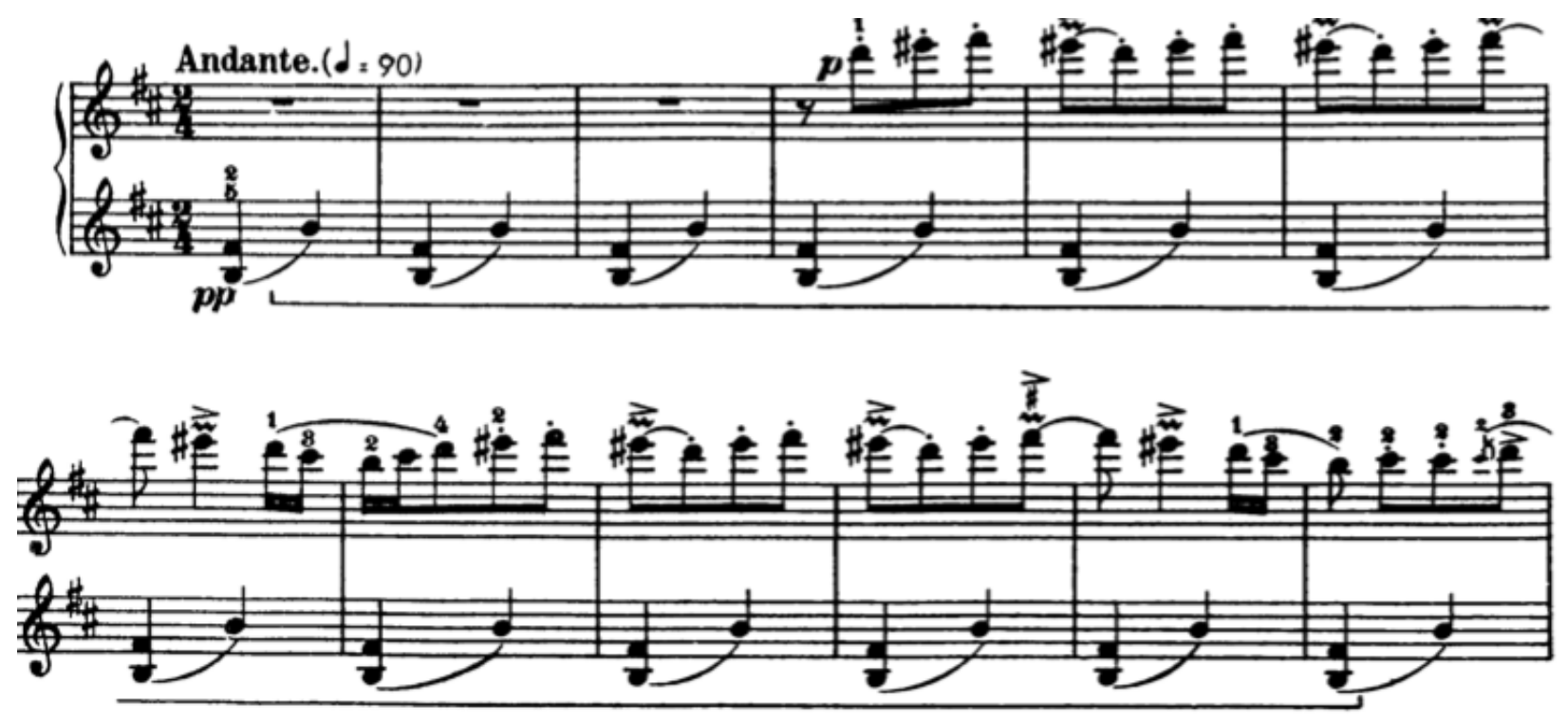

Figure 34. B. Bartók, "Pe Loc" from Romanian Dances, 1-12

\footnotetext{
${ }^{174}$ Nissman, 105.

175 "Main Page," IMSLP/Petrucci Music Library: Free Public Domain Sheet Music, accessed September 12, 2017, http://imslp.org/.
} 
4. "Buciumeana" ("hornpipe dance"), Moderato. This is an expressive dance in 3/4 meter.

Bartók first heard the melody played by a Gypsy violinist in a Romanian village called Belényes.

It is built on A Mixolydian, with $\mathrm{C \#}$ and $\mathrm{Bb}$ adding an exotic sound to the piece. The segment ends on the dominant, an A-major chord which serves as a transition to the next part. Here the folk melody is the most important part of the work; it is the "jewel" of the work and the added accompaniment may be considered as the "mounting of the jewel."
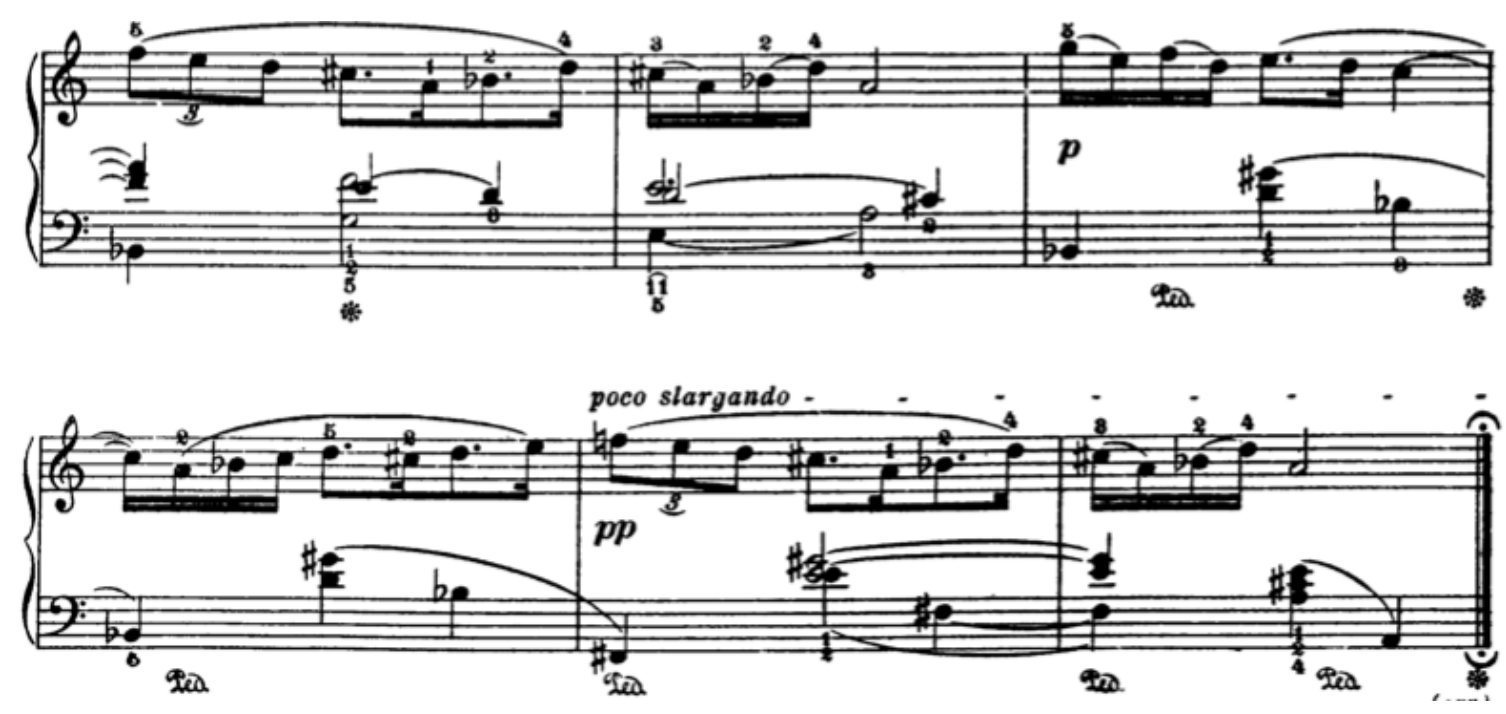

Figure 35. B. Bartók, "Buciumeana" from Romanian Dances, mm. 13-18

5. "Poarca Româneasca" (meaning "Romanian polka"), Allegro. This is a fast children's dance with complex rhythm. The melody is in groups of three, three, and two beats, using the D Lydian scale. Bartók heard the melody from a Gypsy violinist in Belényes, Romania, and dedicated the

\footnotetext{
${ }^{176}$ Béla Bartók and Benjamin Suchoff, 351.

177 "Main Page," IMSLP/Petrucci Music Library: Free Public Domain Sheet Music, accessed September 12, 2017, http://imslp.org/.
} 
piece to his friend, Ioan Busita, who was also from Belényes. ${ }^{178}$ The bagpipe accompaniment from the third dance returns:
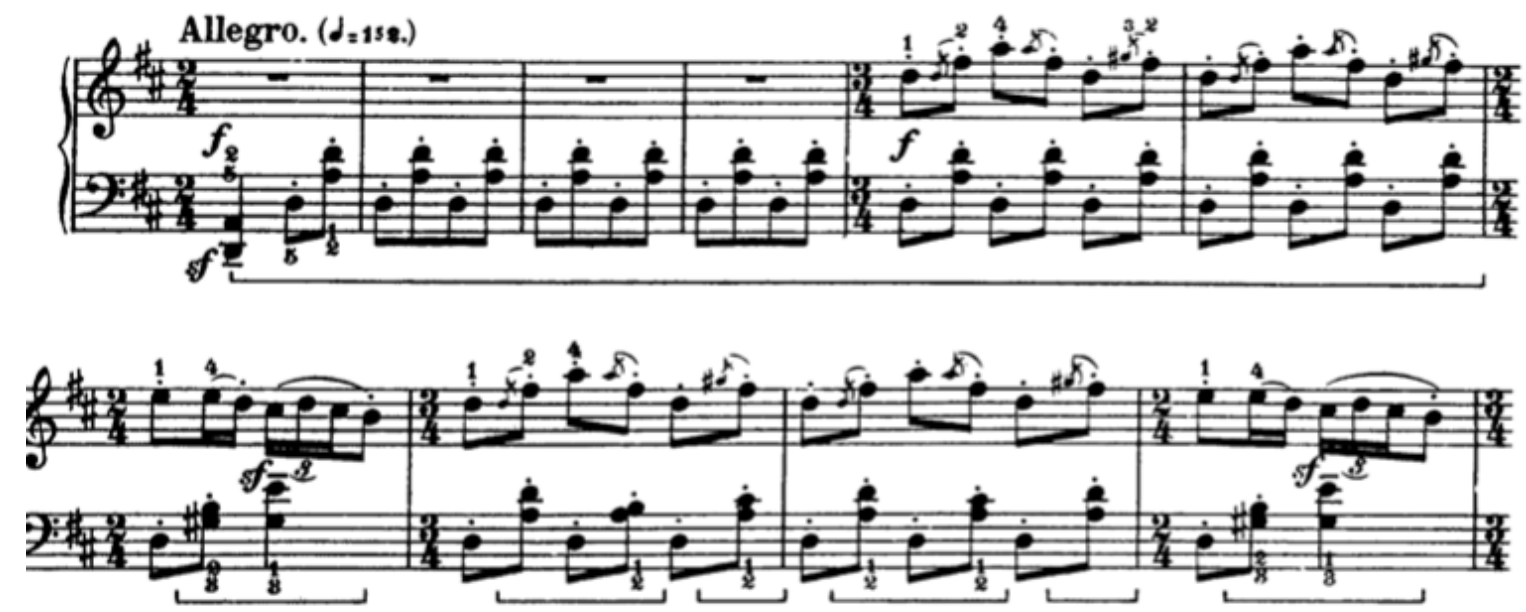

Figure 36. B. Bartók, "Poarca Româneasca” from Romanian Dances, mm. 1-10

6. "Măruntel" (meaning "small”), Allegro. The concluding piece includes two quick dances from Belényes and Neagra; these dances feature very small steps and quick movements. They are composed in the typical style of Bartók's folk-dance finales, quick and entertaining. ${ }^{180}$ The first part uses A Lydian and Mixolydian scales, while the second part is in A Dorian. Just as we saw in the ending of Sonatina, the short Coda is a mix of the two melodies and the repeated motives make the ending more convincing with the piu forte and sforzando.

\footnotetext{
${ }^{178}$ Nissman, 105.

179 "Main Page," IMSLP/Petrucci Music Library: Free Public Domain Sheet Music, accessed September 12, 2017, http://imslp.org/.

${ }^{180}$ Gillies, 148.
} 

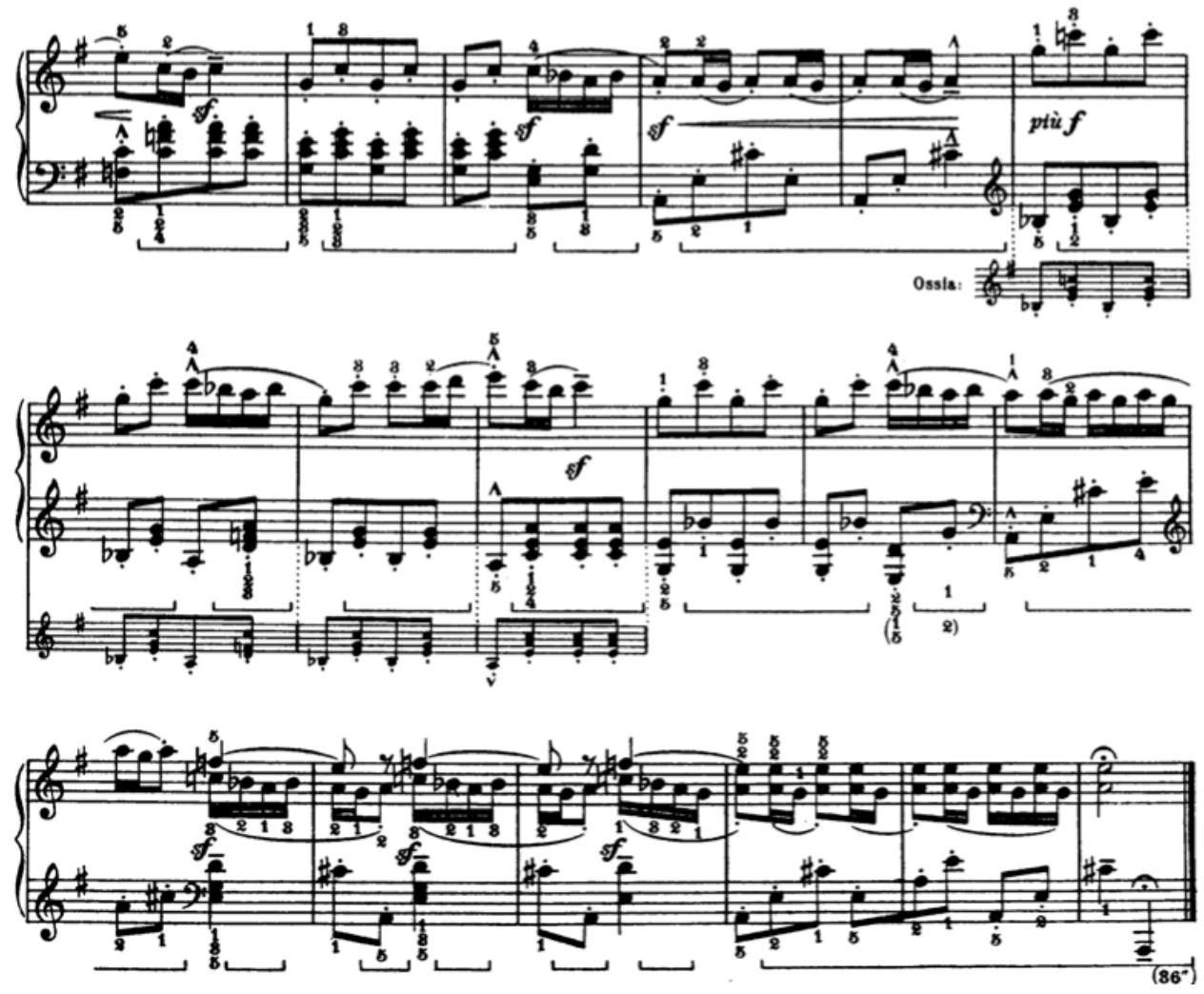

Figure 37. B. Bartók, “Măruntel” from Romanian Dances, mm. 45-62 ${ }^{181}$

\section{Three Hungarian Folk Songs from Csik (1907)}

In 1907, Bartók was appointed chair of the piano faculty at the Academy of Music in

Budapest. This period was marked by his interest in compositions for piano that expressed his main focuses:

1. His desire to forge a new individualistic musical language.

2. The need for a repertoire of pedagogical music to fulfill his teaching duties. 181 "Main Page," IMSLP/Petrucci Music Library: Free Public Domain Sheet Music, accessed September
12, 2017, http://imslp.org/. 
His important discoveries as an ethnomusicologist helped to inspire keyboard creations and it was through piano music that the spirit of folk music was assimilated into his art. ${ }^{182}$

His first arrangements for piano were Három Csík Megyei Népdal ("Three Hungarian Folk Songs from the Csík District"). These simple settings were composed along similar lines to the Twenty Hungarian Folk Songs. All three parts are uniquely based on original material collected by Bartók, functioning as a "jewel." The composer transcribed these pieces exactly as he heard them from the peasants singing and playing the flute, and all the ornamental embellishments possibly originate from them. ${ }^{183}$ Csík is a district in Székelyfold, a part of Transylvania. The transcriptions suggest freely improvised qualities, yet the folk tunes must still be played simply.

The first two folk melodies are written in parlando-rubato style, while the last melody is in tempo giusto with dance rhythm.

\section{1. "The Peacock"}

Röpülj Páva Röpülj ("Fly Peacock Fly”) is the tune which is often referred as Bartók’s peacock melody because of its resemblance to the emblematic Hungarian Old Style folk song that Kodály found and arranged in several of his later compositions (including the Peacock Variations for orchestra):

\footnotetext{
182 Nissman, 36.

${ }^{183}$ Ibid, 52.
} 


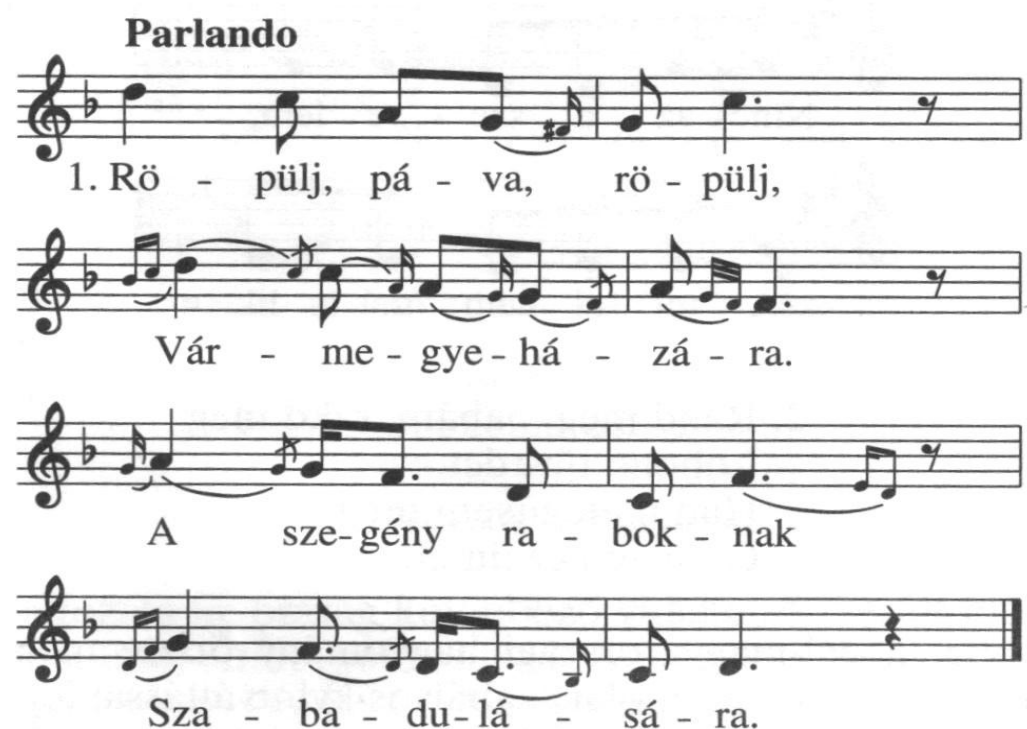

Figure 38. Röpülj Páva Röpülj ('Fly Peacock Fly"), folk song collected by Kodály ${ }^{184}$

However, studies on Bartók have pointed out that he did not know the peacock melody until $1935 . .^{185}$

Bartók collected Romlott Testem, another Old Style parlando song with a similar melodic line, during his first collecting trip in Transylvania among the Székely people in the summer of 1907. He heard the theme played by a 50-year-old man on tilinko, a flute-like instrument. ${ }^{186}$

\footnotetext{
${ }^{184}$ Www.nagykunreformatus.hu/content_g/.../regi_stilus.html. 185 "„ROMLOTT TESTËM” ÉS A „PÁVA”-DALLAM - mzzt.hu," accessed April 5, 2017, http://www.bing.com/cr?IG=D5E65175B53C44C8B5F87A833C0CC8B9\&CID=1011AE4EB31E685B2A7AA415 B289690F\&rd=1\&h=YdAeCUjSxf20VCrlwAJhvJoXgLdd8s7W2 Oy1QVZOX4\&v=1\&r=http\%3a\%2f\%2fmzzt.h u $\% 2$ fpdfs $\% 2 \mathrm{fmz} \% 252020102$ 203-213 Somfai.pdf\&p=DevEx,5060. 213. Translated by Helga Scheibert ${ }^{186}$ Ibid.
} 


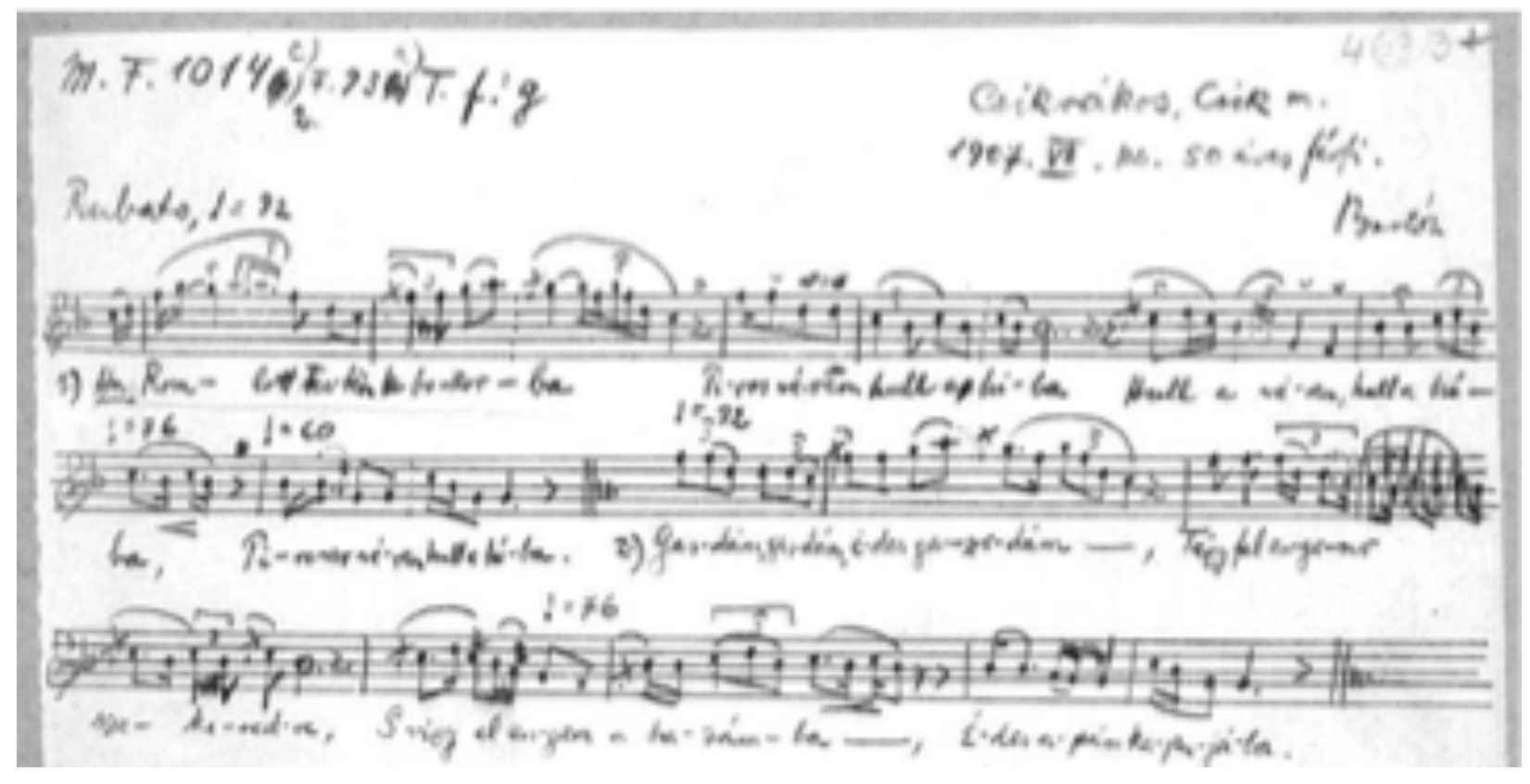

Figure 39. Bartók's sketch of Romlott Testem from Csíkrakos $1907^{187}$

187 "„ROMLOTT TESTËM” ÉS A „PÁVA”-DALLAM - mzzt.hu," ,accessed April 5, 2017, http://www.bing.com/cr?IG=D5E65175B53C44C8B5F87A833C0CC8B9\&CID=1011AE4EB31E685B2 A7AA415B289690F\&rd=1\&h=YdAeCUjSxf20VCrlwAJhvJoXgLdd8s7W2 Oy1QVZOX4\&v=1\&r=http $\% 3 \mathrm{a} \% 2 \mathrm{f} \% 2 \mathrm{fmzzt}$. hu\%2fpdfs\%2fmz\%25202010_2 203-213 Somfai.pdf\&p=DevEx,5060. 213.

Translated by Helga Scheibert 
This theme also appears in his First String Quartet. See Figure 40.

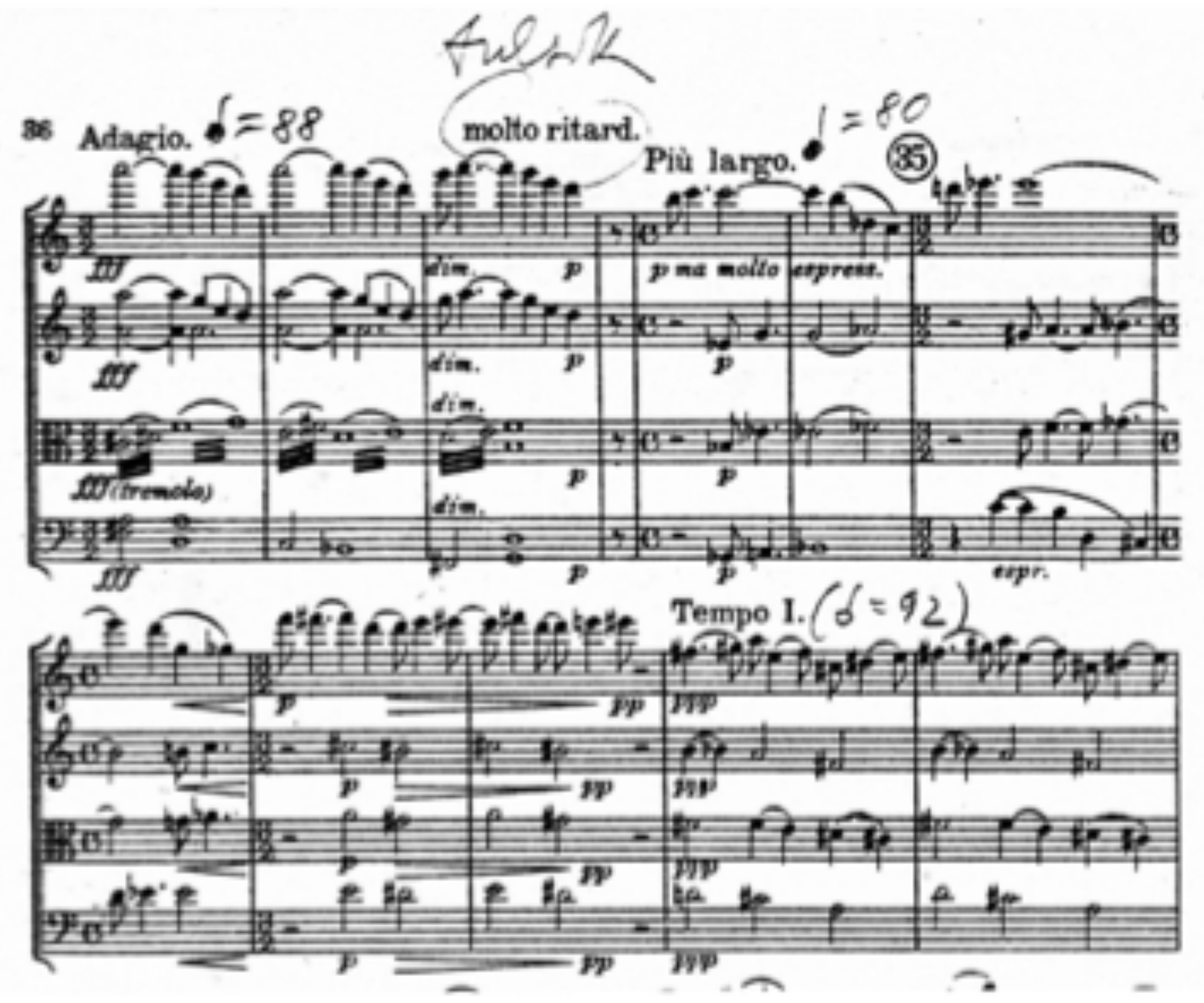

\section{Figure 40. B. Bartók First String Quartet $^{188}$}

In his essay "Romlott Testem and the Peacock Melody," László Somfai demonstrates, on basis of data taken from Bartók's field notations in Transylvania, as well as his letters to Stefi Geyer, that Romlott Testem was not among the tunes he selected for composition (arrangement)

188 "„ROMLOTT TESTËM” ÉS A „PÁVA”-DALLAM - mzzt.hu," ,accessed April 5, 2017, http://www.bing.com/cr?IG=D5E65175B53C44C8B5F87A833C0CC8B9\&CID=1011AE4EB31E685B2 A7AA415B289690F\&rd=1\&h=YdAeCUjSxf20VCrlwAJhvJoXgLdd8s7W2 Oy1QVZOX4\&v=1\&r=http $\% 3 \mathrm{a} \% 2 \mathrm{f} \% 2 \mathrm{fmzzt} . \mathrm{hu} \% 2 \mathrm{fpdfs} \% 2 \mathrm{fmz} \% 252020102 \quad 203-213$ Somfai.pdf\&p=DevEx,5060. 213.

Translated by Helga Scheibert 
in 1907. Somfai also suggests that Bartók's melody in the First Quartet is not a quotation but rather an abstraction inspired by the newly discovered pentatonic scale of the old Székely folk songs. ${ }^{189}$ I believe that Bartók used another abstraction of Romlott Testem in the Three Hungarian Folk Songs from Csik. Comparing the two examples below, we observe the melodic, rhythmic difference and transformation. See Figures 41 and 42 below.

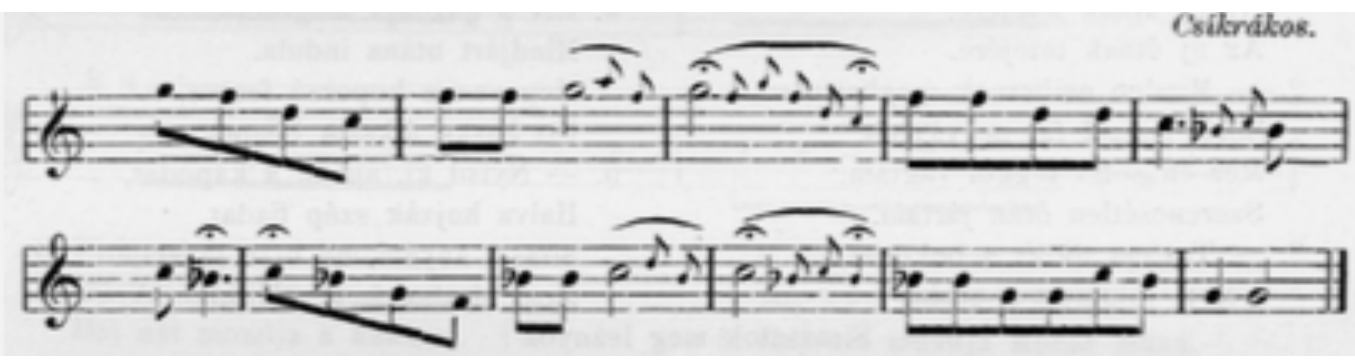

Figure 41. B. Bartók, Romlott Testem ${ }^{190}$
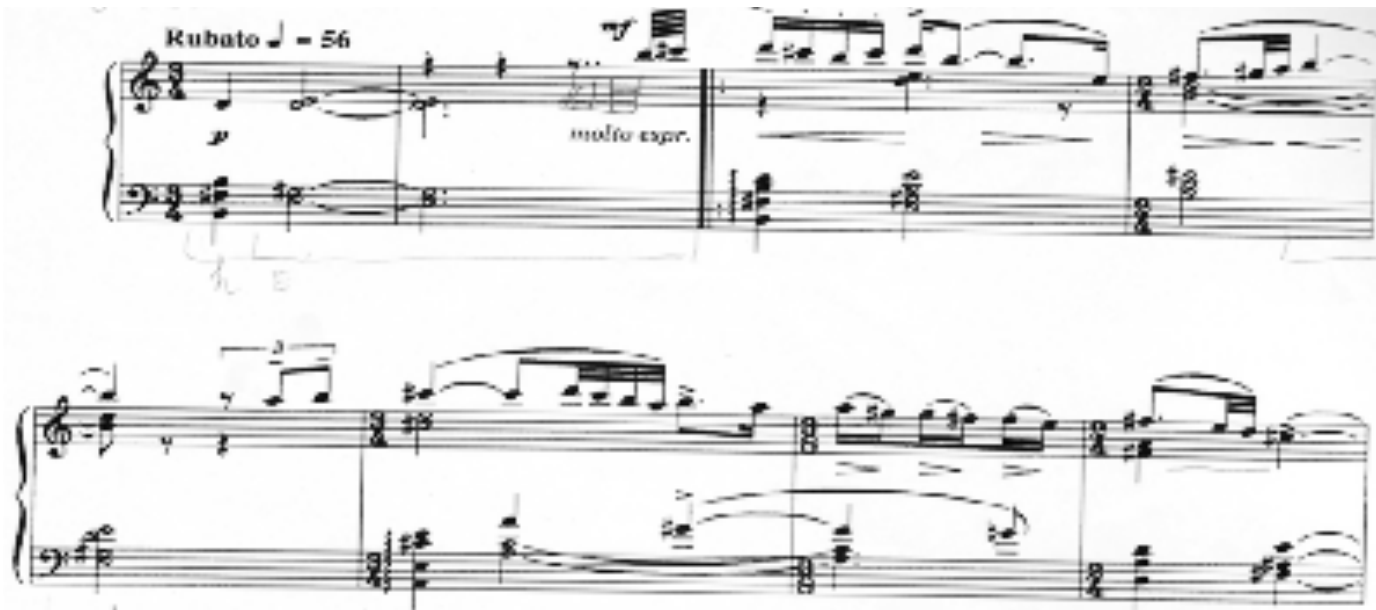

Figure 42. B. Bartók, "The Peacock" from Three Hungarian Folk Songs, mm. 1-8

\footnotetext{
189 „ROMLOTT TESTËM” ÉS A „PÁVA”-DALLAM - mzzt.hu," accessed April 5, 2017, http://www.bing.com/cr?IG=D5E65175B53C44C8B5F87A833C0CC8B9\&CID=1011AE4EB31E685B2A7AA41 5B289690F\&rd=1\&h=YdAeCUjSxf20VCrlwAJhvJoXgLdd8s7W2 Oy1QVZOX4\&v=1\&r=http $\% 3 \mathrm{a} \% 2 \mathrm{f} \% 2 \mathrm{fmzz}$ t.hu $\% 2$ fpdfs $\% 2 \mathrm{fmz} \% 252020102$ 203-213 Somfai.pdf\&p=DevEx,5060.1. Translated by Helga Scheibert ${ }^{190}$ Ibid.

191 "Main Page," IMSLP/Petrucci Music Library: Free Public Domain Sheet Music, accessed September 12, 2017, http://imslp.org/.
} 
The sweetly singing tune is played mostly in B Dorian mode, lacking the major seventh degree; consequently the dominant/tonic function is missing.
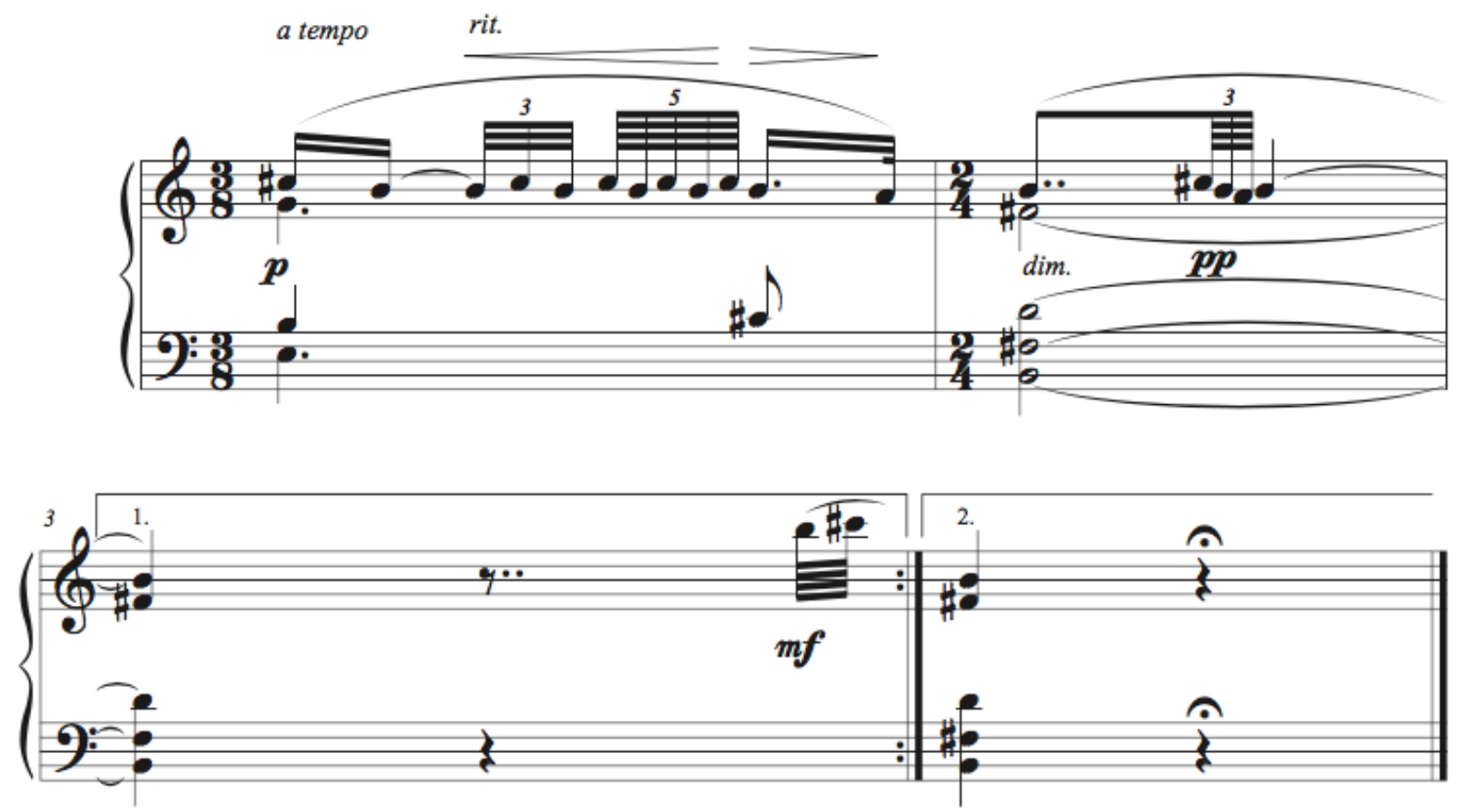

Figure 43. B. Bartók, “The Peacock" from Three Hungarian Folk Songs, mm. 14-16"192

The accompaniment is quite limited, giving more importance to the improvisatory main melody. Marked Rubato, it has a charming character and the overall mood is one of pastoral tranquility.

The tune is based on an Old Style folk song (Romlott Testem). It features tempo rubato, rich ornamentation, the non-rounded quaternary $(\mathrm{ABCD})$ section structure, and the eight-syllable text line in each.

192 "Main Page," IMSLP/Petrucci Music Library: Free Public Domain Sheet Music, accessed September 12, 2017, http://imslp.org/. 
The peacock is a symbol of freedom in Hungary. This symbol is a favorite among Hungarians and it is used quite often. For me personally it also suggests a metaphor, in that perhaps Bartók wants to express how timbrally rich this Old Style melody is, as colorful as the feathers of a peacock.

The last two lines should be interpreted very freely, as Bartók marks in the score. The performance marking here constantly switches between poco ritardando and a tempo.
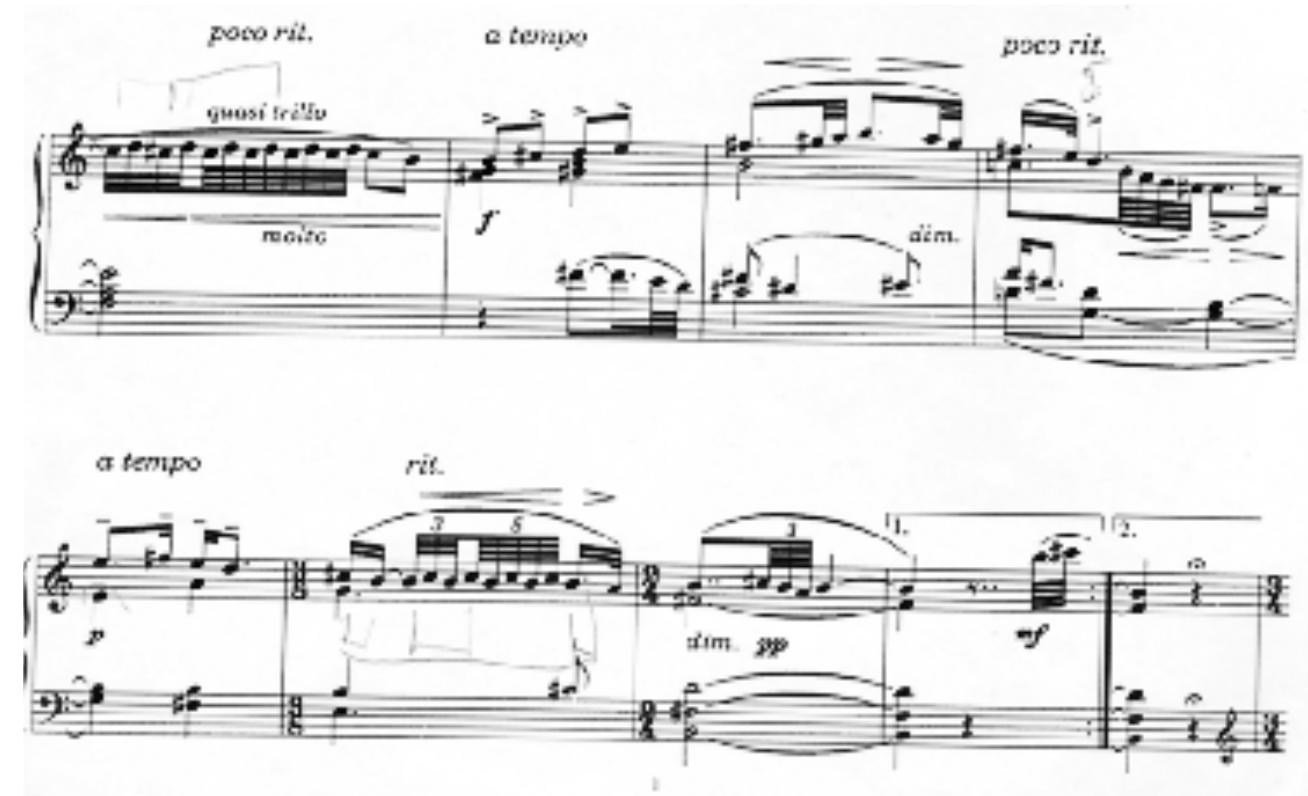

Figure 44. B. Bartók, “The Peacock” from Three Hungarian Folk Songs, mm. 9-16

2. "At the Jánoshida fairground"

Jánoshida is the name of a small city in Solnok County, Hungary. There is a dilemma about Bartók's title Three Hungarian Folk Songs from Csík, since Csík is a county in Transylvania, while Jánoshida is located in Hungary. Bartók states that he collected these songs

193 "Main Page," IMSLP/Petrucci Music Library: Free Public Domain Sheet Music, accessed September 12, 2017, http://imslp.org/. 
from Transylvania and not Hungary. Therefore there is reason to wonder why he named it "At the Jánoshida fairground."

As we look further into the original melody source, we discover additional issues.

This is the original Hungarian folk melody with the same title :

\section{JÁNOSHÍdI VÁSÁRTÉREN, ICA, TE}

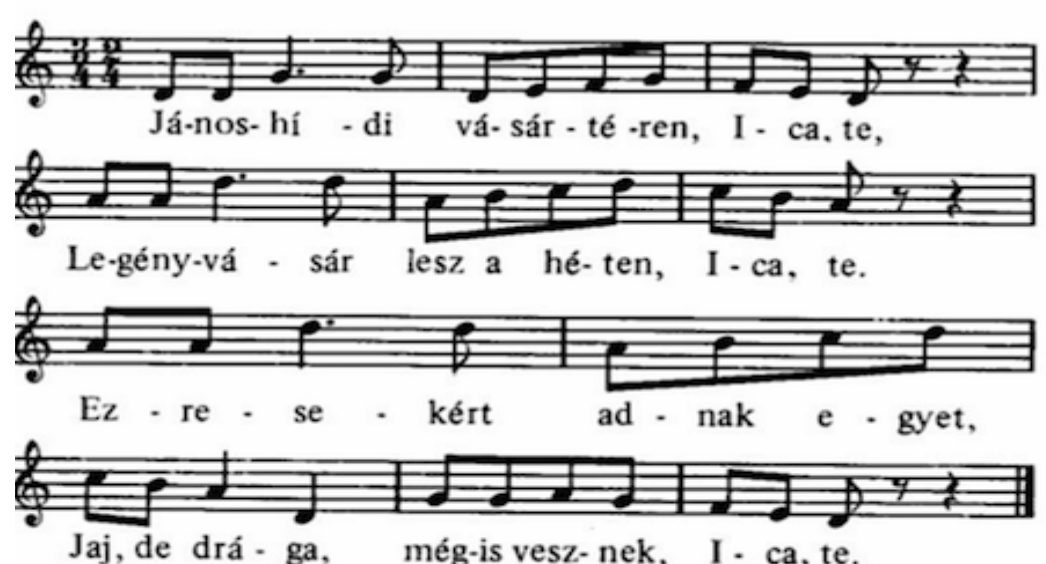

Figure 45. Jánoshídi Vásártéren ("At the Jánoshida Fairground")

${ }^{194}$ A dalok oldala, accessed October 15, 2017,

http://mek.oszk.hu/05700/05702/html/a_dalok.htm. 
The example below is from Three Hungarian Folk Songs from Csik

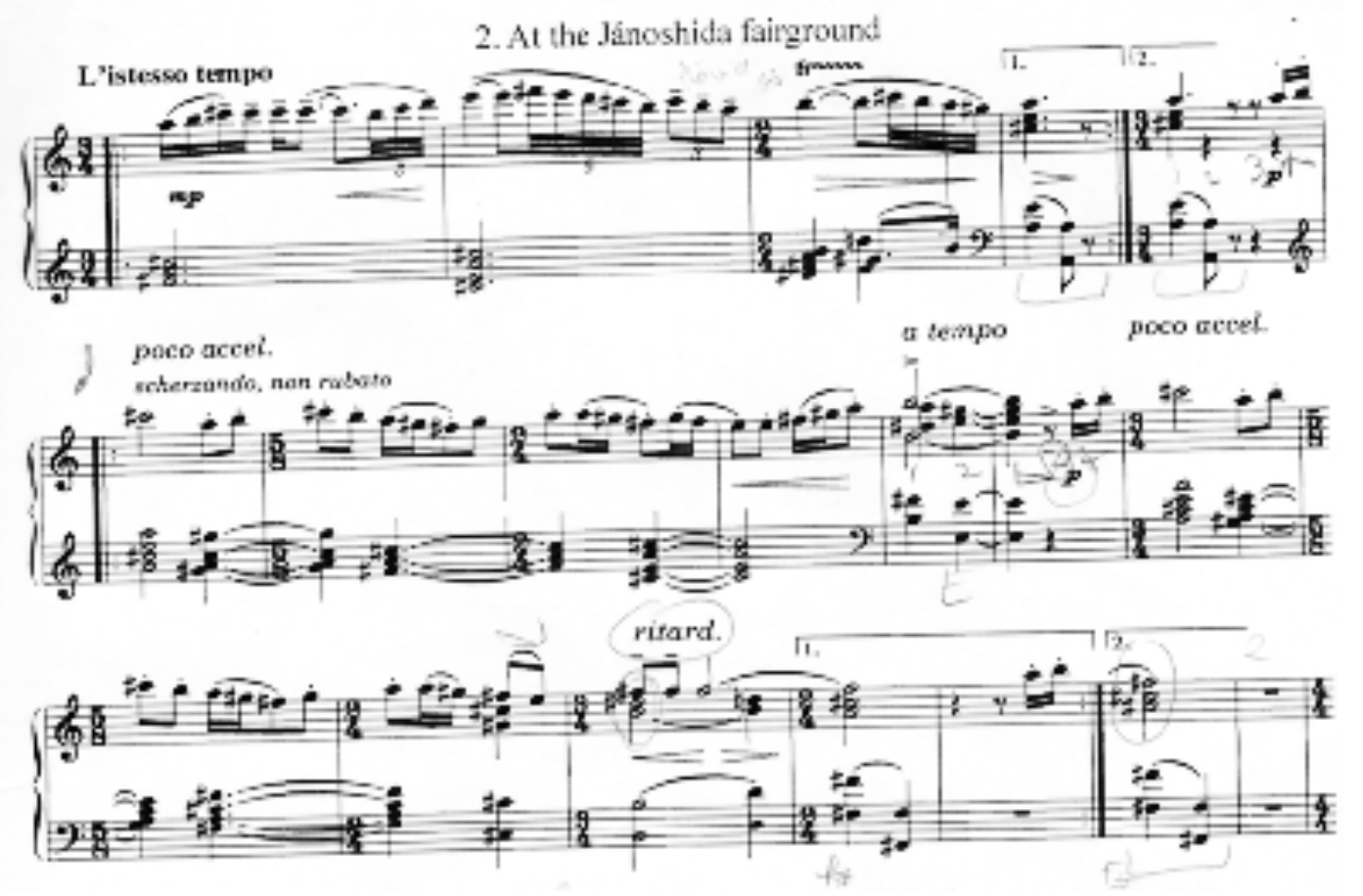

Figure 46. B. Bartók “At the Jánoshida Fairground” from Three Hungarian Folk Songs, mm. 1-16 195 $^{195}$

Comparing the two melodies, there are melodic and rhythmic differences. It is conceivable that Bartók took the melody from another folk song but used this title. It is also possible that he just wanted to keep a few elements from the original version, such as the step-by-step ascending and descending melody lines, dotted rhythms, and meter changes. Bartók's version is so heavily ornamented that is hard to find the original song within it.

\footnotetext{
195 "Main Page," IMSLP/Petrucci Music Library: Free Public Domain Sheet Music, accessed September 12, 2017, http://imslp.org/.
} 
By comparison with the original folk song, Bartók significantly emphasises some of the notes by multiple repetitions or by adding ornaments. The original version also has many repeated notes.

Marked L'istesso tempo, Bartók's version conveys the same mood and character as “The Peacock," although perhaps it is even slower because of the hesitations at the ends of phrases 3. "White Lily"

Marked Poco vivo, the last piece is in contrast with the two peaceful previous works, having a more energetic and virtuosic manner. The repeated notes and ornaments are heavily used, just as in the previous two movements. The left hand has rolled chords which evoke the sound of the cimbalom. See Figure 47.

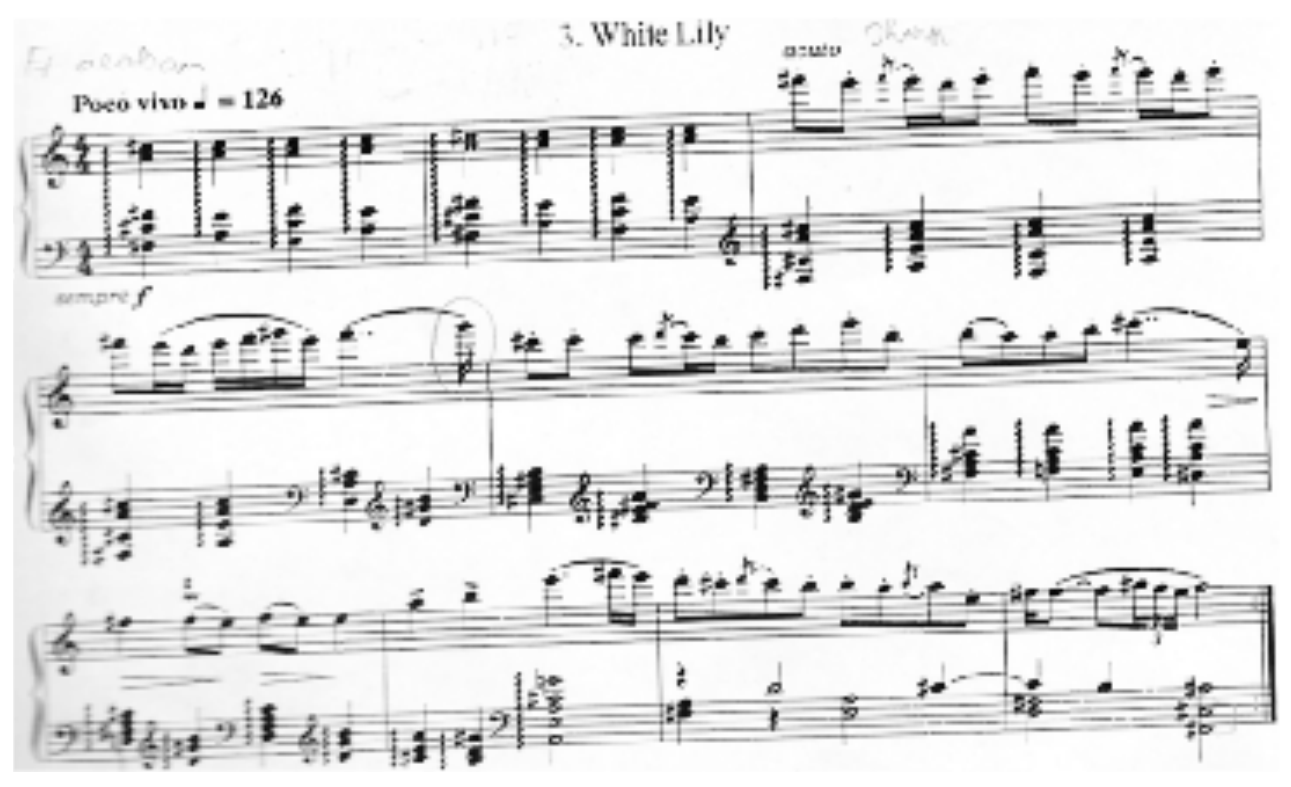

Figure 47. B. Bartók "White Lily" from Three Hungarian Folk Songs, mm. 1-9196 196 "Main Page," IMSLP/Petrucci Music Library: Free Public Domain Sheet Music, accessed September
12, 2017, http://imslp.org/. 
The white lily is often given symbolic meaning in Hungary, with connotations of "virgin and immaculate." The original melody here is actually titled differently, Ha Kimegyek Arra a Magas Tetöre ("If I go up to the high mountains"). ${ }^{197}$ A characteristic feature of this song is the many repeated notes.

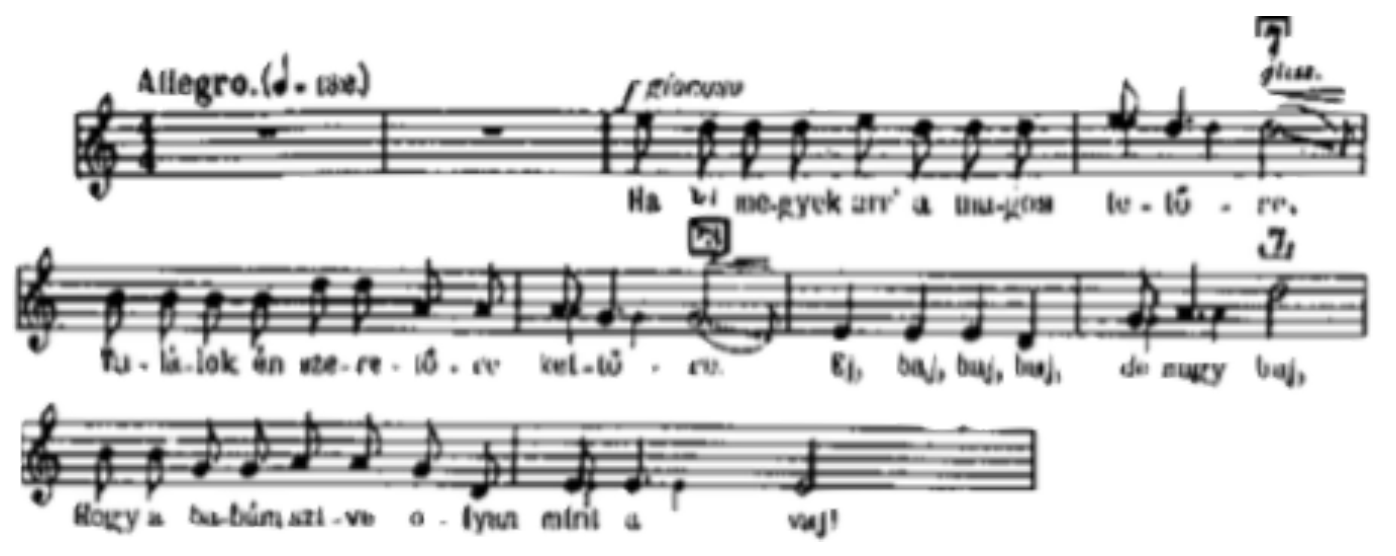

Figure 48. B. Bartók Ha Kimegyek Arra a Magas Tetöre ("If I Go Up to the High

\section{Mountains") ${ }^{198}$}

This is in the E-pentatonic scale (E-G--A-B-D) with four phrases.

The form is as follows:
A Ha kimegyek arr' a magos tetőre
B Találok én szeretőre kettőre.
C Ej, baj, baj, baj, de nagy baj,
D Hogy a babám szive olyan mint a vaj!

("If I go up to the high mountains

I will find a sweetheart, maybe two. Trouble, trouble, what a lot of trouble, That my darling's heart is as soft as butter.')

\footnotetext{
${ }^{197}$ Yu-Yong Lee, 55.

${ }^{198}$ Ibid, 58.
} 
This appears to be an Old Style folk song with non-rounded form: ABCD. The syllables are isometric $(11,11,7,11)$. The stepwise motion is another reminder of the Old Style.

Interestingly the isometry is inconsistent because of the slight variant in the third line. Perhaps this “defect" captured Bartok's attention.

The text is about love. It will not matter if the singer finds himself two new lovers at once; even then he won't be happy, because he is also longing for his old girlfriend. The mood of the text is frivolous and free, but also unhappy and longing.

Bartók used the same melody in Eight Hungarian Folk Songs for Voice and Piano, No. 5. See Figure 48.

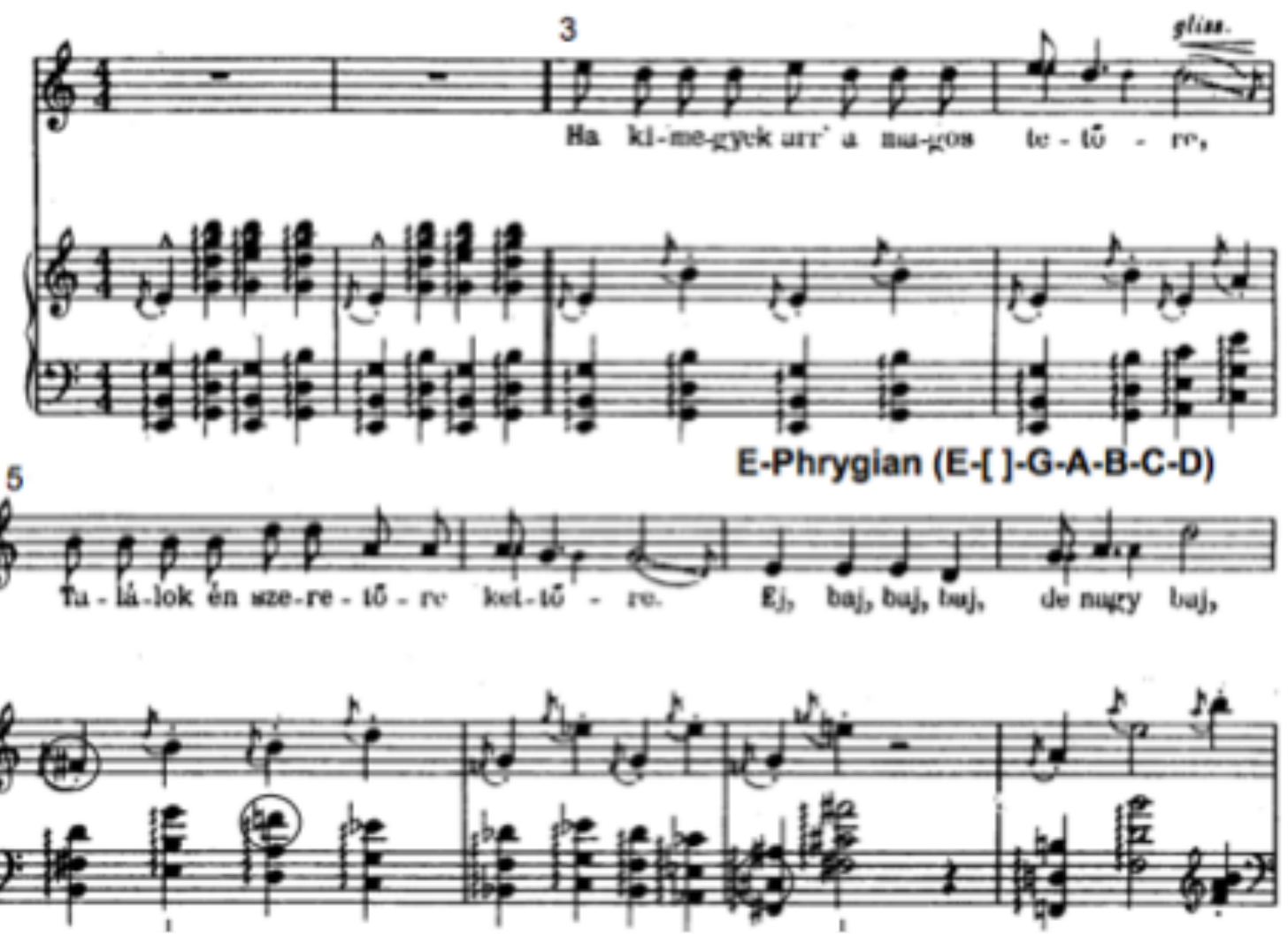

Figure 49. B. Bartók, Eight Hungarian Folk Songs for Voice and Piano, No. 5 mm. 1-8 ${ }^{199}$

${ }^{199}$ Yu-Yong Lee, 58. 
As seen above, the original version is in E Pentatonic (E-G-A-B-D), the voice and piano setting is in E Phrygian, and the piano-solo version uses F\# Aeolian (F\#-G\#-A-B-C\#-D-E). All three examples are highly ornamented and show the characteristics of Old Style folk song.

\section{Third Piano Concerto (1945)}

I chose to discuss this piece, written by Bartók during his last year, because knowing it helped me to appreciate Bartók’s music even more. Some of this concerto's uniqueness is created by the melodies, rhythms, and orchestration. The melodic and rhythmic features bear resemblances to those of Stravinsky, while the derivation of melody and harmony recalls

Debussy, Scriabin and Schoenberg, as well as Stravinsky. ${ }^{200}$ These are all composers whose styles I enjoy and highly admire.

This piece moves beyond traditional tonality; yet the influence of folk music is evident. Being a native of Transylvania only increases my appreciation for the Concerto and hearing it instills a sense of nostalgia. Furthermore, this piece suggests to me a world full of new life, energy, and beauty. In a single word, I would describe this music as "sublime."

The fact that Bartók created this work on his deathbed probably adds even more to my admiration. How is it even possible to create such a touching second movement or a third movement so full of life and energy while you know that you are dying?

Among the many difficulties in Europe during the Second World War was the deep influence of Nazi Germany on Hungary’s government and culture. Bartók, together with his wife Ditta, migrated to America and settled in New York City in October of 1940. The move was

${ }^{200}$ Gillies, 540. 
difficult; a man of 59 years with a profound love for his homeland was not able to bear such a transplant easily. ${ }^{201}$

During his American years he supported himself primarily through ethnographical work at Columbia University and concert tours as a pianist or duo-pianist with his wife. He wasn't known as a composer in America, and in his early years in the New World he didn't compose much. The reasons are unclear for his lack of writing, but it may have been depression, a lack of inspiration, or even homesickness. From 1940-1945, Bartók composed only four works: Concerto for Orchestra (1943), Sonata for Solo Violin (1944), Piano Concerto No. 3 (1945), and Viola Concerto (1945). ${ }^{202}$

He was diagnosed with leukemia in April, 1942, and the disease reached a critical stage in February, 1943. Bartók died in 1945, at the age of 64.

The Piano Concerto No. 3 and Viola Concerto were written simultaneously during a period of declining health and both were left unfinished at the composer's death. All four works from these last years share certain late-style characteristics: retrospection, nostalgia, and simplification. ${ }^{203}$

These traits are especially obvious in the Third Piano Concerto, as Straus states:

The serenity of the Third Piano Concerto is remarkable among Bartók's larger works. His progressive trend toward both structural and tonal lucidity is exemplified through this Concerto. In both texture and orchestration there is extreme clarity, sometimes to the point of tenuousness. If the Third Piano Concerto is to be considered weaker than the first two, it must be because of the extreme refinement of its idiom. Both the harmonic and the melodic elements of the Concerto represent a distillation of Bartók's maturest style: the tendency toward a more strongly affirmed tonality, lucid texture, plastic rhythms, is here

\footnotetext{
${ }^{201}$ Joseph Nathan Straus, Extraordinary Measures: Disability in Music (New York: Oxford University Press, 2011), 95.

202 Straus, 95.

${ }^{203}$ Straus, 96.
} 
intensified. $^{204}$

1945 was the year when Bartók was in the terminal stage of his illness, and he did not finish the last 17 bars of the Concerto. Fortunately, Tibor Serly, one of his most outstanding students, finished the work after Bartók's death. ${ }^{205}$

This concerto is very different compared to the others because Bartók returned here to Neoclassical style, making use of tonal melodies with much easier rhythmic patterns. The fact that the dark colors and the "barbaro" rhythms are missing from this concerto perhaps indicates that at the end of his life Bartók was giving up the rougher dissonances from his avant-garde past, replacing them with more harmony and balance. He did not strive for the "completeness" which characterized his earlier concertos. Perhaps this composition consciously illustrates only the brighter, sunnier and more relaxed portion of Bartók's artistic world. ${ }^{206}$

On the performance of the concerto Barbara Nissman offers wise advice:

A truly successful performance of this final concerto is rare. Most pianists want to make more out of the work than is necessary and tend to treat it too seriously. They fail to capture its playful, unpretentious qualities and try to substitute inflated virtuosity for Bartók's infectious simplicity.

Bartók already experienced complexity in all musical forms in his twenties and thirties, but it looks like he had special connection to folk music and was primarily attracted by its simplicity. Always, his objective remained to search and to arrive at the musical "truth." To reveal the essence of an idea meant exposing its innate simplicity.

Bartók wrote this concerto as a surprise $42^{\text {nd }}$-birthday present for his pianist wife, Ditta Pasztory. In the past year he had become convinced that Ditta had real difficulties with the piano part of the Second Concerto, as her strength was not sufficient for the dense octave and chordal

\footnotetext{
${ }^{204}$ As cited in Straus, 96.

${ }^{205}$ Gillies, 539 .

${ }^{206}$ Ibid, 540.

${ }^{207}$ Nissman, 283.
} 
passages. Perhaps this was reason enough to write another concerto, still of virtuoso character but technically easier than the second. ${ }^{208}$

\section{First Movement (Allegretto)}

The fundamental key of the concerto, E Major, is not uncommonly used among Bartók's works. But in contrast to his earlier E-based works, (for example, the First Piano Concerto and the Sonata for Piano) this work has strong connections with nineteenth-century music in that key, such as Mendelssohn's A Midsummer Night's Dream and the Lisztian Waldesrauschen. ${ }^{209}$

This movement is in sonata form and has a very gentle theme exposition in double octaves with a chordal orchestral accompaniment. The main theme is based on a Hungarian folk song, which is introduced by the piano in the second bar. The use of a double-dotted rhythm recalls the $19^{\text {th }}$-century Hungarian verbunkos dance. The verbunkos had come a long way in Bartók's work: as a youth he used it often, but around 1904 he turned away from it. In mid-1910 he recalled the verbunkos in his ballet The Wooden Prince, but cast it in a negative role to characterize the cold and rigid princess. In the Third Piano Concerto, the verbunkos rhythm appears thematically as a heavenly phenomenon over the rustling string background. ${ }^{210}$

\footnotetext{
${ }^{208}$ Gillies, 539.

${ }^{209}$ Ibid, 540.

${ }^{210}$ Gillies, 541.
} 

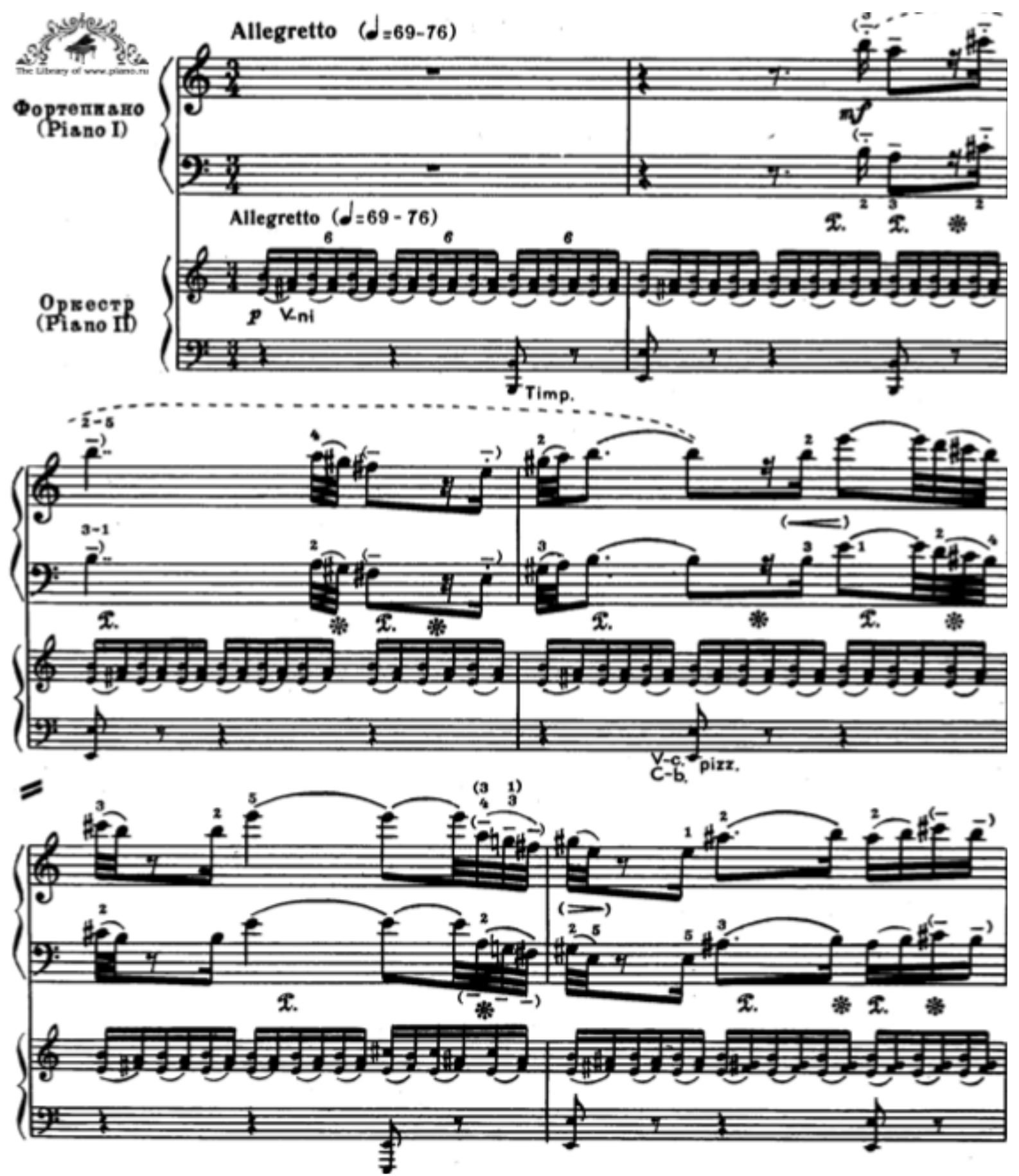

Figure 50. B. Bartók, Piano Concerto No. 3, 1st movement, mm. 1-7 $7^{211}$

211 "Main Page," IMSLP/Petrucci Music Library: Free Public Domain Sheet Music, accessed September 12, 2017, http://imslp.org/. 
This melody is heavily ornamented and gives the impression of an improvisation. Each of the bars of the opening builds a different scale or portion of a scale over the note E. The string section introduces $\mathrm{E}, \mathrm{F} \#, \mathrm{~A}$, and $\mathrm{B}$. In the second bar the piano adds $\mathrm{C} \#$, creating a pentatonic structure, until the G\# is added in measure three. The seventh scale degree, D\#, is missing for the complete major scale, but measure four supplies a D natural, which completes a Mixolydian mode. G, instead of G\#, in measure five suggests a Dorian mode, while the Lydian characteristic is introduced in measure 6 by $\mathrm{G} \#$ and $\mathrm{A \#}$. In general the movement is centered primarily in $\mathrm{E}$ Mixolydian mode and is more tertian, with simpler harmonies, than the first two concertos. ${ }^{212}$

The whole movement reveals an improvisatory quality. Bartók makes us see and hear what he is doing to help the pianist give the impression of improvisation. ${ }^{213}$ The example below shows Bartók’s technique of writing out an improvisation.
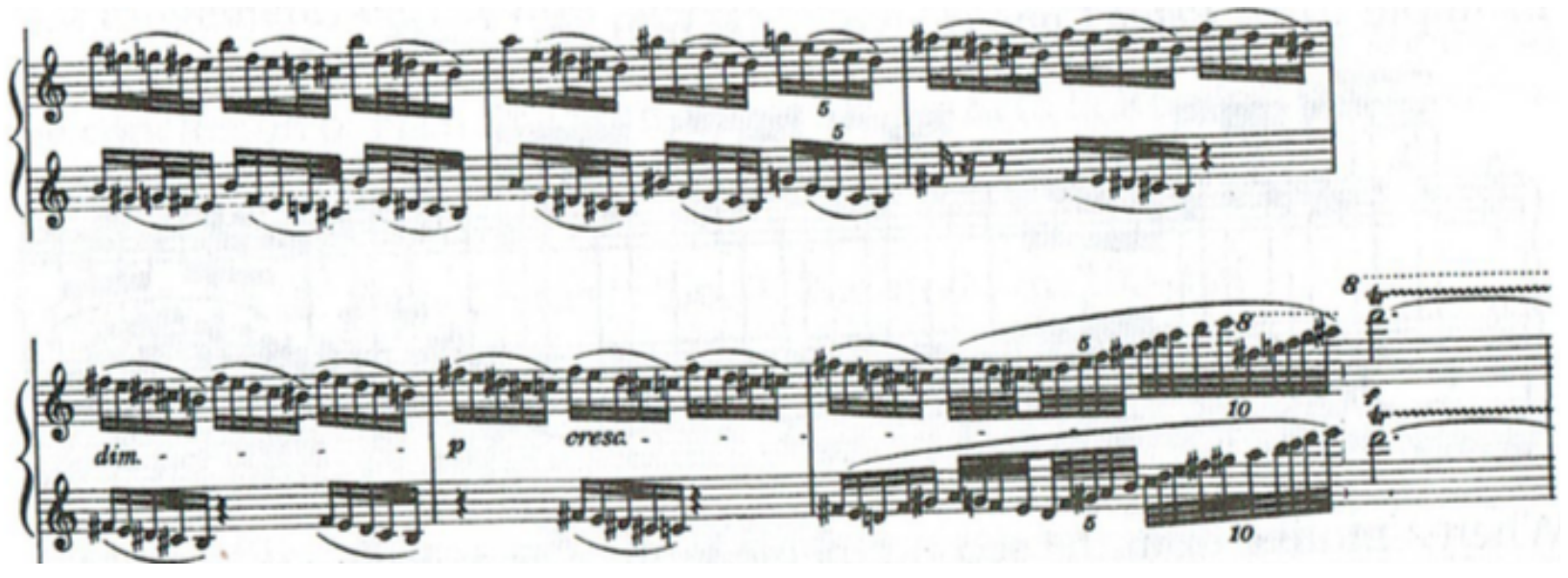

Figure 51. B. Bartók, Piano Concerto No. 3, 1st movement, mm. 13-19

The formal plan and tonal centers for this movement:

212 Gillies, 541.

${ }^{213}$ Nissman, 277.

${ }^{214}$ Ibid, 277. 


\begin{tabular}{|c|c|c|}
\hline Exposition & Development & $\underline{\text { Recapitulation }}$ \\
\hline$m m .1-11 \quad 1$ st group in $\mathrm{E}$ & $m m .75-88 \quad \mathrm{Ab}$ & $\begin{array}{l}m m .118-1271 \text { st group in } \\
\text { E }\end{array}$ \\
\hline mm. 1-17 Transition & mm. 87-98 Bb & mm. 128-136 Transition \\
\hline mm. 18-53 Bridge & mm. $99-110 \quad$ C-D-E-F\# & mm. 137-161 Bridge \\
\hline $\begin{array}{l}m m .54-672 \text { nd group in } \\
\mathrm{G}\end{array}$ & mm. 110-117 G\# & $\begin{array}{l}m m .162-174 \text { 2nd group } \\
\text { in } \mathrm{E}\end{array}$ \\
\hline mm. 68-47 Closing in G & & mm. $175-187$ Closing in $\mathrm{E}$ \\
\hline
\end{tabular}

It is interesting that the key Bartók chose for the second group is a minor third above the tonic. This interval seems to be important in the movement, as the ending of the movement shows, closing as it does with two successive minor thirds in the top voice of the piano. There is another minor-third relationship in $\mathrm{mm}$. 56-58. In $\mathrm{m} .56$, the clarinet answers the piano figure in inversion and, in $\mathrm{m} .58$, the piano moves to $\mathrm{Bb}$.

The development section is quite short but still has the function of traditional development: it develops previous material (the first theme), provides harmonic excitement and creates a climax. It is also a section of beautiful, inventive music with asymmetrical rhythms and pentatonicism. The character of the closing section is similar to the exposition, but beginning in m. 180 the major-third dialogue between piano and woodwinds is extended. A solo flute

\footnotetext{
${ }^{215}$ Alice Terese. Stewart, “The Three Piano Concertos of Béla Bartók,” (Master's thesis, Texas University,1973), 64.
} 
introduces the opening theme, and the pianissimo thirds in the piano bring the movement to a close, without a coda.

\section{Second Movement (Adagio religioso)}

This movement is the central focus of the work, containing some of the most unique writing of the entire concerto. ${ }^{216}$ In Bartók's previous piano concertos there is a very big contrast in mood and orchestration between the first and second movements, but here the second movement is rather connected to the preceding movement. It is titled Adagio religioso, which Bartók had never used before as an indication, but later also added to the incomplete Viola Concerto.

The world "religioso" gives a very spiritual meaning to the movement. He knew that he was near the end of his life and probably wanted to create something very special. Indeed, this movement has a unique beauty. The piano and orchestra alternate peacefully, the night music is bright and cheerful and the result is profound inner contentment.

There is an inner sadness which is eloquently described in Nicky Loseff's dissertation:

Here all is subjected to a merciless brilliance which lights up an increasingly painful nostalgia and a crumbling of hopes, expressed through the use of an ever more overt late Romantic harmony.

Loseff also uses the word "anguish" to describe the atmosphere of the movement. ${ }^{218}$

Indeed, Bartók's nostalgia for his abandoned homeland is obvious. Tension clearly appears through the changes of lengths, rhythms, and harmonies of the different chorale lines. The first three chorale lines have the same settings for the piano. The fourth line (measure 38) starts in a similar manner but expands to nine measures and introduces new rhythms. The fifth and final

\footnotetext{
${ }^{216}$ Nissman, 275.

${ }^{217}$ Straus, 97.

${ }^{218}$ Ibid, 97.
} 
choral line (measures 48-56) is different from the rest, both in rhythm and harmony. The "Tristan chord" evokes the longing harmonies of Romanticism. We hear this chord in various transpositions on four occasions, before the final resolution to C Major (measures 53-54). ${ }^{219}$

This is an outline of the entire movement:

\begin{tabular}{|c|c|c|}
\hline Section A & $\underline{\text { Section B }}$ & $\underline{\text { Section A }}$ \\
\hline \multirow{2}{*}{$\begin{array}{l}m m .1-15 \text { Imitation in } \\
\text { Strings }\end{array}$} & mm. 58-67 a (Bird Calls) & \multirow{6}{*}{$\begin{array}{l}\mathrm{mm} .89-137 \text { Return of } \\
\text { chorale in woodwinds with } \\
\text { piano counterpoint }\end{array}$} \\
\hline & $m m .68-71$ b Transition & \\
\hline \multirow{4}{*}{$\begin{array}{l}m m .16-57 \text { Statement of } \\
\text { chorale by piano }\end{array}$} & $m m .72-75$ a & \\
\hline & mm. $76-78 \mathrm{~b}$ & \\
\hline & mm. 79-85 a & \\
\hline & mm. $86-88 \mathrm{~b}$ & \\
\hline
\end{tabular}

The material is presented through five-voiced imitation, where the voices enter from top to bottom at the distance of two beats, for three-measure units on $\mathrm{C}$ and $\mathrm{G}$. There is free inversion in the imitations presented in all voices. The four-measure chorale phrase introduced by the piano brings forth the true sadness. The first three chorale lines have the same settings for the piano. The fourth line (measure 38) starts in a similar manner but expands to nine measures and introduces new rhythms. The fifth and final choral line (mm. 48-56) is different from the rest, both in rhythm and harmony. Despite the anguish of the fourth and fifth phrases of the

\footnotetext{
${ }^{219}$ Gillies, 545.

${ }^{220}$ Stewart, 74
} 
chorale, the serene and meditative character of the movement remains intact. The motif with which this movement starts and to which it now returns is clearly pentatonic, a flavor which Bartók always considered a chief characteristic of ancient Hungarian folk song and a symbol of his Hungarian homeland. ${ }^{221}$

The central section is a passage of nature sounds, another example of the "night music" which he also used in the Second Piano Concerto, Fifth String Quartet, and Music for Strings, Percussion, and Celeste. This music is free of the mysterious and macabre atmosphere, but the color and texture evoke the atmospheric sounds of night. Here Bartók appears as lover of nature, using woodwinds and piano to create bird sounds and other effects. The bird calls in particular are voiced by oboe and clarinet. According to Peter Bartók, on a visit to Asheville his father transcribed birdsong in his notebook with the same precision he used for his folksong notation. The trio recalls the "Night Sounds" movement from the Out of Doors. ${ }^{222}$

\section{Third Movement (Allegro Vivace)}

The energy of the third movement is reminiscent of Allegro Barbaro. It is sparkling and full of life with a distinctive Hungarian folk rhythm: short-long, long-short; this rhythm is the "softer" variation of the Hungarian dotted rhythm identified by Bartók. The theme is a stylized folk-dance tune of Hungarian flavor. ${ }^{223}$

\footnotetext{
${ }^{221}$ Ibid, 545 .

${ }^{222}$ Ibid, 545.

${ }^{223}$ Gillies, 546.
} 


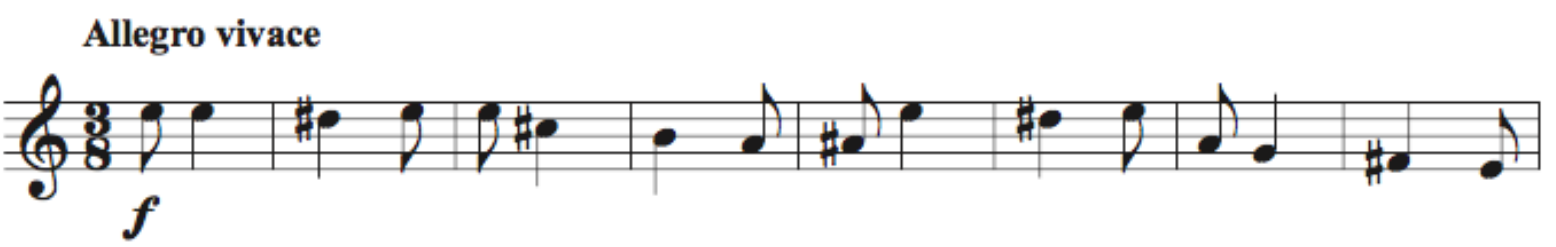

Figure 52. B. Bartók Piano Concerto No. 3, 3rd movement, main theme

This movement reveals a rondo form $(\mathrm{A}-\mathrm{T}-\mathrm{B}-\mathrm{T}-\mathrm{A}-\mathrm{T}-\mathrm{C}-\mathrm{T}-\mathrm{A}-\mathrm{Coda})$ with two complex fugues in the middle, which establish a direct relationship with the contrapuntal textures of its predecessor concertos.

\begin{tabular}{|c|c|c|c|c|}
\hline$\underline{A}$ & Transition & $\underline{B}$ & Transition & $\underline{A}$ \\
\hline $\begin{array}{c}\text { mm. } 138-203 \\
\text { in } E\end{array}$ & mm. 204-227 & $\begin{array}{c}m m .228-321 \\
\text { in C\# }\end{array}$ & mm. 321-342 & $\begin{array}{c}m m .344-375 \\
\text { in } \mathrm{E}\end{array}$ \\
\hline Transition & $\underline{C}$ & Transition & $\underline{A}$ (Expansion) & $\underline{\text { Coda }}$ \\
\hline \multirow[t]{3}{*}{ mm. 376-391 } & $\begin{array}{c}m m .392-426 \\
\text { in } \mathrm{Bb}\end{array}$ & \multirow[t]{3}{*}{ mm. 483-526 } & \multirow[t]{3}{*}{$\begin{array}{c}m m .527-641 \\
\text { in E }\end{array}$} & mm. 644-720 \\
\hline & $\begin{array}{l}m m .427-472 \\
\text { Fugue-like }\end{array}$ & & & \multirow[t]{2}{*}{$\begin{array}{c}m m .721-768 \\
\text { in } \mathrm{E}\end{array}$} \\
\hline & $\begin{array}{c}m m .473-482 \\
\text { in } \mathrm{Bb}\end{array}$ & & & \\
\hline
\end{tabular}

${ }^{224}$ Stewart, 81 
The first episode, starting in measure 228 , is a fugal introduction by the piano. In measure 392 the second episode starts a segment that sounds like a Bach Menuet. ${ }^{225}$ This musical material reminds the listener not only of folk music but also of Baroque music.

This movement has a rhythmic complexity which makes it even more authentic. The meter is $3 / 8$ but changes to $2 / 4$ in the center of the movement and $3 / 4$ in the Coda. These meter changes are characteristic of Bartók’s fast movements. Rhythmic excitement is generated through fluctuation of meter across the bar lines and duple-versus-triple subdivisions.

The last 17 measures and most of the dynamic and expressive indications are added by Tibor Serly, who was Bartók's student and friend. Bartók left these last measures unfinished at his death, in the form of a sketch. He did mark the ending Vége, which means "end" in Hungarian. The tempo indication Allegro Vivace also comes from Serly. ${ }^{226}$

The movement is lucid and relaxed even in the most complex counterpoint and aggressive fugal passages. Complexity is replaced here by simplicity with accessible piano writing. I believe economy is the focus of Bartók's final work. He removed everything and only used what was truly important and essential.

This concerto is a connection to his earlier work, a turning back both to the beginning of his activities when he was an ethnomusicologist, and also to Neoclassicism and traditionalism. Simplicity and lightness are outstanding here. To those who had never understood Bartók's music, this new simplicity was dismissed as the sad product of his weakened condition. Something similar had happened during the previous century, when Beethoven's visionary

\footnotetext{
${ }^{225}$ Gillies, 546 .

${ }^{226}$ Gillies, 547.
} 
harmonies were blamed on his deafness. This is a spectacularly beautiful concerto-greatly

lyrical, sometimes prayerful, often mysterious, and appealingly naturalistic.

Nicky Loseff offers a perceptive opinion about this piece:

In this concerto he surrenders, "parting in peace" not only from his wife, Ditta, and his own micro-cosmos, but from music itself. We read this concerto as weak, "one sided" or "feminine" at our peril: the yin-yang equilibrium is as ever there, as the energy of the finale shows, but Bartók has taken his leave through the medium of light, not dark, and through thrift and transparency rather than the sonic abundance (far greater dissonance) of the earlier concertos.

${ }^{227}$ Nicky Lossef, "The Piano Concertos and Sonata for Two Pianos and Percussion." The Cambridge Companion to Bartók: 118-32. doi:10.1017/ccol9780521660105.010. 


\section{Chapter VII}

\section{Kodály}

\section{About the composer}

Born in 1881, in Kecskemet, Hungary, Zoltán Kodály began studying violin, piano, and cello at a young age. He had a fascination with choral music and joined the cathedral choir. This early experience influenced Kodály and he felt choral singing was important for musicians. In 1900, he enrolled at the Liszt Academy of Music in Budapest, where he studied composition.

In 1905, Kodály started collecting folk songs in the Hungarian countryside, recording them on phonograph cylinders. Around this time he met Béla Bartók and the two became lifelong friends; they also introduced each other to some of the methods involved in folk song collecting.

So little of written old Hungarian music has survived that the history of Hungarian music cannot be built up without a thorough knowledge of folk music. It is known that folk language has many similarities with the ancient language of a people. In the same way, folk music must for us replace the remains of our old music. Thus from a musical point of view, it means more to us than to those people that developed their own musical style centuries ago. ${ }^{229}$

Inspired after collecting folk music, Kodály wrote his $\mathrm{PhD}$ thesis with the title Strophic Construction in Hungarian Folk Song; he later taught theory and composition at the Liszt

\footnotetext{
${ }^{228}$ Ong, 4-6.

${ }^{229}$ Bence Szabolcsi and Ágoston Ráfael Toth, Zenei Lexikon. A Zenetörténet és Zenetudomány Enciklopédiája ... Szerkesztették: Szabolcsi Bence és Tóth Aladár, etc. (Budapest, 1930), 64.
} 
Academy. ${ }^{230}$

His first major success as a composer was in 1923, with Psalmus Hungaricus. This commission celebrated the $50^{\text {th }}$ anniversary of the union of Buda and Pest (which historically had been separate cities) into Budapest. The commission and the success of the piece established Kodály both as a national and cultural leader and also as a figure of international standing. ${ }^{231}$

In 1925 he became interested in the music education of children. It should be noted that Kodály created a new project but the actual teaching method was developed by his colleagues, talented students, and friends.The Kodály Method incorporates rhythm syllables, where note values are assigned specific syllables that express their durations. Another important part of the Method is the use of hand signs. These hand signals provide a visual aid, showing particular tonal function, but also allow children to see the height or depth of the pitch. ${ }^{232}$

In 1945, Kodály became Director of the Liszt Academy and continued to accumulate titles: President of Hungarian Arts Council, President of International Folk Music Council, Honorary President of the International Society for Music Education, and Order of the Hungarian People's Republic. ${ }^{233}$

\section{Dances of Marosszék.}

Kodály states that music from Dances of Marosszék represents an older continuum of folk music than the more well-known Hungarian works by Brahms and Liszt:

The famous Hungarian Dances from Brahms's time are the expression of

\footnotetext{
${ }^{230}$ Ong, 7.

${ }^{231}$ Ibid, 9.

232 "Kodály Method," Wikipedia, March 10, 2017, accessed April 11, 2017, https://en.wikipedia.org/wiki/Kod\%C3\%A1ly_Method.

${ }^{233}$ Ong, 10.
} 
the spirit of the Hungarian city about 1860 , being mostly composed by native musicians of this epoch. The Marosszék dances are of a former period, suggestive of the image of Transylvania, once called "Fairyland." 234

Kodály first composed the piano version (1927) and then the orchestral rendition (1930). Marosszék is a region of Transylvania, today called Mures County; it is also where I spent my childhood. Kodály collected the tunes from this region, and some of the sources of these songs date back several centuries.

Marosszéki is a pair dance, also called "crossbred," "turning," or "shuttling." During the dance the man keeps passing the woman from one of his arms to the other, turning her around in front of him; this explains the expressions "turning" or "shuttling." 235

The melodies in this piece come from two main sources:

1. Strictly instrumental dance music with melodies transcribed from Marosszék. Some melodies are transcribed from the region of Marosszék, while others are based on melodies from the wider Transylvanian area. ${ }^{236}$

2. Melodies from Vietorisz Virginal Codex dating from 1680. The codex contains Hungarian instrumental music by anonymous collectors. These songs are characterized by flexible, finely shaded melodies with a tendency to create wider and looser forms. At the same time, rhythms are also flexible and complex. ${ }^{237}$

The compositional style of Dances of Marosszék is voice-oriented, with melody and lyricism being most important. One can clearly hear the predilection for melancholy and

\footnotetext{
${ }^{234}$ Zoltán Kodály, Marosszéki táncok = Marosszéker Tänze = Dances of Marosszék (Wien: Universal-Edition, 1930), 1.

${ }^{235}$ Ong, 58.

${ }^{236}$ Ong, 53.

${ }^{237}$ Ong, 53.
} 
uncertainty. The folk influences are obvious, including: pentatonic Hungarian and modal scales; rich ornamentation; and use of a slow section featuring rubato melody types, as well as fast ostinato rhythmic figures derived from folk dances.

The influence of Liszt is also clearly evident. The heroic main theme is reminiscent of Liszt's Rhapsodies and his improvisatory style. The virtuosic elements (fast octaves in the Coda marked with dynamic sign $f f$, accented chords, and tremolos creating suspension) are also Liszt-influenced.

The different modes create a rich timbre which is reminiscent of Debussy. For example, the opening theme conveys a colorful exoticism.

The form is a seven-part Rondo with Coda, where the main melody is linked to two sources: the previously mentioned Vietorisz Virginal Codex and a folk song from Zenei Lexicon (Encyclopedia of Music), collected by Béla Vikár. ${ }^{238}$

Kodály copies the original melody but changes the meter (4/4 instead of 2/4); he also leaves out an embellishment in in the second part of the melody. He states that, While embellishments are a common characteristic found in folk music, they do not have to be observed as accurately as the primary portion of the tune. ${ }^{239}$

Indeed, in folk music it is reasonable to make changes by altering or excluding certain embellishments. ${ }^{240}$

\footnotetext{
${ }^{238}$ Ibid, 53.

${ }^{239}$ Ibid, 54.

${ }^{240}$ Ibid, 54.
} 


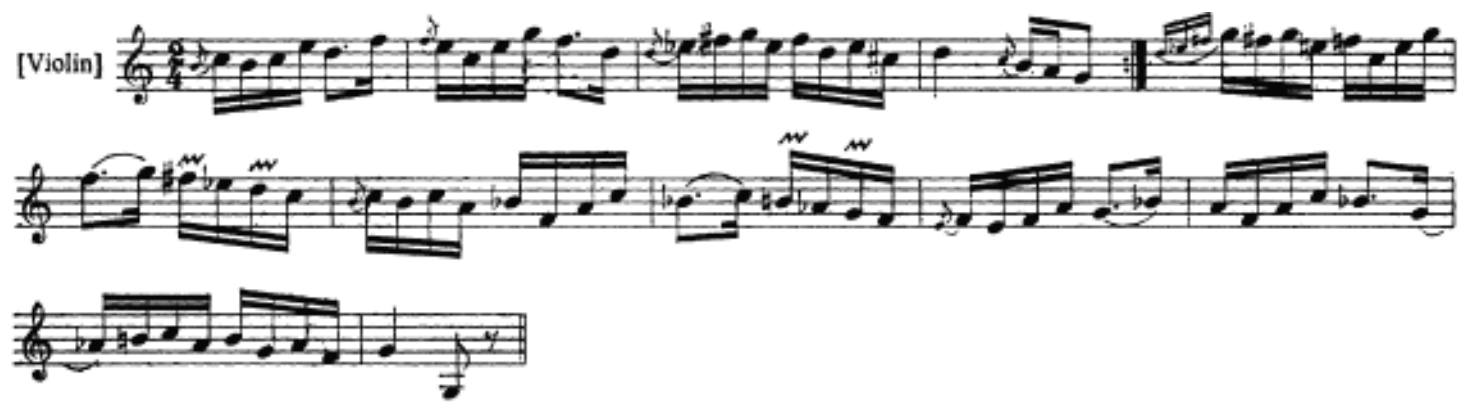

Figure 53. Original melody collected by Kodály in Csík County in $\mathbf{1 9 1 0}^{241}$
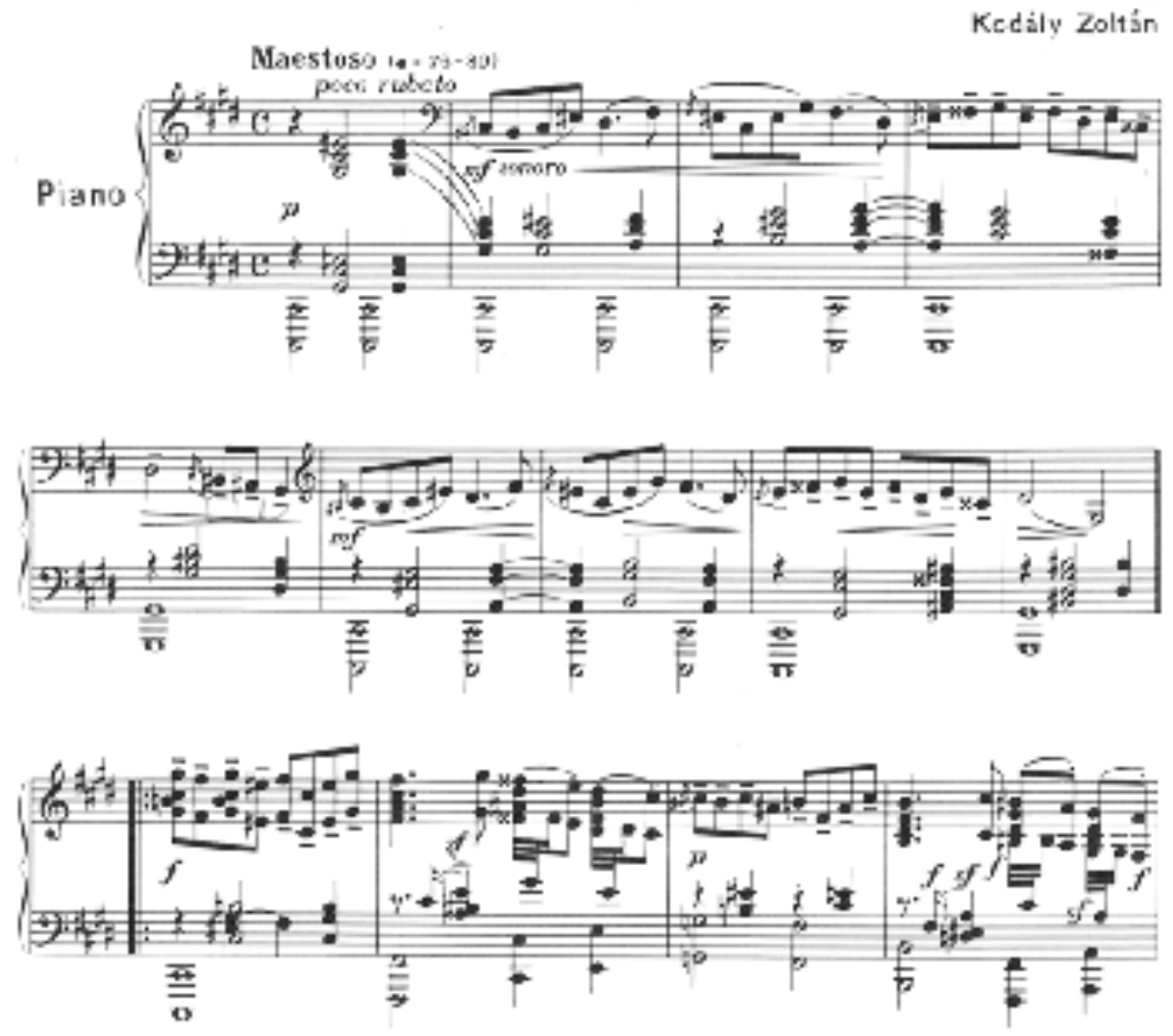

Figure 54. Z. Kodály, Dances of Marosszék , mm. 1-13 242

The first episode is based on a melody collected by Béla Vikár, who first heard the melody played by a Gypsy clarinetist. Here Kodály makes a variation of the original melody. ${ }^{243}$

\footnotetext{
${ }^{241}$ Ibid, 54.

${ }^{242}$ Zoltán Kodály, Marosszéki táncok= Marosszéker Tänze = Dances of Marosszék : zongorára = piano solo (Wien: Universal Edition, 1982).

${ }^{243}$ Ong 56.
} 

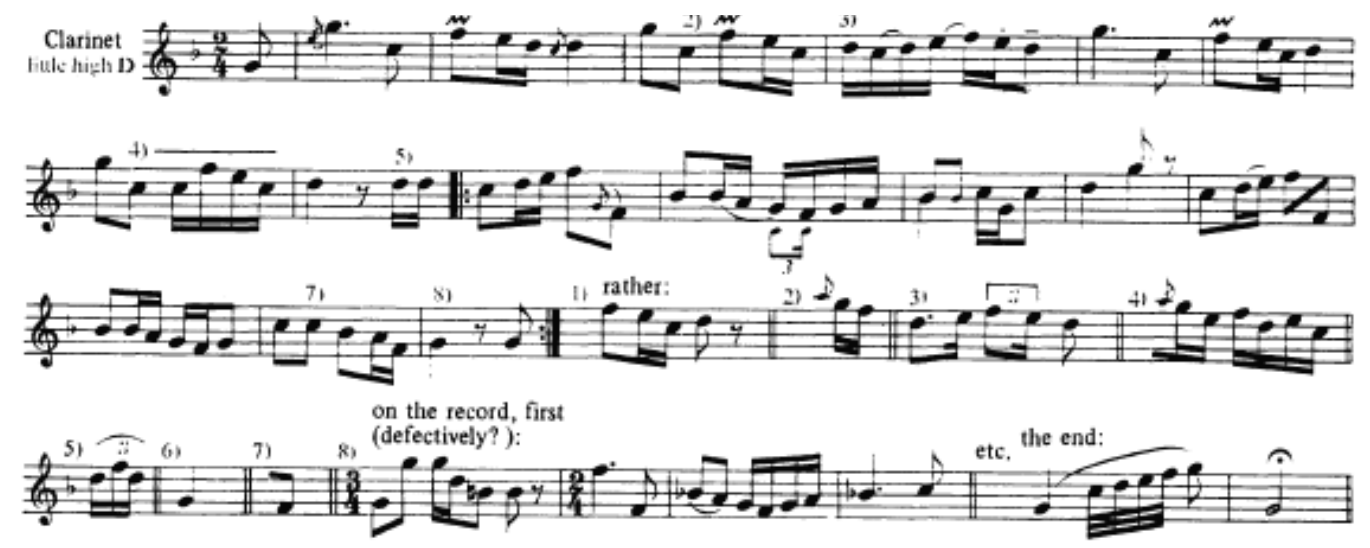

\section{Figure 55. Original melody first recorded by Béla Vikár, transcribed by Kodály ${ }^{244}$}
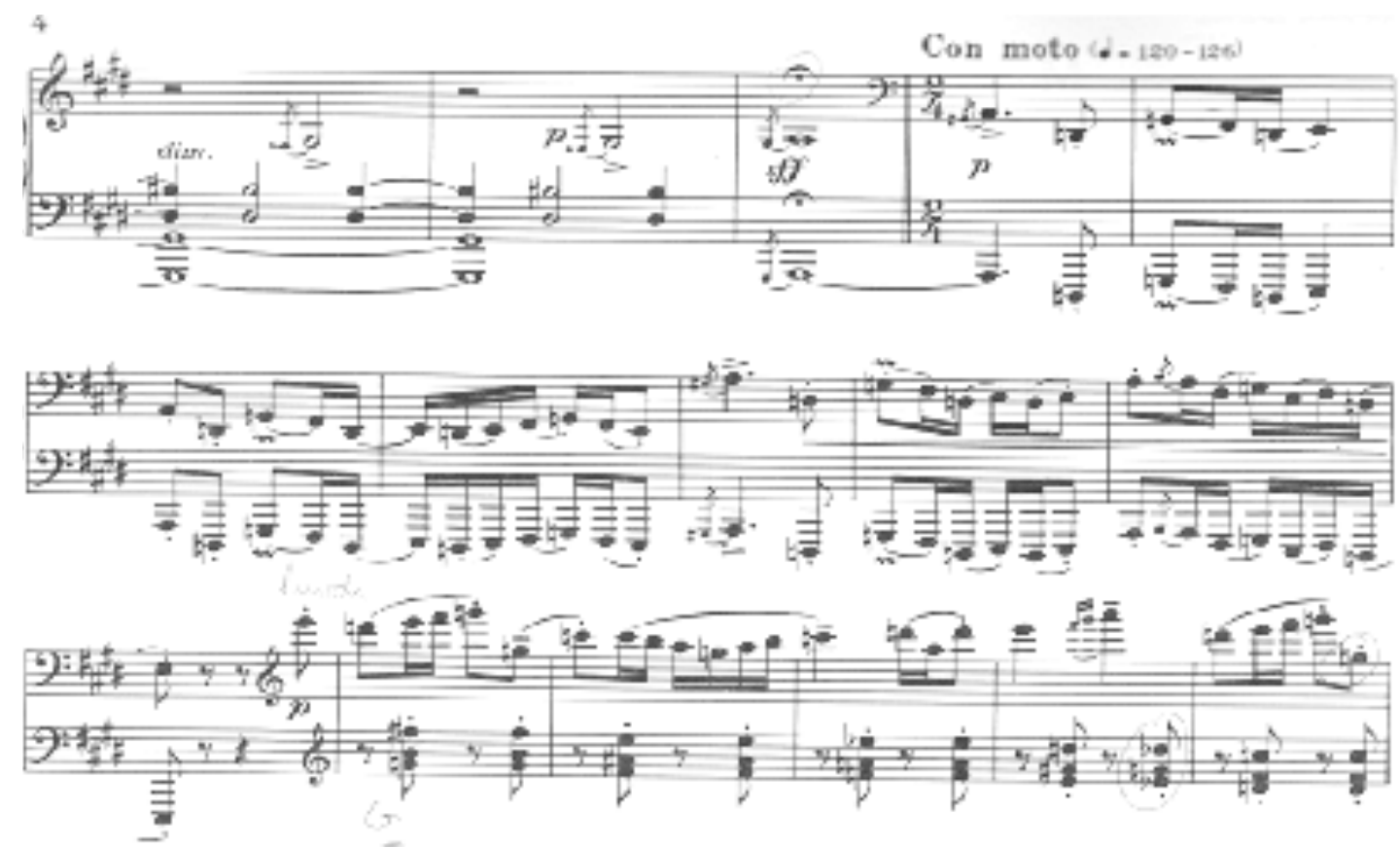

Figure 56. Z. Kodály, Dances of Marosszék, mm. 18-33 ${ }^{245}$

Kodály transformed different parts of the melody; these alterations can best be represented by a visual comparison of the original melody on the clarinet with the melody used in the Dances of

\footnotetext{
${ }^{244}$ Ong, 57.

${ }^{245}$ Zoltán Kodály, Marosszéki táncok = Marosszéker Tänze = Dances of Marosszék : zongorára = piano solo (Wien: Universal Edition, 1982).
} 
Marosszék seen above.

The key structure of the first section reveals characteristics of both the Hungarian scale and more modern scale structures. The piece is rooted in D major, but modulates briefly to D harmonic minor in the fourth bar.

The second episode is a single melody over syncopated accompaniment. This part has a free pulse with numerous embellishments; it also reminds the listener of Old-style folk music with pentatonic scales and quartal harmonies. It avoids conventional harmonic progression, with phrases not remaining tonal. According to ethnomusicologist László Eősze, this melody is an example of the parlando style, in which "popular, improvised music of the shepherd's pipe is transformed into art music of the highest quality." 246

Figure 57 shows another melody collected by Vikár and transcribed by Kodály. In its original version, this melody also features the high clarinet. ${ }^{247}$

${ }^{246}$ Ong, 60.

${ }^{247}$ Ibid, 60 . 

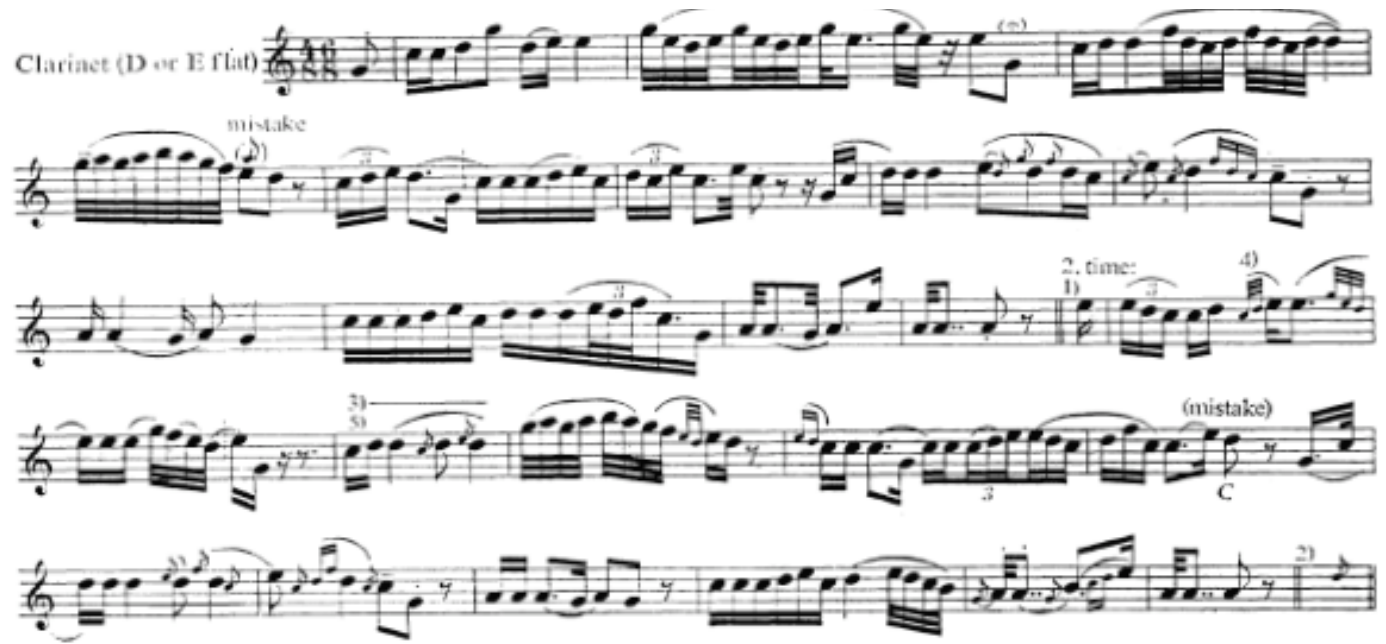

Figure 57. Original melody transcribed by Kodály ${ }^{248}$
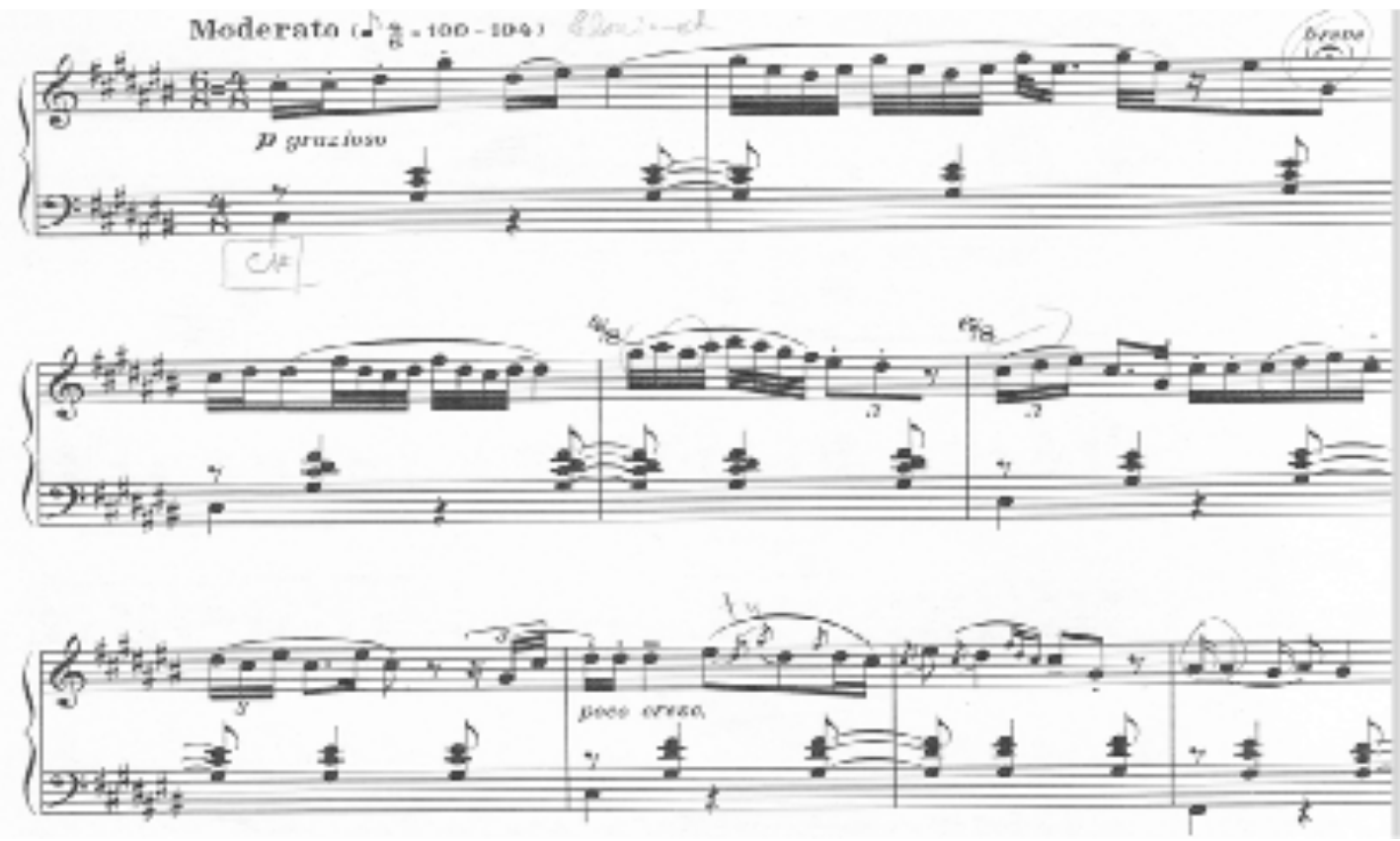

Figure 58. Z. Kodály, Dances of Marosszék, mm. 100-109 249

${ }^{248}$ Ong, 61.

${ }^{249}$ Zoltán Kodály, Marosszéki táncok $=$ Marosszéker Tänze $=$ Dances of Marosszék $:$ zongorára $=$ piano solo (Wien: Universal Edition, 1982). 
This melody has a free pulse and numerous embellishments, undoubtedly leading to challenges for the transcriber. At times, it seems reminiscent of the second movement of Bartók's Romanian Folk Dances, where the solo piccolo plays an extensive, embellished melody over a consistently monotonous accompaniment. Dotted rhythms appear constantly here; they are characteristic of Hungarian style and become an integral part of Kodály’s later Dances of Galánta. $^{250}$

The third Episode is a fast dance based on a melody collected by Kodály in 1912. The performer was a peasant flute player from Csík County, Transylvania. ${ }^{251}$
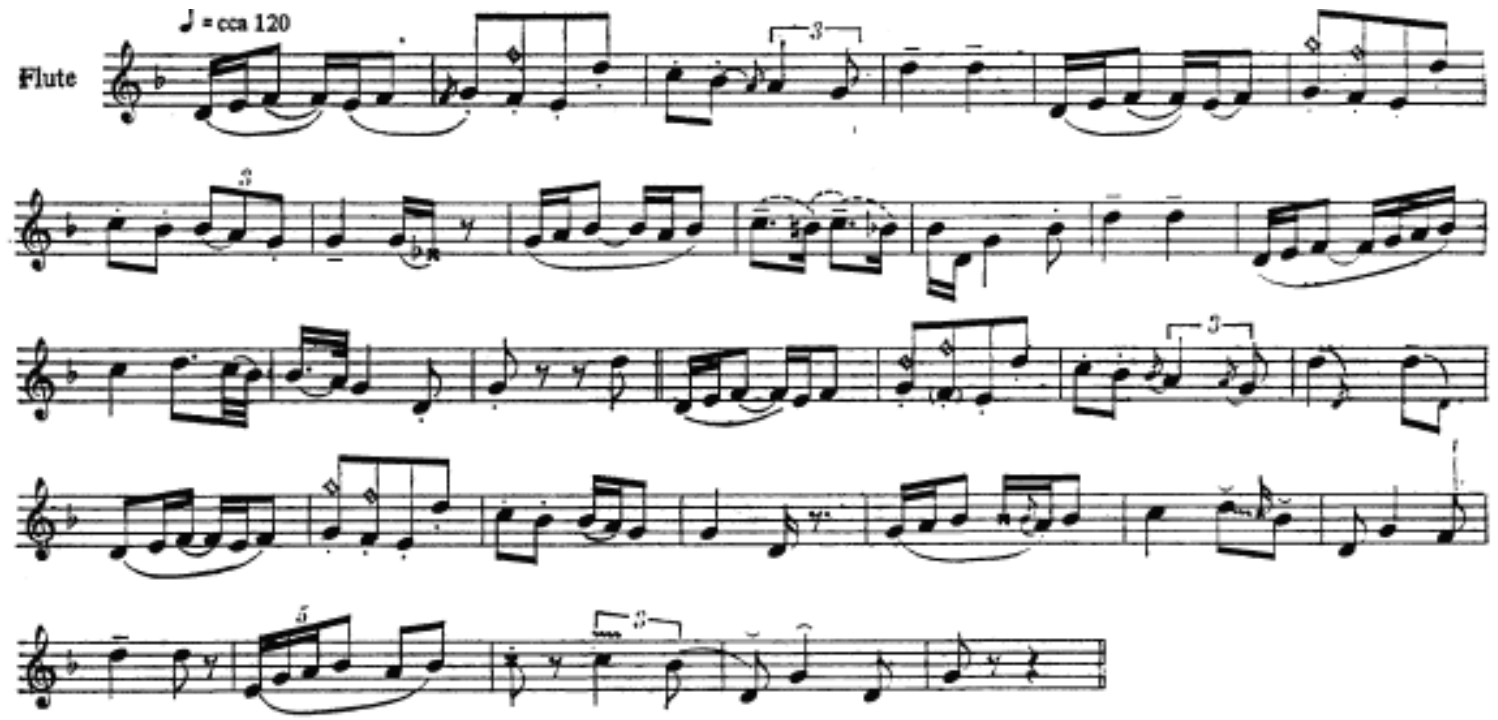

Figure 59. Original melody collected and recorded by Kodály in $1912^{252}$

${ }^{250}$ Ong, 63.

251 Ibid, 63.

${ }^{252}$ Ibid, 64. 

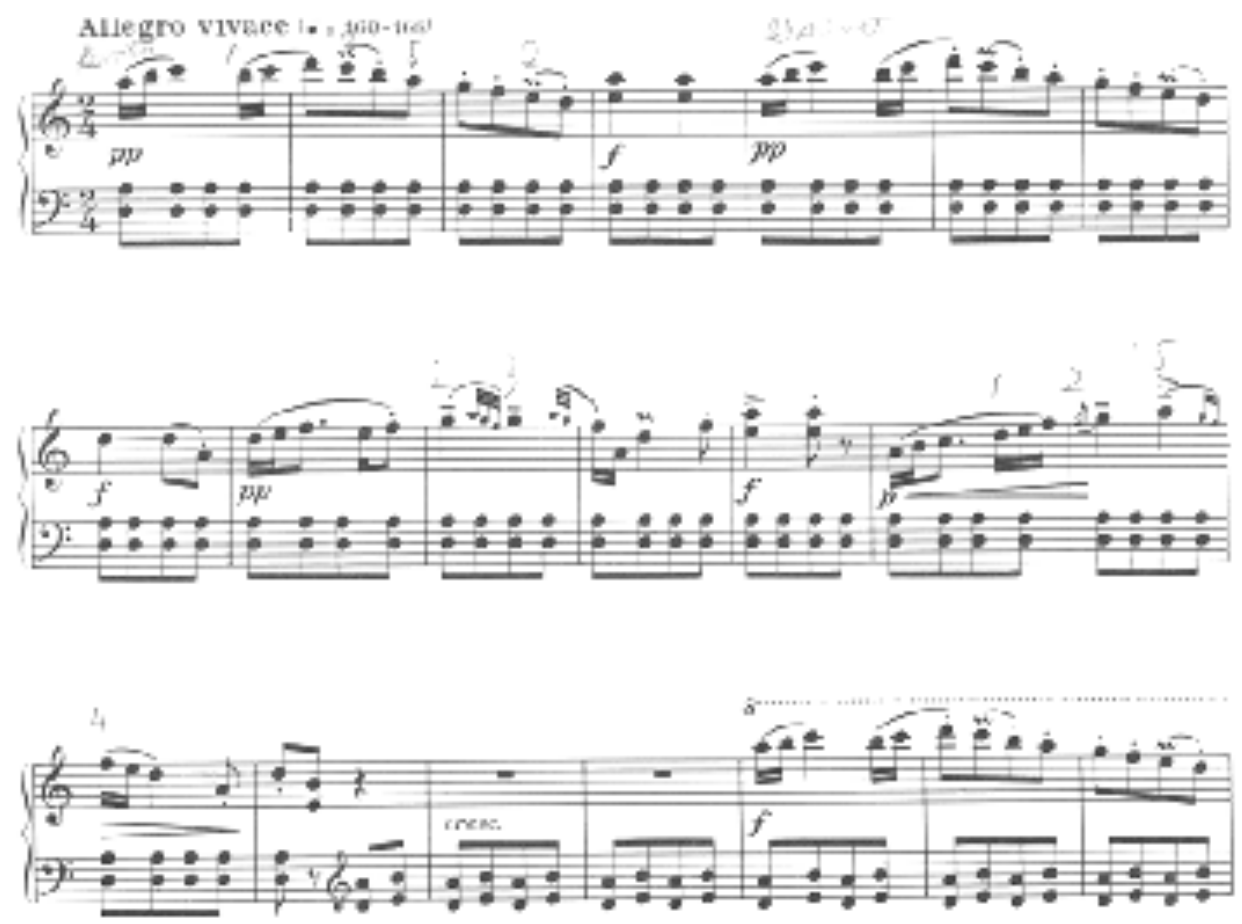

Figure 60. Z. Kodály Dances of Marosszék, mm. 174-193

Among all the melodies implemented into the work, this has the most alterations from the original melody. For example, Kodály transposes several notes from the original melody up an octave to fit the overarching contour of the melody more smoothly, rather than preserving the shifts in register. Other changes include eliminating some of the more complicated rhythms, as this particular section of the piece is much faster (quarter note $=160-168 \mathrm{bpm}$, compared to the original melody where a quarter note $=120 \mathrm{bpm})$. At times, it seems as if Kodály substituted compound meters with grace notes to embellish longer note values. This is most likely done so that the piece correlates with the other melodies that have singable core melodies with improvisatory ornamentation..$^{254}$

\footnotetext{
${ }^{253}$ Zoltán Kodály, Marosszéki táncok = Marosszéker Tänze = Dances of Marosszék:zongorára = piano solo (Wien: Universal Edition, 1982).

${ }^{254}$ Ong, 64.
} 
The Coda has its own melody (collected by Béla Vikár), but not enough context to be considered a full section. It sounds as if the Coda repeats the same melody in different variants, as if intended for different instruments. We also find some unusual harmonies with unresolved dissonances. ${ }^{255}$ The repetitions join a long crescendo, reaching all the way to $f f f$, to achieve a climactic and victorious ending.

Overall the harmonic language and voicing give each section a complex identity. Rather than copying folk-music idioms, Kodály alters the melody to fit within modern music standards but keeps the flavor of folk music.

This piece is a great treasure to me and creates a sense of nostalgia for the land and music of my childhood. This intense personal connection to the music contributes to a unique experience for me while playing this piece.

I feel truly inspired to keep learning more about Kodály’s music. His music is an imaginary bridge which connects the past and future. For me, it is this sense of connection which gives this Hungarian music its sophistication, its depth, and its immortality.

\footnotetext{
${ }^{255}$ Ong, 66-67.
} 


\section{Chapter VIII}

\section{Conclusion}

There are fascinating connections between these four composers. Dohnányi came under the influence of Liszt by studying with Liszt's pupil, Istvan Thoman. Dohnányi was also familiar with Kodály and Bartók from the Hungarian Academy. While Bartók initially came to Dohnányi to receive piano lessons, the two artists developed a deep friendship. Dohnányi appreciated and admired Bartók. "Even if there might be something I disapproved in Bartók’s music," he used to say, "and even if in some ways he acted somewhat strangely, I always acknowledged that he had the most sympathetic character and that he was the most honest and sincere man I have ever known." 256

Bartók and Dohnányi experienced similar influences in their musical development, but as composers they grew in opposite directions. Dohnányi continued to expand his piano writing within the Romantic tradition and generally stayed within the framework of $19^{\text {th }}$-century style. Bartók, in his early works through 1910, also went through an imitative period, but finally found his own path. ${ }^{257}$

After 1910, he seemed to know instinctively the direction he had to travel, never making any radical departures or detours. ${ }^{258}$ The Lisztian traces in Bartók's music are possibly from Dohnányi. In an article entitled "The Music of Liszt and Contemporary Audiences," written in

\footnotetext{
${ }^{256}$ Dohnányi and Grymes, 47.

${ }^{257}$ Nissman, 1.

${ }^{258}$ Ibid, 1.
} 
1911, he spoke very highly of the later Liszt compositions, giving special praise to the Liszt compositions connected with the Faust theme, including the Faust Symphony, Sonata in B minor, and Dance Macabre. ${ }^{259}$

In his inaugural lecture at the Hungarian Academy of Sciences in 1936, Bartók declared that traces of Liszt's legacy can be discovered with certainty in recent Hungarian compositions. He was undoubtedly including himself among those who were under the influence of Liszt. However, the folk melodies that Bartók used, unlike Liszt's verbunkos melodies, were not based on major or minor scales with occasional uses of the verbunkos scale. ${ }^{260}$ These melodies — discovered by collecting samples in the field with staff paper and a dictaphone-were instead based on ancient scales—Phrygian, Aeolian, Dorian, Mixolydian, and Pentatonic scales. Clearly, Bartók's transcriptions are entirely folk song based, while Liszt's transcriptions retain less folk music. Liszt's folk music is what has been retained in the transcultural context of verbunkos.

Why was collecting native folk music so important to Bartók and Kodály? The answer tells us much about their music. Bartók states:

Collecting gives you an opportunity to sink so deeply into the source of your nation's musical treasure that you become part of it. You mingle with your heritage until it becomes, like the language itself, your very own. Writers, composers, poets alike, and of course painters too. ${ }^{261}$

\footnotetext{
259 "ProQuest Subject Index - Music at JAMES_MADISON_UNIVERSITY." Accessed April 1, 2017.http://www.bing.com/cr?IG=CE088B31632D42ABA4085E7D94339998\&CID=0307D522BAA862 620A27DF75BB996386\&rd=1\&h=rCGW6bX8nOujUwPunzD6RtG5z-tYuWn05o-R4slFUmg\&v=1\&r=h ttp $\% 3 \mathrm{a} \% 2 \mathrm{f} \% 2$ fgradworks.proquest.com $\% 2$ fbrowse $\% 2$ fJAMES MADISON UNIVERSITY $\% 2 \mathrm{fMusic}$.ht ml\&p=DevEx,5127.14.

${ }^{260}$ Ibid.

${ }^{261}$ Fassett, 192.
} 
Kodály believed that the collection and study of folk material was essential to the foundations of the Hungarian school of traditions. Unlike Bartók, Kodály confined his studies exclusively to Hungarian folklore. Kodály's musical language is specifically Hungarian: the melody is based on the ancient Magyar pentatonic scale, and the rhythm schema derived from the galliard, a Renaissance court dance in triple meter mixed with Hungarian dotted rhythm. ${ }^{262} \mathrm{He}$ followed the Psalmus Hungaricus with such unique works as Hary János (1929), Dances of Marosszék (1930), Dances from Galánta (1933), and several other important songs and choral works. ${ }^{263}$ All of these reflected the spirit of Hungarian folk music to such high degree that Bartók himself mentioned Kodály as "the best Hungarian musician...the greatest Hungarian teacher-composer." ${ }^{264}$

Bartók, however, expanded his research and also explored music of other countries. He became fascinated with the "Mixed Class" Hungarian material, collecting thousands of vocal and instrumental melodies from Hungarian villages inhabited by Slovak, Romanian, Ukrainian, Bulgarian, and Yugoslav peasants. He even began studying music from North Africa, as well as the ballads from West Virginia during his residence at Columbia University. ${ }^{265}$ Every musical element that Bartók respected is found in folk music: clarity, economy, and directness. The emotionalism from the previous century which was associated with the Gypsies was completely missing. This simplicity of melody attracted Bartók to folk material, and the true key to understanding his music is the sense of melodic lines. While in New York during the year before his death, Bartók stated:

\footnotetext{
${ }^{262}$ Suchoff, Béla Bartók; A Celebration, 241.

${ }^{263} \mathrm{Ibid}, 243$.

${ }^{264}$ Ibid, 243.

${ }^{265}$ Ibid, 241.
} 
Here are two of Hungary's contemporary composers who have gained an international reputation, Zoltan Kodály and myself. Although we have a common outlook upon rural music and its part in the development of higher art music, there is a very marked difference in our works. Each of us has developed his own individual style, despite the common sources which were used... Kodály studied and uses as a source, Hungarian rural music almost exclusively, whereas I extended my interest and love also to folk music of the neighboring Eastern European people and ventured even into Arabic and Turkish territories for research work...Apart from the great lessons we acquired from the classics, we learned most from those uneducated, illiterate peasants who faithfully kept their great musical inheritance and even created, in a so-to-speak mysterious way, New Styles. ${ }^{266}$

The two composers, deeply rooted in their national idiom, became lifelong friends. No wonder, since they started working together in 1905, collecting songs in the Hungarian villages. Bartók’s wife, Ditta, mentions:

So often when Béla talks about Kodály, he is really talking about himself too, in a way. Their friendship was strong and vital, Kodály being one of the very few Béla really calls a friend. ${ }^{267}$

It is somehow unfair to say that Liszt's music is "not as Hungarian" as that of the two ethnomusicologists. Both Bartók and Kodály were native Hungarian speakers, and clearly they knew more than anyone else about Hungarian music. Liszt, on the other hand, by not knowing the language, was captured by a different Hungarian style which was "in fashion" at that time. One must also consider that Liszt lived in a much earlier period; he was born in 1811, when none of the ethnomusicological work had yet been done. Still, he was the first composer to write in a truly Hungarian style and he had great influence on the music of Dohnányi, Bartók, and Kodály. Dohnányi was born in 1877, some sixty years later than Liszt. In 1890, Béla Vikár started

\footnotetext{
${ }^{266}$ Suchoff, Béla Bartók: A Celebration, 244-245.

${ }^{267}$ Fassett, 116.
} 
collecting folk songs, and the beginning of the 20th century became the "golden age" of Hungarian folk music collecting. Still one can state that Dohnányi followed the path of Liszt, even though he knew more about Hungarian music. The Variations on a Hungarian Folk Song is not as nationalistic as one might expect. Here, the old-style Hungarian folk song is transformed into showy piano music, liberally spiced with Gypsy elements.

Considering all this, the most important relationship is that all four composers contributed significantly to their nation and helped to spread the beauty of Hungarian music, which will surely endure in the history of music. It is fortunate that they included a language within the music which doesn't need translation. Of course the effect is different for listeners from another nation; but it can arouse the same feelings, making it somehow universal.

Truly, they all deserve appreciation, because they found the treasure within the simplest music of peasants and Gypsies, and because they could bring it forward it to the rest of the population, enriching us all. 


\section{Bibliography}

A Dalok Oldala. Accessed October 15, 2017. http://mek.oszk.hu/05700/05702/html/a dalok.htm.

Bárdos, Lajos. 101 Magyar Népdal. Budapest: Magyar Cserkészszövetség, 1942.

Baritz, Moses. "Liszt's Hungarian Rhapsodies." The Musical Times 73, no. 1073 (1932): 608. doi:10.2307/918286.

Bartók, Béla. Hungarian Folk Music. New York: AMS Press, 1981.

Bartók, Béla, and M. D. Calvocoressi. Hungarian Folk Music. New York, AMS Press, 1981.

Bartók, Béla, Benjamin Suchoff, Zoltán Kodály, and M. D. Calvocoressi. The Hungarian Folk Song. Albany: State University of New York Press, 1981.

Beaufort, Raphaël Ledos de. Franz Liszt: The Story of His Life. Boston: O. Ditson \& Co., 1887.

Bellman, Jonathan. The Style Hongrois in the Music of Western Europe. Boston: Northeastern U Press, 1993.

Dohnányi, Ilona Von, and James A. Grymes. Ernst von Dohnányi: A Song of Life.

Bloomington: Indiana Univ. Press, 2002.

Eremiášová, Michaela. "Fourteen Bagatelles for Piano op. 6: no. I, III, IV, V, VI, VIII, and XI." PhD diss., University of Rochester, New York 2011.

Eösze, László, and Barna Balogh. Zoltán Kodály: His Life and Work. Budapest: Corvina Press, 1971.

Franz, Liszt. (n.d.). Retrieved April 09, 2017, from

https://www.britannica.com/biography/Franz-Liszt.

Gillies, Malcolm. The Bartók Companion. Portland, Or.: Amadeus Press, 1994.

Gombosi, Otto, and Béla Bartók. "Third Piano Concerto”. Notes 4, no. 4 (1947): 479. doi: $10.2307 / 889773$. 
Gooley, Dana A. The Virtuoso Liszt. Cambridge: Cambridge University Press, 2009.

Grymes, James A. Perspectives on Ernst von Dohnányi. Lanham, Md.: Scarecrow Press, 2005.

Hooker, Lynn M. "From Gypsies to Peasants. Redefining Hungarian Music from Liszt to Bartók", 2013, 95-153. doi:10.1093/acprof:oso/9780199739592.003.0003.

Járdányi, Pál, "Experiences and Results in Systematizing Hungarian Folk-Songs." Studia Musicologica Academiae Scientiarum Hungaricae 7, no. 1/4 (1965): 287. doi:10.2307/901435.

Frigyesi, Judit. Béla Bartók and Turn of the Century Budapest. Berkeley: University of California Press, 1998.

Fassett, Agatha. The Naked Face of Genius: Béla Bartók's American Years. Boston: Cambridge Press, 1958.

Full text of "Gypsy and Oriental Music". Accessed April 25, 2017.

http://archive.org/stream/jstor-534723/534723_djvu.txt.

Huneker, James. Franz Liszt. Place of publication not identified: Theclassics Us, 2013.

Hooker, Lynn M. Redefining Hungarian Music from Liszt to Bartók. New York: Oxford University Press, 2014.

Kodály, Zoltán, Lili Halápy, and Fred Macnicol. The Selected Writings of Zoltán Kodály. Budapest: Corvina Press, 1974.

"Kodály Method." Wikipedia. March 10, 2017. Accessed April 11, 2017. https://en.wikipedia.org/wiki/Kod\%C3\%A1ly_Method.

Kodály, Zoltán. Marosszéki táncok $=$ Marosszéker Tänze $=$ Dances of Marosszék $:$ zongorára $=$ piano solo. Wien: Universal Edition, 1982.

Kodály, Zoltán: A Hungarian Musician. Westport, CT: Greenwood Press, 1976.

Lee, Yu-Young. "Béla Bartók's Eight Hungarian Folk Songs for Voice and Piano: Vocal Style as Elaborated by Harmonic, Melodic, and Text Factors". PhD diss., 2006.

Leach, J. (1972). “The Cimbalom”. Music and Letters, LIII(2), 134-142.

doi:10.1093/ml/liii.2.134 
Losseff, Nicky. "The Piano Concertos and Sonata for Two Pianos and Percussion". The Cambridge Companion to Bartók: 118-32. doi:10.1017/ccol9780521660105.010.

"Magyar Rapszódiák." Wikipedia. February 19, 2017. Accessed April 01, 2017. https://hu.wikipedia.org/wiki/Magyar rapsz\%C3\%B3di\%C3\%A1k.

"Main Page." IMSLP/Petrucci Music Library: Free Public Domain Sheet Music. Accessed September 12, 2017. http://imslp.org/.

Mintz, George Jacob. Textural Patterns in the Solo Piano Music of Ernst von Dohnányi. Tallahassee, FL: Mintz, 1976.

Nissman, Barbara. Bartók and the Piano: A Performer's View. Lanham, MD: Scarecrow Press, 2002.

Paksa, Katalin. Line Starting Ornaments in the Hungarian Folk Song. Budapest: Akadémiai Kiadó, 1987.

"ProQuest Subject Index - Music at JAMES_MADISON_UNIVERSITY." Accessed April 1, 2017.http://www.bing.com/cr?IG=CE088B31632D42ABA4085E7D94339998\&CID=0307D52 2BAA862620A27DF75BB996386\&rd=1\&h=rCGW6bX8nOujUwPunzD6RtG5z-tYuWn05o-R 4sIFUmg\&v=1\&r=http $\% 3 \mathrm{a} \% 2 \mathrm{f} \% 2$ fgradworks.proquest.com $\% 2$ fbrowse $\% 2 \mathrm{fJAMES}$ MADISO N_UNIVERSITY\%2fMusic.html\&p=DevEx,5127.1.

Ong, Corinne Kay. "A Historical Overview and Analysis of the Use of Hungarian Folk Music in Zoltán Kodály's Háry János Suite, Dances of Marosszék, and Dances of Galánta”. KU ScholarWorks. January 01, 1970. Accessed February 27, 2017. https: / /kuscholarworks.ku.edu/ handle/1808/8029.

"Rákóczi March." Wikipedia. March 23, 2017. Accessed April 01, 2017. https://en.wikipedia.org/wiki/R\%C3\%A1k\%C3\%B3czi March.

Rajeczky, Benjamin. Hungarian Folk Music. S.1.: Qualiton, 1980.

Szabolcsi, Bence, and Ágoston Ráfael. "A Zenetörténet és Zenetudomány Enciklopédiája” Zenei Lexikon, Budapest, 1930.

Sárosi, Bálint. Folk Music: Hungarian Musical Idiom. Budapest: Corvina, 1986.

Sarosi, Balint. "Instrumental Folk Music in Kodály's Works: The Galanta and Marosszék 
Dances”. Studia Musicologica Academiae Scientiarum Hungaricae 25, no. 1/4 (1983): 23. doi: $10.2307 / 901959$.

Sebő, Ferenc. "Vikár Béla Népzenei Gyüjtései”. Accessed April 12, 2017.

http://folkradio.hu/folkszemle/sebo_vikar/index.php.

Somfai, László. Béla Bartók: Composition, Concepts, and Autograph Sources. Berkeley, Calif.: Univ. of California Press.

Stewart, Alice Terese. “The Three Piano Concertos of Béla Bartók”. Master's thesis, Texas University, 1973.

Strajber, Zsolt. "Hungarian Peasant and Folk Music". Retrieved April 12, 2017, from http://www.indiana.edu/ iuihsl/1 thesis7.htm

Suchoff, Benjamin. Béla Bartók: A Celebration. Lanham, MD: Scarecrow Press, 2004.

Suchoff, Benjamin. Béla Bartók: Life and Work. Lanham, MD: Scarecrow Press, 2001.

Sung, Stella Cheng-Yu. Absorption of Divergent Musical Sources and Compositional Techniques into Béla Bartók's Third piano Concerto, 1991.

Tallián, Tibor. Béla Bartók: The Man and His Work. Budapest: Corvina, 1988 Young, Percy M.

Teleky, Richard. Hungarian Rhapsodies: Essays on Ethnicity, Identity, and Culture. Seattle: University of Washington Press, 1997.

Variations on a Hungarian Folksong, Op 29 - Hyperion Records - CDs, MP3 and Lossless downloads. Accessed October 24, 2017.

https://www.hyperion-records.co.uk/tw.asp?w=W15362.

Vázsonyi, Bálint, and Dohnányi Ernő. Dohnányi Ernő. Budapest: Nap, 2000. 